Patrícia de Fátima Menegoci Eugênio

\title{
Estratégias de investigação de glicoproteínas de tecidos musculares de modelos animais distróficos
}

Tese apresentada ao Instituto de Química de São Carlos da Universidade de São Paulo como parte dos requisitos para a obtenção do título de Doutor em Ciências.

Área de concentração: Quimica Analítica e Inorgânica

Orientador: Prof. Dr. Emanuel Carrilho

São Carlos

2013 


\section{Exemplar revisado}

$\mathrm{O}$ exemplar original encontra-se em acervo reservado na Biblioteca do IQSC-USP. 


\section{Agradecimentos}

Agradeço a Deus por ter me dado a oportunidade de estudar e pelas bençãos sempre concedidas.

Aos meus pais, pelo cuidado, apoio e dedicação. Aos meus irmãos pelo companheirismo e amizade.

Ao meu namorado Thiago, sempre paciente e presente em todos os momentos.

A todos meus familiares que me ajudaram, de alguma forma, a alcançar meus objetivos.

Ao Prof. Dr. Emanuel Carrilho, pela orientação, pelas oportunidades concedidas desde minha iniciação científica, pela paciência e disponibilidade.

À Profa. Dra. Francesca Sciandra e ao Prof. Dr. Andrea Brancaccio, por terem me ajudado de muito bom grado no projeto, me acolhido em seu laboratório e pela convivência durante meu período de estadia em Roma. 
Ao Prof. Dr. Milos Novotny, que me concedeu a oportunidade de aprender mais sobre os estudos de açúcares, por ter aberto as portas de seu laboratório para men estágio PDEE e pelo suporte concedido durante este período.

Ao Prof. Dr. Huaiyu Hu que, sem nem me conhecer ou ter ouvido falar de mim antes, ajudou muito quando tive problemas durante o desenvolver do meu projeto.

À Profa. Dra. Patsy Nishina e à Prof. Dra Mariz Vainzof, que também contribuiram para a realização dos experimentos, através da doação dos modelos animais.

Ao Prof. Dr. Nilson Assunção, por me auxiliar nos experimentos de espectrometria de massas.

A todos meus colegas e companheiros de trabalho do laboratório BioMicS, da Universidade de Indiana e da Università Cattolica del Sacro Cuore, com os quais aprendi bastante e tive ótimas experiências de vida. 
A todos os docentes e funcionários da USP que garantiram o término de minha jornada como pós-graduanda no IQSC e sempre estiveram dispostos a me ajudar no que fosse necessário.

A todos os amigos que estiveram ao meu lado dando apoio, me escutando e dando conselhos valiosos.

Ao CNPq (processos 140840/2008-7 e 160528/2011-9), pela bolsa concedida.

À CAPES (processo 0203-10-6), pela bolsa de estágio PDEE concedida.

À FAPESP (processo 2009/16598-7), pelo auxílio financeiro concedido para o desenvolvimento desta pesquisa. 


\section{Epígrafe}

"Pois tudo que é grandioso é perigoso; e é verdade, como diz o adágio, que o que é belo é difícil." Sócrates (A República) 


\section{Resumo}

A glicosilação é uma das modificações mais comuns ocorridas naturalmente nas cadeias polipeptídicas. As glicoproteínas exercem papéis essenciais para os seres vivos desde o ínicio vida e, por essa razão, qualquer mutação nos resíduos de açúcares a elas ligados causam diversos efeitos não desejados ao indivíduo. O padrão de glicosilação de proteínas é regido tanto por fatores genéticos quanto por fatores externos. Em relação aos defeitos de glicosilação hereditários, diversas mutações em genes específicos causam anormalidades na síntese de glicoproteínas. No grupo de doenças causadas por defeitos de glicosilação hereditários estão incluídas algumas distrofias musculares relacionadas a mutações em proteínas que são glicosiltransferases comprovadas ou putativas. O uso de modelos animais facilita o estudo dessas doenças neuromusculares e, por isso, o presente trabalho foi desenvolvido utilizando tecidos de camundongos controle (C57Black6) e LARGE. O camundongo LARGE possui características fenotípicas semelhantes às de humanos afetados pela distrofia muscular congênita tipo 1D. Diferentes estratégias de análise e de instrumentação foram empregadas para a obtenção de informações relacionadas tanto ao conjunto de glicoproteínas em geral quanto à alfa-distroglicana especificamente. A alfadistroglicana mostra-se modificada em relação aos resíduos de açúcares nela ligados em animais com mutação no gene LARGE, resultando em diversos problemas de saúde. A técnica de eletroforese bidimensional, aliada à pré-purificação das glicoproteínas por colunas de lectinas e posterior identificação por espectrometria de massas, não garantiu a obtenção de resultados adequados para esta classe de estruturas. Portanto, a comparação glicoproteômica de tecidos musculares de animais controle e LARGE não foi bem sucedida por esta estratégia instrumental. Técnicas imunoanalíticas, em destaque o western blot, por sua vez, garantiram a visualização das diferenças de glicosilação da alfa-distroglicana, e experimentos de cromatografia de imunoafinidade iniciados neste trabalho mostraram o potencial da especificidade de interação anticorpo-antígeno no isolamento desta glicoproteína para estudos futuros de seus resíduos de oligossacarídeos. Finalmente, análises de espectrometria de massas dos resíduos de oligossacarídeos isolados das glicoproteínas foram realizadas. Os resultados obtidos indicaram a necessidade de otimização do preparo e purificação mais eficiente dessas amostras, mas alguns íons puderam ser relacionados a N-e O-glicanas. 


\section{Abstract}

Glycosylation is one of the most common modifications that occur naturally in the polypeptide chains. Glycoproteins play key roles in living organisms from the beginning of life and, therefore, any mutation in the sugar residues attached to them may cause many undesirable effects. The glycosylation pattern of proteins is regulated by both genetic and external factors. Regarding hereditary defects of glycosylation, different mutations in specific genes cause abnormalities in the synthesis of glycoproteins. In the group of diseases caused by defective glycosylation are included some hereditary muscular dystrophies, related to mutations in proteins that are proven or putative glycosyltransferase. The use of animal models facilitates the study of neuromuscular diseases and, therefore, this study was conducted using tissues from control mice (C57Black6) and LARGE. The LARGE mouse has phenotypic characteristics similar to those of humans affected by congenital muscular dystrophy type 1D. Different strategies for analysis and instrumentation were employed here to obtain information related both to the set of glycoproteins in general and specifically to alpha-dystroglycan. The alpha-dystroglycan is modified in relation to its linked sugar residues in animals with LARGE gene mutation, resulting in several health problems. Twodimensional electrophoresis technique, coupled with the pre-purification of glycoproteins by lectin column and subsequent identification by mass spectrometry, did not guarantee resultssuited for this class of structures. Therefore, the glycoproteomic comparison of muscle tissues from LARGE and control animals was not effective by this instrumental strategy. Immunoanalytical techniques, highlighting here the western blot, in turn, assured the visualization of the differences in glycosylation of alpha-dystroglycan, and immunoaffinity chromatography experiments undertaken in this work indicate the potential of the specific antibody-antigen interaction in isolation of this glycoprotein for the future study of their attached oligosaccharides. Finally, mass spectrometer analyses of the isolated oligosaccharides residues of the glycoproteins were performed. The results indicated the need for optimization of preparation and purification of these samples more efficiently, but some ions could be related to $\mathrm{N}$-and $\mathrm{O}$-glycans. 


\section{Lista de Ilustrações}

\section{Capítulo 1}

\section{Glicoproteínas e doenças relacionadas}

Figura 1.1 - Sítios de ligação de glicanas N- e O-ligadas.

Figura 1.2 - Diagrama da organização molecular de componentes integrais e periféricos do DGC e outras proteínas envolvidas em distrofias musculares do músculo esquelético.

\section{Capítulo 2}

\section{Análise Proteômica e Glicoproteômica de Modelos Animais}

Figura 2.1 - Esquema ilustrativo das etapas de separação por 2-DE.

Figura 2.2 - Modos de inserção de amostra nas fitas de IEF.

Figura 2.3 - Músculos de camundongo coletados para os experimentos de proteômica.

Figura 2.4 - Protocolo 1 - parâmetros de IEF empregados para a separação na primeira dimensão.

Figura 2.5 - Géis das amostras dissolvidas nos diferentes tampões de reidratação listados na Tabela 2.2.

Figura 2.6 - Géis das amostras purificadas por precipitação ou diálise seguida por liofilização.

Figura 2.7 - Géis 2-D de proteínas extraídas de músculo gastrocnêmio de camundongo com 8 semanas de idade.

Figura 2.8 - Géis 2-DE de proteínas extraídas de músculo gastrocnêmio de camundongo com 8 semanas de idade.

Figura 2.9 - Proteínas extraídas de músculo gastrocnêmio de camundongo com 8 semanas de idade, separadas por 2-DE.

Figura 2.10 - Diagrama de Venn mostrando a sobreposição de proteínas identificadas nos géis ilustrados na Figura 2.8.

\section{Capítulo 3}

\section{Caracterização da $\alpha$-DG por técnicas imunoanalíticas}

Figura 3.1 - Representação esquemática de uma molécula de anticorpo. 
Figura 3.3 - Experimento de controle interno positivo (WB), com utilização de anti $\beta$-actina, específico para proteína de camundongos.

Figura 3.4 - WB realizado com anti $\beta$-DG específico para proteína de camundongos. 70

Figura 3.5 - Organização do domínio distroglicana. $\quad 70$

Figura 3.6 - WB realizado com anti $\alpha$-DG, VIA4-1. $\quad 72$

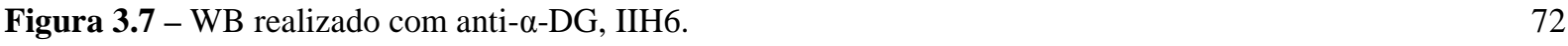

Figura 3.8 - Laminin overlay mostrando ausência de ligação de laminina nas amostras LARGE. 73

Figura 3.9 - WB realizado com o sobrenadante de hibridoma sx/3/50/25 ${ }^{[13]}$ (IgG anti $\alpha$-DG). 74

Figura 3.10 - Cromatografia de imunoafinidade. Anticorpo: sobrenadante de hibridoma sx/3/50/25 77 (IgG anti- $\alpha-D G)$.

\section{Capítulo 4}

\section{Glicômica de Tecidos Musculares de Modelos Animais}

Figura 4.1 - Modos de digestão de oligossacarídeos ligados a proteínas.

Figura 4.2 - Espectro de massas por MALDI-TOF no modo positivo reflectron. N-glicanas extraídas de glicoproteínas presentes em gastrocnêmio de camundongo controle.

Figura 4.3 - Espectro de massas por MALDI-TOF no modo positivo reflectron. O-glicanas extraídas de glicoproteínas presentes em gastrocnêmio de camundongo controle. 


\section{Lista de Tabelas}

\section{Capítulo 1}

\section{Glicoproteínas e doenças relacionadas}

Tabela 1.1 - Modelos de camundongos para distrofias musculares.

\section{Capítulo 2}

\section{Análise Proteômica e Glicoproteômica de Modelos Animais}

Tabela 2.1 - Composição do tampão de extração e solubilização de proteínas (pH 7,4).

Tabela 2.2 - Composição dos tampões testados para ressolubilização das proteínas e reidratação das fitas de IEF.

Tabela 2.3 - Composição da solução de equilíbrio das fitas de IEF.

Tabela 2.4 - Resultados obtidos com os tampões de reidratação testados.

\section{Capítulo 3}

\section{Caracterização da $\alpha$-DG por técnicas imunoanalíticas}

Tabela 3.1 - Composição do tampão de amostra para SDS-PAGE, concentrado 4×. 


\section{Lista de Esquemas}

\section{Capítulo 2}

Análise Proteômica e Glicoproteômica de Modelos Animais

Esquema 2.1 - Reação de degradação da uréia e carbamilação de peptídeos.

Esquema 2.2 - Especificidade da digestão tríptica.

\section{Capítulo 4}

\section{Glicômica de Tecidos Musculares de Modelos Animais}




\section{Lista de abreviações e siglas}

- 2-DE: (two-dimensional electrophoresis) eletroforese bidimensional.

- ACN: acetonitrila.

- $\alpha$-DG: alfa-distroglicana.

- BCA: (bicinchoninic acid) ácido bicinconínico.

- $\beta$-DG: beta-distroglicana.

- BSA: (bovine serum albumin)albumina de soro bovino.

- CDG: (congenital disorders of glycosylation) doenças congênitas de glicosilação.

- CID: (collision-induced dissociation) fragmentação induzida por colisão.

- CMD: (congenital muscular dystrophy) distrofia muscular congênita.

- DGC: (dystrophin-glycoprotein complex) complexo distrofina-glicoproteína.

- DHB: ácido 2,5-dihidroxibenzóico.

- DMF: dimetilformamida.

- DTT: ditiotreitol.

- ECL: enhanced chemiluminescence.

- ESI: (electrospray ionization) ionização por electrospray.

- HRP: horseradish peroxidase.

- IAA: iodoacetamida.

- ICR-FT: (ion cyclotron resonance-fourier transform) ressonância ciclotrônica de íons por transformada de Fourier.

- IEF: (isoelectric focusing) focalização isoelétrica.

- MALDI: (matrix-assisted laser desorption/ionization) dessorção/ionização a laser assistida por matriz.

- MM: massa molecular.

- MS: (mass spectrometry) espectrometria de massas.

- NL: não linear.

- NP40: nonidet P-40.

- pI: ponto isoelétrico.

- $\mathrm{PMF}$ : peptide mass fingerprinting . 
- PMSF: (phenylmethanesulfonyl fluoride) fluoreto de fenilmetilssulfonila.

- PTM: (post-translational modifications) modificações pós-traducionais.

- SDS: (sodium dodecyl sulfate) dodecil sulfato de sódio.

- TCA: (trichloroacetic acid) ácido tricloroacético.

- TFA: (trifluoracetic acid) ácido trifluoroacético.

- TOF: (time of flight) tempo de vôo.

- T-PBS: Tween- phosphate buffered saline.

- WB: Western blotting.

- WGA: wheat germ agglutinin. 


\section{Sumário}

Capítulo 1

Glicoproteínas e doenças relacionadas

1.1 Introdução

1.1.1 Glicoproteínas

1.1.2 Defeitos de glicosilação hereditários

1.1.3 O complexo distrofina-glicoproteína

1.1.4 Modelos animais

1.2 Objetivos gerais

1.3 Bibliografia

Capítulo 2

12

Análise Proteômica e Glicoproteômica de Modelos Animais

2.1 Introdução

2.1.1 Preparo de amostra

2.1.2 Identificação das proteínas do gel 


\subsection{Experimental}

2.3.1 Extração e processamento de amostras musculares de modelos murinos

2.3.2 Otimização da composição do tampão para ressolubilização das proteínas e reidratação das fitas de IEF

2.3.4 Pré-purificação das glicoproteínas por wheat germ agglutinin (WGA)

2.3.6 Coloração dos géis de 2-DE

2.3.7 Digitalização e análise dos géis

2.3.8 Digestão in gel com tripsina

2.3.9 Análise dos peptídeos por LC-MS/MS

\subsection{Resultados e discussão}

2.4.1 Otimização da composição do tampão para ressolubilização das proteínas e reidratação das fitas de IEF

2.4.2 Precipitação das proteínas 
2.6 Bibliografia

Capítulo 3

56

Caracterização da $\alpha$-DG por técnicas imunoanalíticas

3.1 Introdução

3.1.1 Anticorpos

3.1.2 Princípios da técnica de WB

3.2 Objetivos

63

3.3 Experimental

64

3.3.1 Extração, processamento e purificação de amostras musculares de modelos murinos

3.3.2 SDS-PAGE e blotting

3.3.3 Imunodetecção

3.3.4 Laminin overlay

3.3.5 Cromatografia de imunoafinidade

3.4 Resultados e discussão

3.5 Conclusão

78

3.6 Bibliografia 
Capítulo 4

81

Glicômica de Tecidos Musculares de Modelos Animais

4.1 Introdução

4.2 Objetivos

86

4.3 Experimental

4.3.1 Extração, processamento e purificação das glicoproteínas

4.3.2 Digestão das N-glicanas e purificação

4.3.3 Redução e permetilação das N-glicanas

4.3.4 Digestão das O-glicanas

4.4 Resultados e discussão

91

4.5 Conclusão

96

4.6 Bibliografia

97 


\section{Prefácio}

Esta tese foi dividida em quatro capítulos. O Capítulo 1 apresenta uma revisão bibliográfica sobre o problema biológico que inspirou o desenvolvimento de todo o trabalho analítico, e traz os objetivos gerais que englobam toda a tese. Os demais capítulos foram divididos de acordo com a técnica instrumental utilizada para o estudo, e os objetivos específicos buscados com sua utilização. Mais especificamente, o Capítulo 2 trata dos experimentos de eletroforese bidimensional para análise das glicoproteínas totais extraídas de tecidos musculares, o Capítulo 3 é mais focado na $\alpha$-distroglicana, e seu perfil de glicosilação, e o Capítulo 4 aborda o estudo glicômico destas amostras empregadas. 
Capítulo 1

\section{Glicoproteínas e doenças relacionadas}




\subsection{Introdução}

Das inúmeras proteínas decodificadas pelo genoma de seres eucarióticos, uma grande parte delas são modificadas co- e pós-traducionalmente, seja por acetilação, fosforilação, oxidação, metilação, glicosilação, entre outras mais. ${ }^{1-3}$

As modificações pós-traducionais (post-translational modifications - PTM) ocorrem por alterações em um ou mais aminoácidos de uma mesma proteína, através de ligações covalentes. Essas modificações são resultados da ação de enzimas ou de fatores externos, como estresse, idade, doenças etc. ${ }^{1-3}$

Sem as PTM, não seria possível explicar as inúmeras funções biológicas e os diversos mecanismos regulatórios exercidos pelas proteínas, devido ao limitado número de esqueletos polipeptídicos que podem ser formados a partir dos códigos genômicos, se comparado às inúmeras possibilidades de combinações simultâneas de PTM a esses polipeptídeos. As PTM são essenciais para a definição da estrutura terciária e quaternária das proteínas. Assim, são decisivas para a regulação das funções celulares, sinalização, transporte e localização final das proteínas. Por exemplo, as respostas do sistema imune de um ser vivo estão relacionadas a modificações estruturais que ocorrem nas proteínas no decorrer da vida, assim como o avanço de doenças, e a própria morte celular. ${ }^{1-3}$

\subsubsection{Glicoproteínas}

A glicosilação é uma das modificações mais comuns ocorridas naturalmente nas cadeias polipeptídicas. Esse processo pode ser iniciado desde o alongamento do polipeptídeo e sua entrada ao retículo plasmático, como também no complexo de Golgi. ${ }^{4,5}$

As glicoproteínas são classificadas de acordo com o tipo de ligação que ocorre entre os oligossacarídeos e o peptídeo em questão. A sua formação pode se dar por uma $\mathbf{N}$-ligação no grupo amida de resíduos específicos de asparagina a resíduos de $\mathrm{N}$-acetilglucosamina (GlcNAc), ou por uma O-ligação através de grupos hidroxila, principalmente de resíduos de 
serina ou treonina, via resíduos de $\mathrm{N}$-acetilgalactosamina (GalNAc), manose (Man), xilose ou outros monossacarídeos, ${ }^{6}$ como ilustrado na Figura 1.1.

A biossíntese de glicanas N-ligadas ocorre juntamente com o processo de tradução, e suas etapas acontecem no citosol, no retículo endoplasmático e nos compartimentos de Golgi. As oligossacariltransferases envolvidas nesta biossíntese reconhecem sítios consenso de glicosilação na proteína: Asn-X-Ser/Thr (X pode ser qualquer aminoácido exceto prolina). Em contraste, as glicanas O-ligadas são biossintetizadas pós-tradução, e as etapas se dão principalmente dentro do complexo de Golgi. No caso da biossíntese de glicoproteínas Oligadas, não existem seqüências consenso para O-glicosilações. ${ }^{6}$

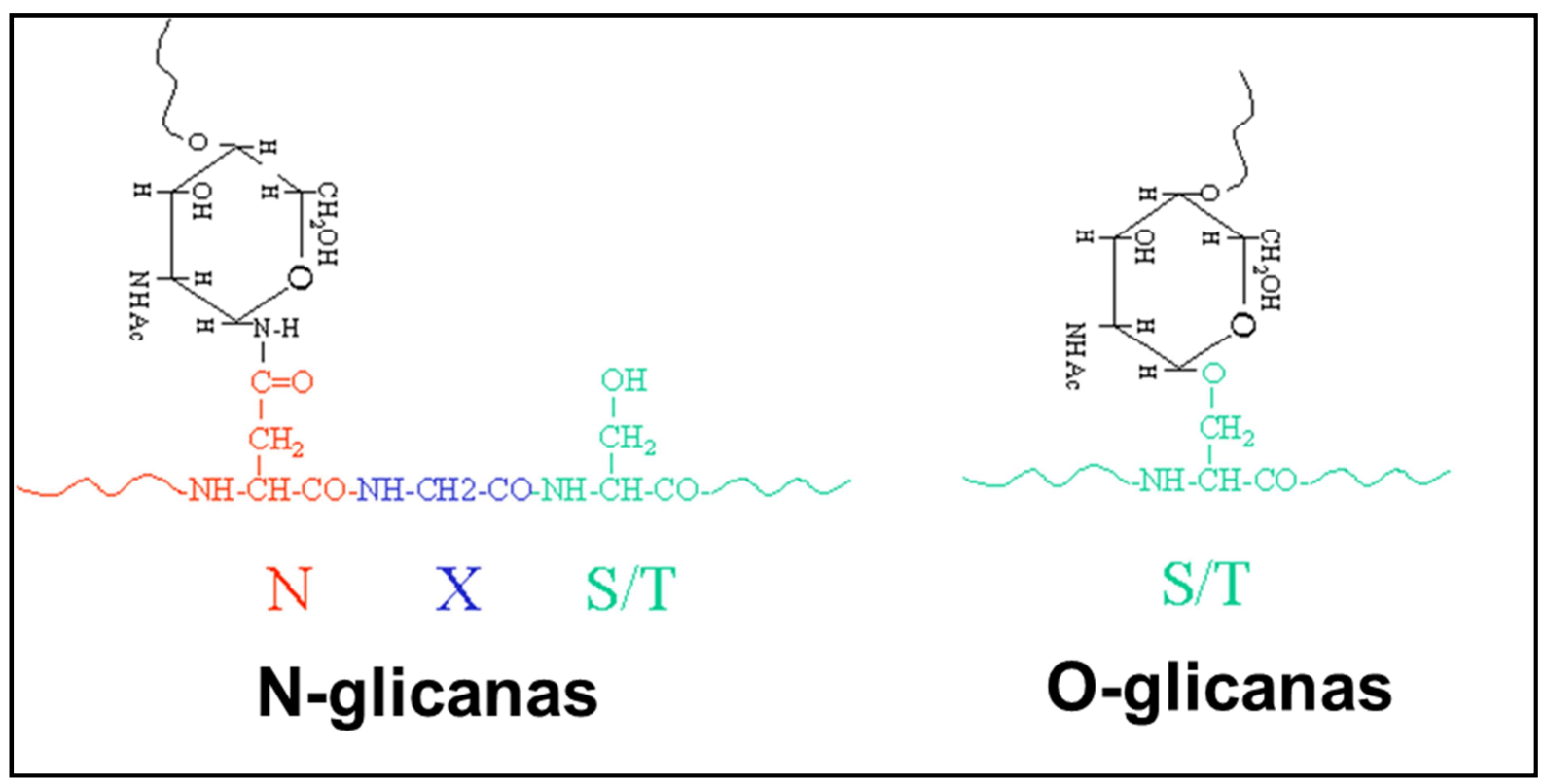

Figura 1.1 - Sítios de ligação de glicanas N- e O-ligadas. ${ }^{7}$

Assim como as demais PTM conhecidas, o padrão de glicosilação de proteínas num determinado indivíduo é regido tanto por fatores genéticos e pré-deteminados, quanto por fatores externos. Cadeias de N- e O-glicanas, assim como o nível de expressão de certas glicoproteínas mostraram ser alterados em diversos tipos de câncer. A fibrose cística é caracterizada pela secreção anormal de mucinas, uma classe específica de O-glicoproteínas. Doenças inflamatórias como artrite reumatóide, e diversos tipos de infecção, inclusive pelo vírus da imunodeficiência humana (HIV) são também influenciadas por glicoproteínas. ${ }^{8}$ Estes são apenas alguns casos de fatores externos que estão relacionados à glicosilação de proteínas. 
As glicoproteínas não estão relacionadas apenas a doenças, mas exercem também papéis essenciais para os seres vivos desde o ínicio vida. Como exemplo pode ser citado o fato de as $\mathrm{N}$-glicoproteínas de superfície celular desempenharem um papel importante na interação entre células envolvidas na diferenciação e desenvolvimento embriônico. ${ }^{9}$ A regulação de funções hormonais também dependem desta classe de compostos, ${ }^{10}$ assim como a capacidade de reprodução. ${ }^{11}$

\subsubsection{Defeitos de glicosilação hereditários}

Os defeitos de glicosilação hereditários englobam anormalidades na síntese de glicoproteínas N-ligadas, O-ligadas, ou ambas e, como o próprio nome diz, estão relacionados não a fatores externos, como os exemplos citados anteriormente, mas à herança genética. Os defeitos mais estudados no momento estão organizados em grupos conhecidos como doenças congênitas de glicosilação (congenital disorders of glycosylation - CDG), com as falhas ocorrendo nas etapas de alongamento (CDG tipo 1) ou de processamento (CDG tipo 2) dos oligossacarídeos. ${ }^{6}$

Entre as diversas CDG conhecidas estão incluídas algumas distrofias musculares relacionadas a mutações em proteínas que são glicosiltransferases comprovadas ou putativas. Quatro formas severas de distrofias musculares congênitas (congenital muscular dystrophy CMD) e suas variantes são comprovadamente relacionadas a defeitos de glicosilação: a síndrome de Walker-Warburg (Walker-Warburg syndrome - WWS), a distrofia muscular congênita de Fukuyama (FCMD), a doença do músculo-olho-cérebro (muscle-eye-brain disease - MEB), as CMD tipo 1C e 1D, além da distrofia muscular do tipo cinturas e suas variantes (limb-girdle muscular distrophy - LGMD). ${ }^{12}$

As patogenias envolvidas na WWS, na FCMD, na MEB e nas CMD tipo 1C e 1D são todas consequências de defeitos de glicosilação numa proteína em especial, a alfadistroglicana ( $\alpha-\mathrm{DG})$. Estes defeitos de glicosilação ocorrem por mutação em genes envolvidos na O-manosilação desta proteína. Um exemplo de glicana O-manosilada

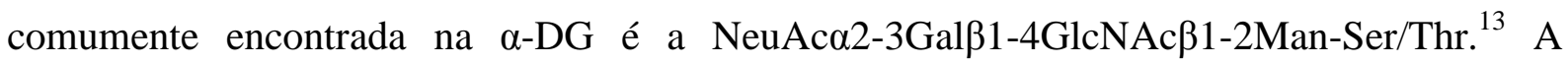
primeira etapa da síntese desta glicana envolve uma ou mais proteínas da família das O- 
manosiltransferases (protein O-manosyltransferases - PMTs), que são altamente conservadas. Os açúcares ligados à $\alpha$-DG possuem um papel fundamental para a ligação apropriada de componentes da matriz extracelular, como laminina, neurexina e agrina à $\alpha$-DG. ${ }^{14}$

As principais alterações patológicas da WWS incluem malformações cerebrais como hidrocefalia, lisencefalia, fusão dos hemisférios entre outras, além de anormalidades oculares que incluem catarata e microftalmia, e distrofia muscular congênita. Esta síndrome pode ocorrer devido a mutações tanto nos genes POMT1 ou POMT2, quanto nos genes FCMD ou FKRP. ${ }^{13}$ Os aspectos clínicos da FCMD e MEB são semelhantes aos citados para a WWS. O gene responsável pela FCMD é localizado no cromossomo 9q31, que codifica a proteína fukutina. A fukutina possui uma região N-terminal hidrofóbica, que pode ser uma sequência sinal ou um domínio transmembrânico. ${ }^{15} \mathrm{~A}$ análise de sua sequência peptídica leva à conclusão que a fukutina possa ser uma enzima modificadora de glicoproteínas e glicolipídios da superfície celular. ${ }^{16}$ Por sua vez, MEB é causada por mutações no gene codificador da POMGnT1, que forma ligações GlcNAcß1-2Man nas O-manosil glicanas, e as CMD tipo 1C e 1D são causadas por mutações nos genes FKRP (fukutin related protein) e LARGE (nome dado ao gene, do inglês large), respectivamente. Estes genes codificam glicosiltransferases putativas. Mutações no gene FKRP causam, além da CMD1C, a LGMD2I. ${ }^{14,17-21}$

\subsubsection{O complexo distrofina-glicoproteína}

Diversas análises bioquímicas e histológicas realizadas na última década contribuíram para um melhor conhecimento da distribuição e localização de proteínas de interesse na fibra muscular, e para a caracterização do complexo distrofina-glicoproteína (dystrophinglycoprotein complex - DGC) (Figura 1.2). ${ }^{22,23}$

O DGC é um complexo oligomérico de proteínas cuja função exata não está completamente determinada. Existem, no entanto, fortes evidências de que este complexo confere estabilidade estrutural ao sarcolema durante a contração muscular, provendo uma forte ligação mecânica entre o citoesqueleto celular e a matriz extracelular. ${ }^{22-24}$ As proteínas que constituem o DGC podem ser organizadas em três subcomplexos: as proteínas do 
citoesqueleto, distrofinas e sintrofinas; as distroglicanas, localizadas no sarcolema, e as sarcoglicanas e a sarcospan. ${ }^{23}$

A $\alpha$-DG é uma proteína altamente glicosilada, e possui extrema importância para o bom funcionamento do DGC, pois é ela que faz a conexão entre o meio interno e externo das células musculares. Sua massa molecular predita é de aproximadamente $74 \mathrm{kDa}$, porém em cada tecido muscular diferente do corpo humano e de outros animais, ela sofre diferenciações específicas através de diversas glicosiltransferases, e sua massa molecular aparente se torna, portanto, diferente em cada tecido. ${ }^{5}$

O estudo dos defeitos de glicosilações desta proteína nas diversas distrofias pode trazer novas informações sobre sua função exata no sarcolema, além de poder dar respostas a respeito dos aspectos clínicos das distrofias e possíveis tratamentos para os pacientes. ${ }^{4}$

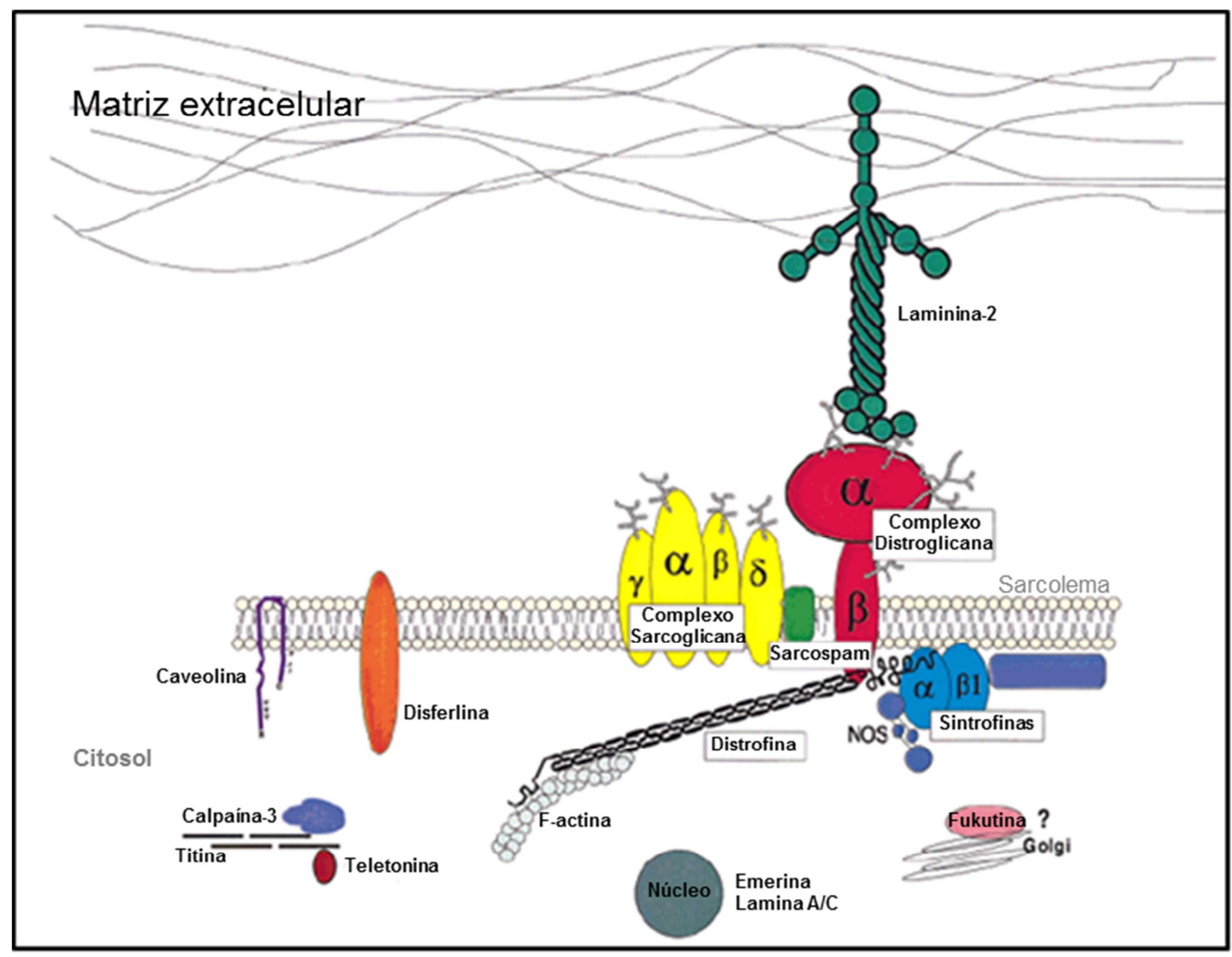

Figura 1.2 - Diagrama da organização molecular de componentes integrais e periféricos do DGC e outras proteínas envolvidas em distrofias musculares do músculo esquelético. ${ }^{23}$ 


\subsubsection{Modelos animais}

Vários modelos animais, que manifestam fenótipos observados nas doenças neuromusculares de humanos, são conhecidos atualmente (Tabela 1.1). Alguns deles foram identificados na natureza, e outros são frutos de manipulação genética. Em geral, estes modelos apresentam alterações fisiopatológicas bastante semelhantes às observadas em humanos e, por isso, podem ser usados como ferramentas para testes genéticos, clínicos e histo-patológicos. O uso de modelos animais para estudos de doenças neuromusculares é facilitada pela disponibilidade de tecido afetado para as análises e, além disso, a individualidade bioquímica destes animais pode ser minimizada através da monitorização adequada das atividades e da alimentação dos mesmos, e do cruzamento específico entre estes indivíduos, o que não pode ser feito com humanos. ${ }^{18,25}$

Tabela 1.1 - Modelos de camundongos para distrofias musculares. ${ }^{26}$

\begin{tabular}{|c|c|c|c|c|}
\hline $\begin{array}{c}\text { Genótipo (proteína } \\
\text { ausente) }\end{array}$ & $\begin{array}{c}\text { Expectativa de } \\
\text { vida }\end{array}$ & $\begin{array}{c}\text { Distrofia } \\
\text { esquelética }\end{array}$ & Cardiomiopatia & $\begin{array}{l}\text { Doença } \\
\text { humana }\end{array}$ \\
\hline Mdx (distrofina) & $>1$ ano & Leve/moderada & Leve & DMD \\
\hline $\begin{array}{c}\text { MyoD/mdx (MyoD, } \\
\text { distrofina) }\end{array}$ & 1 ano & Severa & Severa & - \\
\hline $\begin{array}{l}\text { Utrn-/-/mdx (utrofina, } \\
\text { distrofina) }\end{array}$ & 4-20 semanas & Severa & Severa & - \\
\hline Sgca-/- ( $\alpha$-sarcoglicana $)$ & $>1$ ano & Moderada & Nenhuma & LGMD2D \\
\hline Sgcb-/- ( $\beta$-sarcoglicana) & $>1$ ano & Severa & Severa & LGMD2E \\
\hline Sgcg-/- $(\gamma$-sarcoglicana $)$ & 20 semanas & Severa & Severa & LGMD2C \\
\hline Sgcd-/- ( $\delta$-sarcoglicana $)$ & $>1$ ano & Severa & Severa & LGMD2F \\
\hline DG-/- (distroglicana) & $\begin{array}{c}\text { Embrionicamente } \\
\text { letal }\end{array}$ & - & - & - \\
\hline Myd (LARGE) & Reduzida & Moderada & Nenhuma & CMD1D \\
\hline Dy/dy ( $\alpha 2$-laminina) & 6 meses & Severa & - & CMD1A \\
\hline $\mathrm{Dy}^{2 \mathrm{~J}} / \mathrm{dy}^{2 \mathrm{~J}}(\alpha 2$-laminina $)$ & Reduzida & Moderada/severa & - & CMD1A \\
\hline SJL (disferlina) & $>1$ ano & Leve & - & LGMD2B \\
\hline
\end{tabular}




\subsection{Objetivos gerais}

Os objetivos gerais deste trabalho foram:

- utilizar tecidos musculares de modelos animais para seu estudo glicoproteômico e glicômico. Foram escolhidos os camundongos Myd (LARGE), relacionado à CMD1D (Tabela 1.1), e os animais controle C57Black6;

- emprego das técnicas instrumentais disponíveis para análise destas amostras, visando uma comparação analítica final dos resultados e informações obtidas com cada estratégia empregada;

- contribuir, através do campo da química analítica, para uma futura obtenção de resultados biológicos relevantes para uma melhor compreensão da CMD1D e sua relação com a glicosilação de proteínas. 


\subsection{Bibliografia}

1. SEO, J.; LEE, K-J. Journal of Biochemistry and Molecular Biology, v.37 (1), p.35-44, 2004.

2. PAREKH, R. B.; ROHLFF, C. Current Opinion in Biotechnology, v.8, p.718-723, 1997.

3. CLOOS, P. A. C.; CHRISTGAU, S. Biogerontology, v.5, p.139-158, 2004.

4. MUNTONI, F.; BROCKINGTON, M.; BLAKE, D. J.; TORELLI, S.; BROWN, S. C. The Lancet, v.360, p.1419-1421, 2002.

5. WANG, C.; EUFEMI, M.; TURANO, C.; GIARTOSIO, A. Biochemistry, v.35 (23), p.7299-7307, 1996.

6. SPARKS, S. E. Molecular Genetics and Metabolism, v.87, p. 1-7, 2006.

7. http://www.ionsource.com/Card/carbo/nolink.htm. Acesso em: 4 de Março de 2013.

8. BROCKHAUSEN, I.; SCHUTZBACH, J.; KUHNS, W. Acta Anatomica, v.161, p.3678, 1998.

9. ARMANT, D. R.; KAPLAN, H. A.; LENNARZ, W. J. Developmental Biology, v.113, p.228-237, 1986.

10. SAIRAM, M. R. The FASEB Journal, v.3 (8), p.1915-1926, 1989.

11. MURAMATSU, T. Journal of Biochemistry, v.127, p.171-176, 2000.

12. MUNTONI, F.; TORELLI, S.; BROCKINGTON, M. The Journal of the American Society for Experimental Neurotherapeutics, v.5, p.627-632, 2008. 
13. REEUWIJK, J.; JANSSEN, M.; ELZEN, C.; BERNABÉ, D. B-V.; SABATELLI, P.; MERLINI, L.; BOON, M.; SCHEFFER, H.; BROCKINGTON, M.; MUNTONI, F.; HUYNEN, M. A.; VERRIPS, A.; WALSH, C. A.; BARTH, P. G.; BRUNNER, H. G.; BOKHOVEN, H. Journal of Medical Genetics, v.42, p.907-912, 2005.

14. AKASAKA-MANYA, K.; MANYA, H.; NAKAJIMA, A.; KAWAKITA, M.; ENDO, T. The Journal of Biological Chemistry, v.281, p.19339-19345, 2006.

15. TODA, T.; KOBAYASHI, K.; TAKEDA, S.; SASAKI, J.; KURAHASHI, H.; KANO, H.; TACHIKAWA, M.; WANG, F.; NAGAI, Y.; TANIGUCHI, K.; TANIGUCHI, M.; SUNADA, Y.; TERASHIMA, T.; ENDO, T.; MATSUMURA, K. Basic and Applied Myology, v.13, p.287-292, 2003.

16. ARAVIND, L.; KOONIN, E. V. Current Biology, v.9, p.R836-R837, 1999.

17. TOPALOGLU, H.; BROCKINGTON, M.; YUVA, Y.; TALIM, B.; HALILOGLU, G.; BLAKE, D.; TORELLI, S.; BROWN, S. C.; MUNTONI, F. Neurology, v.60, p.988-992, 2003.

18. LONGMAN, C.; BROCKINGTON, M.; TORELLI, S.; JIMENEZ-MALLEBRERA, C.; KENNEDY, C.; KHALIL, N.; FENG, L.; SARAN, R. K.; VOIT, T.; MERLINI, L.; SEWRY, C. A.; BROWN, S. C.; MUNTONI, F. Human Molecular Genetics, v.12, p. 2853-2861, 2003.

19. BROCKINGTON, M.; BLAKE, D. J.; PRANDINI, P.; BROWN, S. C.; TORELLI, S.; BENSON, S. A.; PONTING, C. P.; ESTOUMET, B.; ROMERO, N. B.; MERCURI, E.; VOIT, T.; SEWRY, C. A.; GUICHENEY, P.; MUNTONI, F. The American Journal of Human Genetics, v.69, p.1198-1209, 2001.

20. GREWAL, P. K.; HOLZFEIND, P. J.; BITTNER, R. E.; HEWITT, J. E. Nature Genetics, v.28, p.151-154, 2001.

21. BROCKINGTON, M.; YUVA, Y.; PRANDINI, P.; BROWN, S. C.; TORELLI, S.; BENSON, M. A.; HERRMANN, H.; ANDERSON, L. V. B.; BASHIR, R.; BURGUNDER, J. M.; FALLET, S.; ROMERO, N.; FARDEAU, M.; STRAUB, V.; STOREY, G.; POLLITT, C.; RICHARD, I.; SEWRY, C. A.; BUSHBY, K.; VOIT, T.; BLAKE, D. J.; MUNTONI, F. Human Molecular Genetics, v.10, p. 2851-2859, 2001.

22. VAINZOF, M.; AYUB-GUERRIERI, D.; ONOFRE, P. C. G.; MARTINS, P. C. M.; LOPES, V. F.; ZILBERZTAJN, D.; MAIA, L. S.; SELL, K.; YAMAMOTO, L. U. Journal of Molecular Neuroscience, v.34, p.241-248, 2008. 
23. COHN, R. D.; CAMPBELL, K. P. Muscle \& Nerve, v.23, p.1456-1471, 2000.

24. LAPIDOS, K. A.; KAKKAR, R.; MCNALLY, E. M. Circulation Research, v.94, p.1023-1031, 2004.

25. NOVOTNY, M. V.; SOINI, H. A.; MECHREF, Y. Journal of Chromatography B, v.866, p.26-47, 2008.

26. DURBEEJ, M.; CAMPBELL, K. P. Current Opinion in Genetics \& Development, v.12, p.349-361, 2002. 
Capítulo 2

Análise Proteômica e

Glicoproteômica de

Modelos Animais 


\subsection{Introdução}

A eletroforese bidimensional (2-DE) é uma técnica de separação tradicionalmente utilizada para análises proteômicas, pois permite que diferentes proteomas complexos sejam comparados, baseando em suas migrações de acordo com o ponto isoelétrico (pI) e massa ou tamanho molecular (MM). Pela 2-DE as proteínas são separadas de acordo com dois parâmetros independentes e ortogonais, primeiramente por focalização isoelétrica (isoelectric focusing - IEF) e seguida por SDS-PAGE, ${ }^{1,2}$ conforme esquematizado na Figura 2.1.
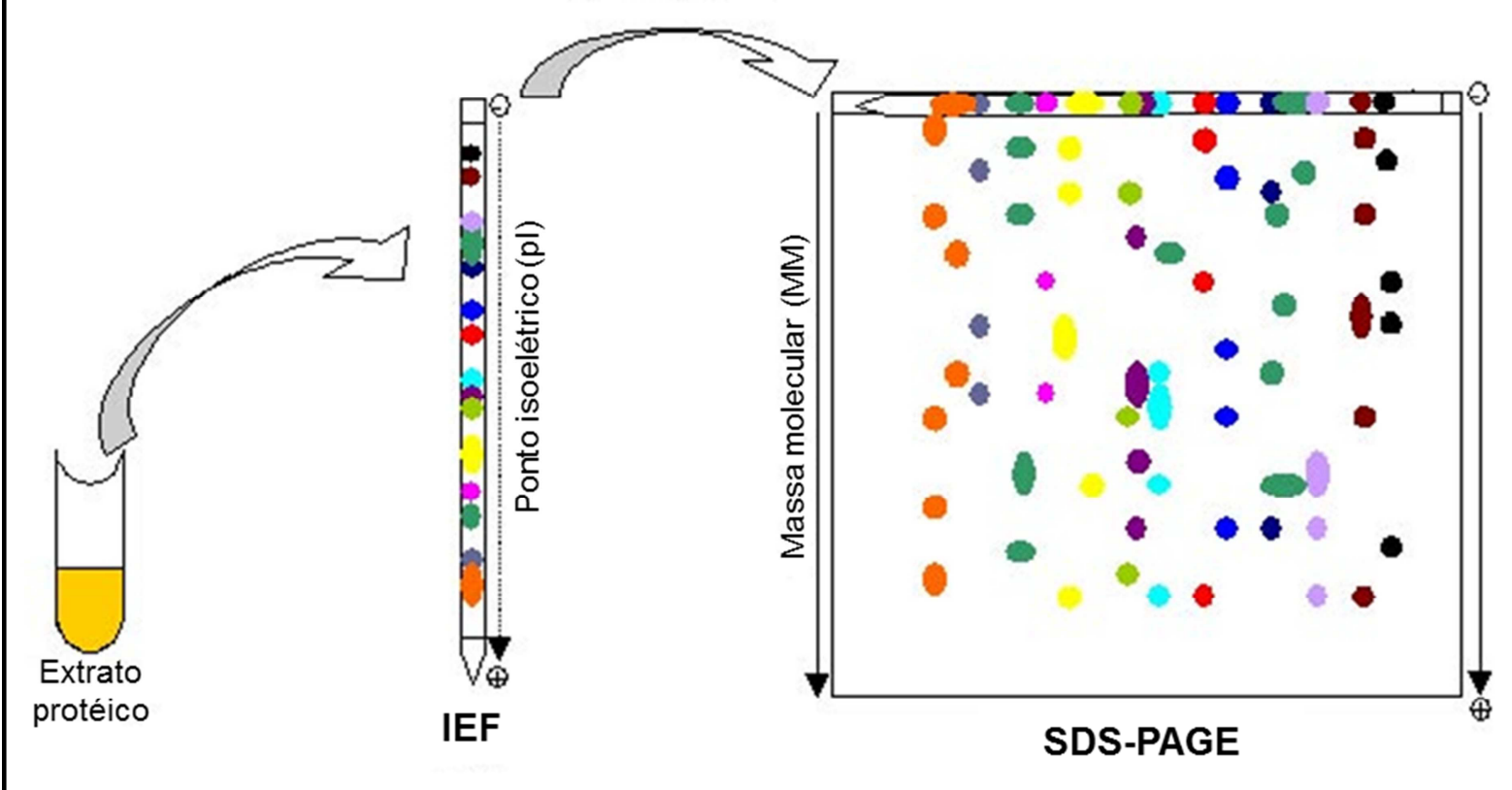

Figura 2.1 - Esquema ilustrativo das etapas de separação por 2-DE. ${ }^{3}$

O número de proteínas que podem ser resolvidas simultaneamente por 2-DE varia de acordo com as dimensões físicas dos géis e com o gradiente de $\mathrm{pH}$ selecionado para a IEF. Mas, em teoria, a 2-DE é capaz de resolver até 10000 proteínas simultaneamente, com a quantificação de proteínas possívelmente em quantidades menores que $1 \mathrm{ng}$ nos géis. ${ }^{2}$ Proteomas mais complexos, como os de mamíferos, podem ser melhor estudados utilizando diversas fitas de IEF com intervalos de $\mathrm{pH}$ mais estreitos, como as de $\mathrm{pH}$ 4,5 - 5,5. Numa faixa de $\mathrm{pH}$ mais estreita, as proteínas com valores de $\mathrm{pI}$ próximos podem ser separadas em diferentes spots, aumentando consideravelmente a resolução da análise. No caso de trabalhos 
envolvendo quantificação, esse ganho de resolução aumenta a confiabilidade dos resultados, diminuindo o número de diferentes proteínas em um único spot do gel (co-migração). Quando diferentes proteínas estão presentes no mesmo spot, pode ocorrer também a supressão do sinal das proteínas minoritárias durante as análises por espectrometria de massas (mass spectrometry - MS), dificultando a identificação das mesmas. ${ }^{4,5}$

Atualmente, um dos procedimentos mais utilizados na primeira dimensão para a introdução de amostra nas fitas de IEF é dissolver as proteínas na própria solução de reidratação, permitindo a adsorção da amostra por toda a extensão da fita (reidratação passiva, Figura 2.2A). Este modo de aplicação é simples e facilita a inserção de uma quantidade maior de proteínas, além de reduzir o tempo de focalização. Outra maior vantagem deste protocolo é que ele minimiza a agregação e precipitação de amostras durante a IEF, o que acontece comumente por cup loading. ${ }^{2}$

Cup loading (Figura 2.2B), por sua vez, também possui alguns diferenciais interessantes que podem ser decisivos em alguns experimentos específicos como, por exemplo, na separação e posterior quantificação de proteínas básicas, ou quando a amostra contém altas concentrações de sais (acima de $100 \mathrm{mmol} \mathrm{L}^{-1}$ ). Vários trabalhos publicados na literatura mostram que a separação de proteínas básicas é muito mais eficiente se inseridas via cup loading, pois proporciona a eliminação de grande parte dos arrastes horizontais visualizados em separações dessa classe de proteínas quando inseridas durante a etapa de reidratação passiva. ${ }^{2,5}$ Além disso, a precisão da quantidade de proteínas totais inserida na fita por cup loading é maior, visto que a amostra é colocada diretamente nos copinhos posicionados sobre as fitas de IEF, eliminando a possibilidade de perda de amostra por adsorção nas paredes das canaletas utilizadas para reidratação das fitas.

Uma modificação do método de aplicação de amostra durante a reidratação se dá através da aplicação de baixas tensões durante esta etapa, geralmente entre 50 e $100 \mathrm{~V}$ (reidratação ativa, Figura 2.2C). Alguns trabalhos publicados relacionam uma maior facilidade de entrada de proteínas de alta massa molecular no interior das fitas de IEF através deste protocolo, e também um ganho de resolução de proteínas ácidas. ${ }^{2}$ Apesar deste método de aplicação de amostra ser bastante promissor, alguns instrumentos comerciais de IEF requerem adaptadores especiais para sua realização, como ocorre no caso do Ettan IPGphor 3 da GE. 


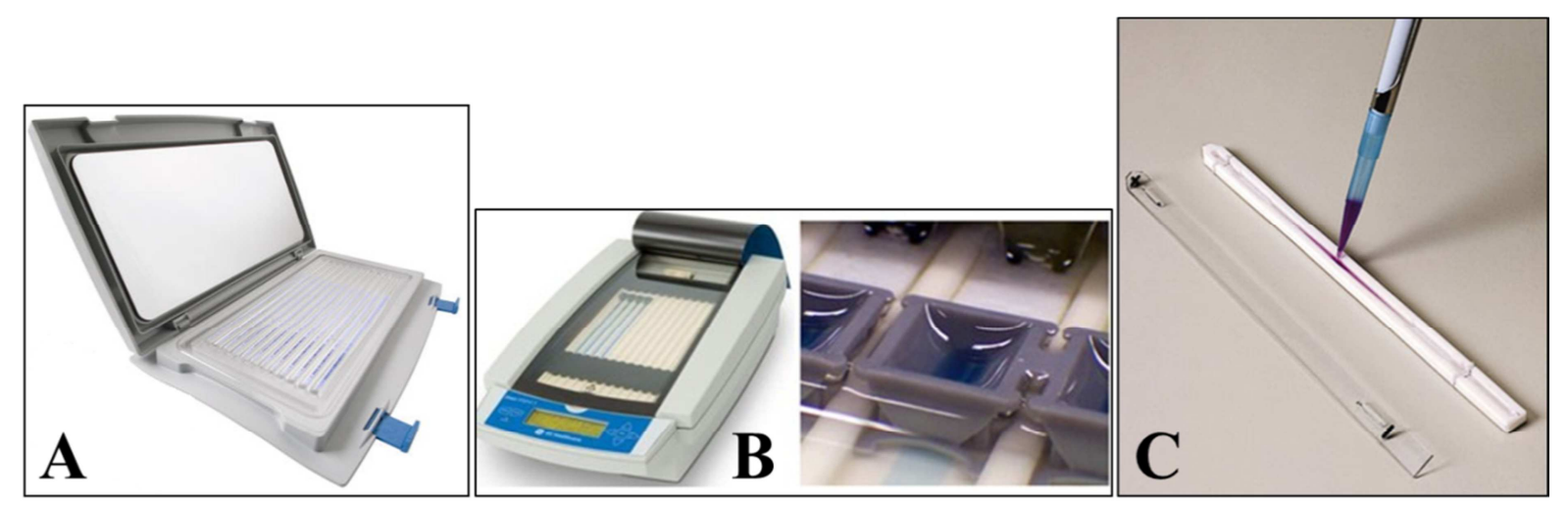

Figura 2.2 - Modos de inserção de amostra nas fitas de IEF: A) reidratação passiva na IPG box; B) cup loading; C) strip holder utilizado para reidratação ativa. ${ }^{6-8}$

Para a separação na segunda dimensão (SDS-PAGE), grandes quantidades de SDS são adicionadas tanto ao gel quanto ao tampão de corrida, a fim de camuflar as cargas intrínsecas das proteínas. Desta forma, os complexos aniônicos SDS-proteína passam a ter uma relação carga negativa por unidade de massa mais ou menos constante, permitindo que a separação nesta etapa seja regida basicamente pela MM da proteína. A concentração de acrilamida usada para o preparo do gel pode ser otimizada para cada amostra, dependendo da massa molecular das proteínas de interesse. Em geral, é possível conseguir bons resultados de separação de proteínas que possuam massa molecular entre 15 e $150 \mathrm{kDa}$. Proteínas menores que $15 \mathrm{kDa}$ não são bem resolvidas em géis de Tris-glicina convencionais, porém a substituição deste tampão para Tris-tricina pode auxiliar na obtenção de separações mais eficientes de proteínas abaixo de $15 \mathrm{kDa}$. Já as proteínas maiores que $150 \mathrm{kDa}$ muitas vezes não são visualizadas no gel de 2-DE porque iniciam sofrendo perdas desde a etapa de inserção de amostra nas fitas de IEF, ou por causa da ineficiência da sua transferência da fita para o gel de SDS-PAGE. Para o último caso citado, é possível conseguir melhores resultados de transferência através da aplicação de baixas voltagens durante o início da corrida na segunda dimensão., ${ }^{2,5}$

\subsubsection{Preparo de amostra}

$\mathrm{Na}$ técnica de 2-DE, as proteínas precisam estar desnaturadas para que sejam separadas em um único ponto do gel. Para isso, cada proteína deve ter uma única conformação na amostra, o que não ocorre em condições nativas. Entretanto, não há um 
procedimento universal para preparo de todas as amostras de 2-DE, pois a origem de cada uma pode variar, podendo ser extraídas de células, tecidos ou mesmo plasma. Assim, cada procedimento deve ser determinado empiricamente, buscando conseguir uma completa solubilização, desagregação, desnaturação e redução das proteínas presentes. ${ }^{2}$

Apesar de não existir uma metodologia padrão para o preparo de amostras para 2-DE, um tópico sempre deve ser levado em consideração para o desenvolvimento da metodologia: o preparo de amostra deve ser o mais simples possível, objetivando uma maior reprodutibilidade dos resultados finais. ${ }^{4,5}$

É necessário minimizar os fatores que possam modificar a composição da amostra em geral, através do uso de inibidores de proteases, do manuseio das amostras em temperaturas e intervalos de tempo adequados, e evitar o uso de compostos que possam degradar ou produzir artefatos durante a análise. ${ }^{4,5}$

No momento do rompimento das células, diversas proteases são liberadas. A proteólise pode comprometer o padrão de separação de um gel de 2-DE. Por isso, as amostras devem estar protegidas destes agentes proteolíticos desde o primeiro momento do rompimento das células, através do processamento das amostras em meios altamente desnaturantes contendo uréia, ácidos ou detergentes. O uso de uma combinação de inibidores de proteases também é útil para garantir a integridade das proteínas de interesse.,

É importante fixar parâmetros como a temperatura para se evitar desigualdades entre amostras preparadas em períodos distintos. Por exemplo, no caso de tampões compostos de uréia, a temperatura não deve exceder $37^{\circ} \mathrm{C}$. Caso contrário, pode ocorrer a degradação deste reagente a isocianato, conforme mostrado no esquema 2.1. Esta molécula de isocianato, por sua vez, pode carbamilar as proteínas, modificando suas cargas e, consequentemente, seus valores de pI. Temperaturas abaixo de $18{ }^{\circ} \mathrm{C}$ também devem ser evitadas, pois podem causar a cristalização deste reagente. $^{5}$ 


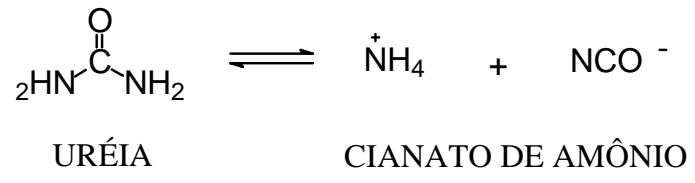

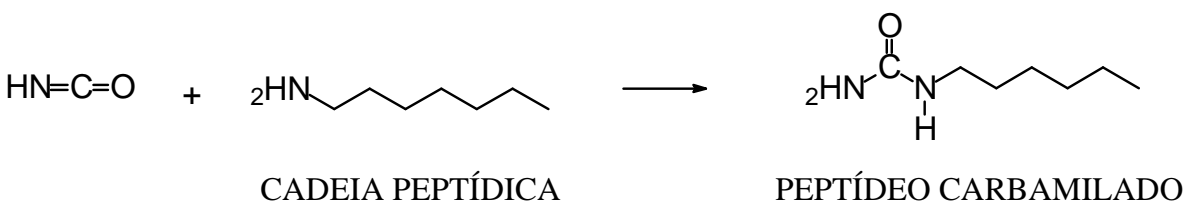

Esquema 2.1 - reação de degradação da uréia e carbamilação de peptídeos.

A diferença de solubilidade das proteínas pode dificultar a análise do proteoma completo de um determinado sistema. Porém, alternativas podem ser usadas para obter informações mais completas sobre as proteínas existentes na amostra. O uso de agentes caotrópicos (uréia, tiouréia), detergentes não iônicos ou zwiteriônicos (CHAPS, Triton X-100 e X-114, nonidet P-40 (NP-40)) e agentes redutores (ditiotreitol - DTT, tributilfosfina - TBP) podem auxiliar a solubilização das proteínas mais hidrofóbicas e de classes diferentes presentes numa mesma amostra.,

Diferentes metodologias de precipitação podem também selecionar uma determinada classe de proteínas a ser separada da amostra total, além de eliminar interferentes como sais, ácidos nucléicos, polissacarídeos, lipídeos e fenóis. Outros procedimentos podem ser igualmente utilizados para pré-fracionamento e pré-purificação das amostras, entre eles centrifugação em gradiente de sucrose, cromatografia (diferentes fases), eletroforese em fase líquida e imunoafinidade. ${ }^{5}$

Quando o objetivo é a análise apenas das glicoproteínas presentes no tecido, uma prépurificação e/ou fracionamento da amostra por cromatografia de lectinas favorece a sua detecção e identificação. Devido à especificidade de ligação das lectinas, os tipos de glicoproteínas presentes numa determinada fração podem ser previstas, conhecendo-se o tipo de lectina utilizada. ${ }^{9-11}$

Como pode ser constatado através da literatura, a otimização de cada etapa de análise por 2-DE é fundamental para a criação de uma metodologia confiável, e também garante a minimização de vários fatores limitantes desta técnica, permitindo a obtenção de resultados mais completos e informativos a respeito da espécie em estudo. 


\subsubsection{Identificação das proteínas do gel}

A identificação das proteínas presentes no gel é obtida principalmente por MS. Após a visualização e fotodocumentação do gel, cada spot é recortado e as proteínas nele presentes são clivadas por diversas enzimas, sendo que a mais utilizada é a tripsina. A tripsina pertence à família das serino-proteases, e rompe as ligações peptídicas C-terminais próximas aos aminoácidos lisina e arginina, exceto quando um resíduo de prolina esteja presente no lado carboxílico do sítio de clivagem, conforme ilustrado no Esquema 2.2 a seguir. $^{12}$ Devido à especificidade do sítio de clivagem da tripsina, é possível determinar a sequência peptídica original e identificar as proteínas presentes em cada spot.

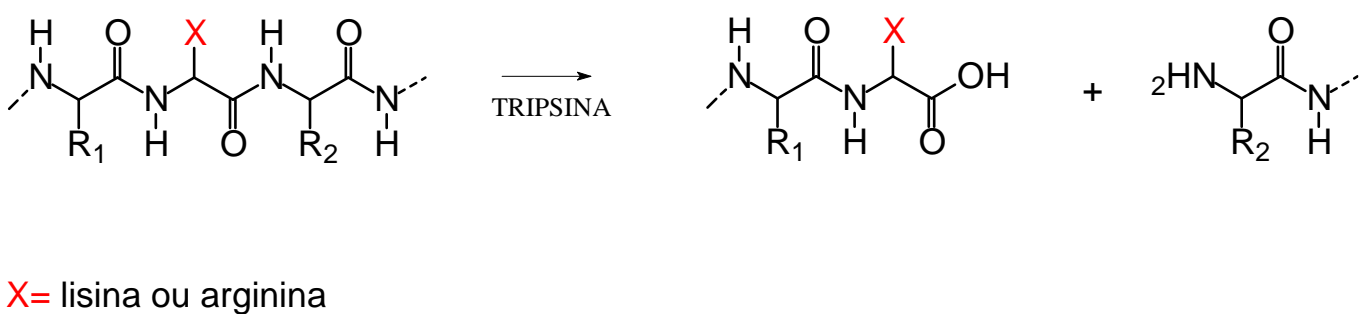

Esquema 2.2 - especificidade da digestão tríptica.

Em razão da alta massa molecular e polaridade dos peptídeos gerados, apenas duas técnicas de ionização são eficientes para ionizá-los e dessolvatá-los: a ionização por electrospray (ESI) e a dessorção/ionização a laser assistida por matriz (MALDI). Por ESI, os íons são formados à pressão atmosférica, enquanto que por MALDI eles são geralmente formados sob vácuo. Estas técnicas de ionização, ditas brandas ou suaves, são capazes de converter moléculas de alta massa molecular à fase gasosa sem afetar sua integridade, tornando possível calcular a massa total de proteínas, seu padrão de clivagem enzimática, conhecido como peptide mass fingerprinting (PMF), e estudar seu padrão de fragmentação induzida por colisão (collision-induced dissociation - CID) ou por transferência de elétrons (electron transfer dissociation - ETD). ${ }^{13}$

Diversos analisadores de massas podem ser associados a essas técnicas de ionização. É nesta parte do instrumento de MS que os íons são discriminados de acordo com seus valores de $m / z$. Os mais utilizados para análise proteômica são quadrupolo (Q), ion trap (IT), tempo de vôo (time of flight - TOF), orbitrap, e ressonância ciclotrônica de íons por transformada de 
Fourier (ICR-FT), podendo ser utilizados isoladamente ou em conjunto, gerando assim analisadores híbridos ou tandem. ${ }^{14,15}$ Cada um destes analisadores possuem diferenciais relacionados a custo, resolução e também faixa de massa analisável. Portanto, sua escolha depende tanto dos objetivos do experimento quanto da viabilidade de custo. ${ }^{16}$

A estratégia mais utilizada para análises proteômicas é combinar os dados obtidos por MS e o uso de programas específicos para busca em bancos de dados. O emprego desses tipos de programas permite a identificação de proteínas presentes em amostras complexas sem que seja necessário a análise concomitante de padrões de proteínas isoladas. Basicamente, o que estes programas fazem é comparar espectros experimentais com espectros teóricos criados pelo banco de dados. Existem diferentes programas disponíveis atualmente, e podem ser classificados de acordo com os algoritmos de score empregados, sendo os mais conhecidos no campo de proteômica o MASCOT e o SEQUEST. ${ }^{17}$ 


\subsection{Objetivos}

Os principais objetivos deste capítulo foram:

- usar tecidos musculares estriados de camundongos para o desenvolvimento de uma metodologia de análise adequada de suas proteínas por 2-DE.

- compreender melhor a influência de cada etapa do procedimento de análise no resultado final encontrado.

- estudar a viabilidade do uso desta técnica instrumental para a detecção de glicoproteínas específicas relacionadas a distrofias musculares, em especial a $\alpha$-DG. 


\subsection{Experimental}

\subsubsection{Extração e processamento de amostras musculares de modelos murinos}

Os tecidos musculares utilizados nos experimentos foram extraídos de linhagens de camundongos C57Black6 (controle - Ctrl) e LARGE. ${ }^{18}$ (Parecer do comitê de ética encontrase em anexo.) Os animais foram eutanasiados com 8 a 12 semanas de idade, em câmara de $\mathrm{CO}_{2}$. Imediatamente após a eutanásia foram coletados os músculos quadríceps femoral (Figura 2.3 a), tríceps sural (gastrocnêmio e sóleo) (Figura 2.3 b) e diafragma (Figura 2.3 c). Os tecidos foram congelados e armazenados em nitrogênio líquido até o período de realização dos experimentos.
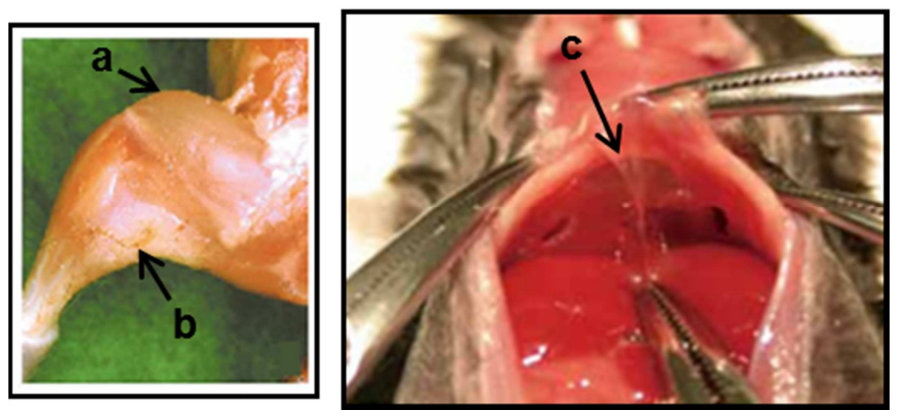

Figura 2.3 - Músculos de camundongo coletados para os experimentos de proteômica: a - quadríceps femoral, b - triceps sural, $\mathbf{c}$ - diafragma. ${ }^{19,20}$

Os músculos selecionados para as análises foram pulverizados com um almofariz e pistilo resfriados em nitrogênio, ou homogeneizados com o uso de um ruptor de tecidos (Qiagen). Pelo último método, as amostras foram homogeneizadas já em tampão apropriado para a extração e solubilização das proteínas. Para os músculos pulverizados no almofariz, o tampão de extração e solubilização foi adicionado após a pulverização. A Tabela 2.1 lista os componentes presentes neste tampão e suas concentrações. Os inibidores de protease utilizados foram fluoreto de fenilmetilssulfonila (PMSF), leupeptina, benzamidina, aprotinina e pepstatina A. 
As proteínas foram extraídas a $4{ }^{\circ} \mathrm{C}$ sob leve agitação, por um período de $10-12 \mathrm{~h}$ (overnight). Após este período, os tubos contendo as amostras foram centrifugados a 10000 rpm por 15 min a $4{ }^{\circ} \mathrm{C}$, para a separação entre precipitado (descartado) e sobrenadante (contendo as proteínas).

Tabela 2.1- Composição do tampão de extração e solubilização de proteínas (pH 7,4).

\begin{tabular}{lc}
\hline \multicolumn{1}{c}{ Reagente } & Concentração final \\
\hline Tris- $\mathrm{HCl}$ & $50,0 \mathrm{mmol} \mathrm{L}^{-1}$ \\
$\mathrm{NaCl}$ & $0,2 \mathrm{~mol} \mathrm{~L}^{-1}$ \\
Triton X-100 & $1 \%(\mathrm{v} / \mathrm{v})$ \\
PMSF & $1,0 \mathrm{mmol} \mathrm{L}^{-1}$ \\
Leupeptina & $1,0 \mu \mathrm{gmL}^{-1}$ \\
Benzamidina & $1,0 \mu \mathrm{g} \mathrm{mL}^{-1}$ \\
Aprotinina & $1,0 \mu \mathrm{g} \mathrm{mL}^{-1}$ \\
Pepstatina A & $1,0 \mu \mathrm{g} \mathrm{mL}^{-1}$ \\
\hline
\end{tabular}

\subsubsection{Otimização da composição do tampão para ressolubilização das proteínas e reidratação das fitas de IEF}

O primeiro parâmetro escolhido para otimização dos experimentos de 2-DE foi o da composição do tampão para ressolubilização das proteínas e reidratação das fitas de IEF. A Tabela 2.2 apresenta os componentes e as respectivas concentrações de cada tampão testado.

Para esta otimização, as demais condições analíticas foram fixadas conforme mencionado a seguir.

Em todos os sobrenadantes contendo as proteínas extraídas foi adicionado $1 \mathrm{~mL}$ de acetona gelada seguido por incubação de 10-12 h. A precipitação ocorreu a $-20{ }^{\circ} \mathrm{C}$, e a mistura foi em seguida centrifugada a $15000 \mathrm{rpm}$ por $10 \mathrm{~min}$, a $4{ }^{\circ} \mathrm{C}$. As proteínas precipitadas foram sempre ressolubilizadas em $125 \mu \mathrm{L}$ de tampão de reidratação e inseridas nas fitas de IEF durante o processo de reidratação, que ocorreu sem aplicação de potencial, por 14-16 h. As fitas utilizadas foram de 7 cm, com intervalo de pH 3-10 não linear (NL). 
Tabela 2.2 - Composição dos tampões testados para ressolubilização das proteínas e reidratação das fitas de IEF.

\begin{tabular}{|c|c|c|c|c|}
\hline & Solução de reidratação & 1 & 2 & 3 \\
\hline \multirow{13}{*}{ 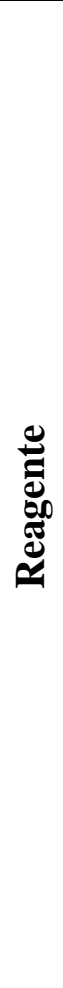 } & Uréia & $7 \mathrm{~mol} \mathrm{~L}^{-1}$ & $7 \mathrm{~mol} \mathrm{~L}^{-1}$ & $7 \mathrm{~mol} \mathrm{~L}^{-1}$ \\
\hline & Tiouréia & $2 \mathrm{~mol} \mathrm{~L}^{-1}$ & $2 \mathrm{~mol} \mathrm{~L}^{-1}$ & $2 \mathrm{~mol} \mathrm{~L}^{-1}$ \\
\hline & CHAPS & $4,0 \%(\mathrm{~m} / \mathrm{v})$ & $2,0 \%(\mathrm{~m} / \mathrm{v})$ & $2,0 \%(\mathrm{~m} / \mathrm{v})$ \\
\hline & Triton X-100 & & $2,0 \%(\mathrm{v} / \mathrm{v})$ & $2,0 \%(\mathrm{v} / \mathrm{v})$ \\
\hline & Isopropanol & $20,0 \%(\mathrm{v} / \mathrm{v})$ & - & - \\
\hline & Glicerol & $10,0 \%(\mathrm{v} / \mathrm{v})$ & - & - \\
\hline & Azul de bromofenol 1\% & $0,002 \%(\mathrm{v} / \mathrm{v})$ & $0,002 \%(\mathrm{v} / \mathrm{v})$ & $0,002 \%(\mathrm{v} / \mathrm{v})$ \\
\hline & Tris & - & - & $20 \mathrm{mmol} \mathrm{L}^{-1}$ \\
\hline & \multirow[t]{4}{*}{ IPG buffer 3-10 NL } & $0,8 \%(\mathrm{v} / \mathrm{v})$ & $0,2 \%$ (a) / 0,4\% (b) / & $0,8 \%(\mathrm{v} / \mathrm{v})$ \\
\hline & & & $0,8 \%(\mathbf{c}) / 1,2 \%(\mathbf{d}) /$ & \\
\hline & & & $1,6 \%(\mathbf{e}) / 2,0 \%$ (f) & \\
\hline & & & $(\mathrm{v} / \mathrm{v})$ & \\
\hline & DTT & $2,5 \%(\mathrm{~m} / \mathrm{v})$ & $3,0 \%(\mathrm{~m} / \mathrm{v})$ & $3,0 \%(\mathrm{~m} / \mathrm{v})$ \\
\hline
\end{tabular}

As condições de IEF empregadas nesta etapa seguiram os parâmetros sugeridos pelo manual do instrumento (Protocolo 1), e estão descritas na Figura 2.4.

Após a focalização, as fitas foram equilibradas por $15 \mathrm{~min}$ com $2,5 \mathrm{~mL}$ de solução de equilíbrio (Tabela 2.3) contendo $10 \mathrm{mg} \mathrm{mL}^{-1}$ DTT, seguido por mais $15 \mathrm{~min}$ com 2,5 $\mathrm{mL}$ da mesma solução contendo $25 \mathrm{mg} \mathrm{mL}^{-1}$ de iodoacetamida (IAA).

A separação na segunda dimensão foi realizada em géis de poliacrilamida numa concentração de $10 \%$, com a aplicação de $150 \mathrm{~V}$, constante do início ao fim do experimento. A visualização dos spots foi possível através da coloração com coomassie brilliant blue $R$. 


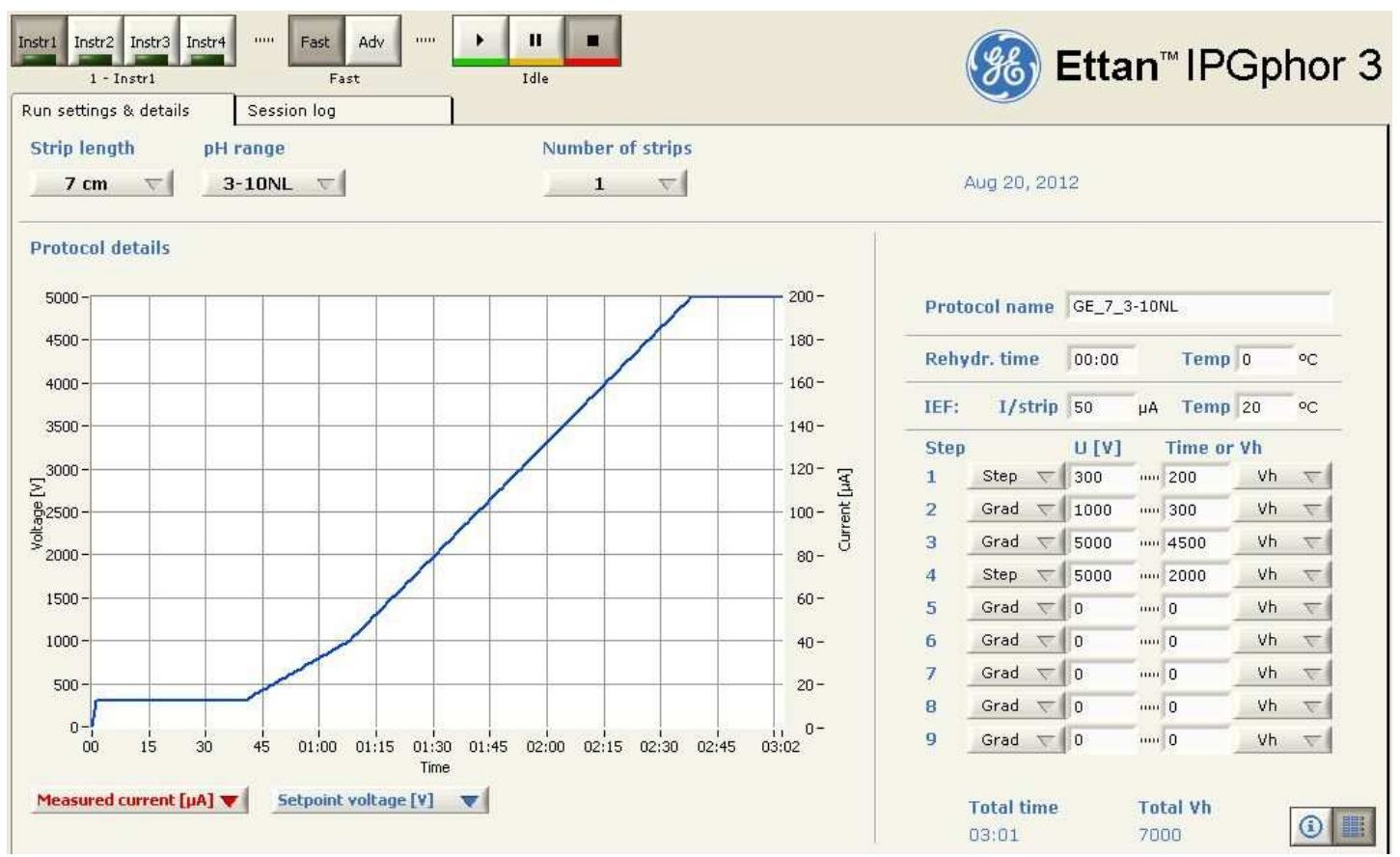

Figura 2.4 - Protocolo 1 - parâmetros de IEF empregados para a separação na primeira dimensão.

Tabela 2.3 - Composição da solução de equilíbrio das fitas de IEF.

\begin{tabular}{lc}
\hline \multicolumn{1}{c}{ Reagente } & Concentração final \\
\hline Tris (pH 8,8) & $75,0 \mathrm{mmol} \mathrm{L}^{-1}$ \\
Uréia & $6,0 \mathrm{~mol} \mathrm{~L}^{-1}$ \\
Glicerol & $29,3 \%(\mathrm{v} / \mathrm{v})$ \\
SDS & $2,0 \%(\mathrm{~m} / \mathrm{v})$ \\
Azul de bromofenol & $0,002 \%(\mathrm{~m} / \mathrm{v})$ \\
\hline
\end{tabular}

\subsubsection{Precipitação das proteínas}

Ao todo, 5 protocolos de precipitação foram testados para as amostras selecionadas:

1. Precipitação com etanol - adição de 9 volumes de etanol gelado $100 \%$ a 1 volume de sobrenadante contendo as proteínas. Incubação a $-20{ }^{\circ} \mathrm{C}$ por $10-12 \mathrm{~h}$. Centrifugação a $15000 \mathrm{rpm}$ por 10 min a $4^{\circ} \mathrm{C}$, para separação do precipitado e do sobrenadante.

2. Precipitação com ácido trifluoracético (TCA) $10 \%$ - adição de um volume adequado de TCA $100 \%$ à amostra, resultando numa concentração final de TCA de 10\%. Incubação a 
$-20{ }^{\circ} \mathrm{C}$ por $30 \mathrm{~min}$. Centrifugação a $15000 \mathrm{rpm}$ por $10 \mathrm{~min}$ a $4{ }^{\circ} \mathrm{C}$, para separação do precipitado e do sobrenadante. Lavagem do precipitado com uma solução de etanol:éter 1:1 (v/v), para eliminação de TCA residual.

3. Precipitação com TCA $10 \%$ em acetona - adição de 10 volumes de TCA $10 \%$ em acetona gelada, a 1 volume de sobrenadante contendo as proteínas. Incubação a $-20{ }^{\circ} \mathrm{C}$ por $10-12$ h. Centrifugação a $15000 \mathrm{rpm}$ por 10 min a $4{ }^{\circ} \mathrm{C}$, para separação do precipitado e do sobrenadante. Descarte do sobrenadante. Adição de 10 volumes de acetona pura e gelada ao precipitado. Agitação em vórtex e incubação por mais 10 min a $-20^{\circ} \mathrm{C}$. Centrifugação a $15000 \mathrm{rpm}$ por $10 \mathrm{~min}$ a $4{ }^{\circ} \mathrm{C}$, para recuperação do precipitado.

4. Precipitação com clorofórmio/metanol - adição de $0,4 \mathrm{~mL}$ de metanol para cada $0,1 \mathrm{~mL}$ de sobrenadante contendo as proteínas. Agitação em vórtex seguida por centrifugação a $15000 \mathrm{rpm}$ por $1 \mathrm{~min}$, a $4{ }^{\circ} \mathrm{C}$. Adição de $0,1 \mathrm{~mL}$ de clorofórmio à mistura. Agitação em vórtex seguida por centrifugação a $15000 \mathrm{rpm}$ por $1 \mathrm{~min}$, a $4{ }^{\circ} \mathrm{C}$. Adição de $0,3 \mathrm{~mL}$ de água, para separação das fases. Remoção e descarte da fase superior. Adição de mais 0,3 $\mathrm{mL}$ de metanol à fase inferior, de clorofórmio. Agitação em vórtex seguida por centrifugação a $15000 \mathrm{rpm}$ por $10 \mathrm{~min}$, a $4{ }^{\circ} \mathrm{C}$. Recuperação do precipitado.

5. Precipitação com acetona - adição de diferentes volumes de acetona pura e gelada a 1 volume de sobrenadante contendo as proteínas. Incubação a $-20{ }^{\circ} \mathrm{C}$ por $10-12 \mathrm{~h}$. Centrifugação a $15000 \mathrm{rpm}$ por $10 \mathrm{~min}$ a $4{ }^{\circ} \mathrm{C}$, para separação do precipitado e do sobrenadante.

\subsubsection{Pré-purificação das glicoproteínas por wheat germ agglutinin (WGA)}

Antes desta etapa de pré-purificação, alíquotas do sobrenadante contendo as proteínas totais foram primeiramente quantificadas. A seguir, uma determinada quantidade de proteínas foi adicionada a volumes específicos de WGA ligadas a agarose, seguindo as especificações de capacidade de ligação da lectina em questão. A fase sólida foi sempre lavada antes da adição das proteínas totais, com o mesmo tampão utilizado durante a homogeneização das amostras de músculo (Tabela 2.1), somente mudando a concentração de Triton X-100, para $0,1 \%$ (v/v). A mistura proteínas - lectina permaneceu sob agitação suave por $10-12 \mathrm{~h}$ a $4{ }^{\circ} \mathrm{C}$. 
Após este período, as proteínas não ligadas foram lavadas com o tampão utilizado para homogeneização (com Triton X-100 a 0,1\% v/v) e em sequência as glicoproteínas foram eluídas com o mesmo tampão, desta vez contendo 0,5 mol L ${ }^{-1}$ de $\mathrm{N}$-acetil-D-glucosamina. Após a purificação, as glicoproteínas foram dialisadas em membrana de acetato de celulose (cut off de1 kDa) e liofilizadas.

\subsubsection{Quantificação das proteínas}

A quantificação das proteínas totais ou purificadas em colunas de WGA foi realizada pelos métodos de Bradford (Biorad) ${ }^{21}$ e/ou ácido bicinconínico (BCA) (Pierce). ${ }^{22}$

\subsubsection{Coloração dos géis de 2-DE}

Dois protocolos de coloração foram comparados, um utilizando coomassie blue R-250 e outro por nitrato de prata. As etapas detalhadas estão descritas a seguir:

Coloração por coomassie blue - Imediatamente após o término da separação na segunda dimensão, cada gel foi colocado numa solução fixadora contendo $30 \%$ etanol e $10 \%$ ácido acético (v/v) e mantidos sob agitação por $30 \mathrm{~min}$. Em seguida a solução fixadora foi trocada pela solução de coomassie $0,025 \%(\mathrm{~m} / \mathrm{v})$, e a coloração do gel se deu por 90 min. Decorrido este período, a solução de corante foi retirada do recipiente contendo o gel e o excesso de coomassie foi eliminado através de diversas incubações em solução descorante (20\% etanol e $5 \%$ ácido acético (v/v)). Após o término do procedimento, o gel permaneceu numa solução preservante preparada com $5 \%$ de ácido acético (v/v).

Coloração por nitrato de prata - A coloração dos géis foi realizada seguindo os procedimentos descritos no manual de instruções do kit de coloração de proteínas por prata PlusOne (GE Healthcare). Resumidamente, os géis foram fixados com uma solução contendo $30 \%$ etanol e 10\% ácido acético (v/v) duas vezes, durante 60 min cada vez. Depois, os géis foram sensibilizados durante 120 min em uma solução preparada com 30\% (v/v) etanol, 6,8\% 
(w/v) acetato de sódio e $0,2 \%(\mathrm{w} / \mathrm{v})$ tiossulfato de sódio, seguido por 5 passos de lavagem com água destilada. Os géis foram incubados em $0,25 \%$ (w/v) nitrato de prata durante 60 minutos, seguido por uma breve lavagem com água, e a visualização dos spots foi possível após a adição de uma mistura de 2,5\% (w/v) carbonato de sódio com 0,08\% (v/v) de uma solução de formaldeído $37 \%$ (w/v). Para interromper a reação, os géis foram colocados em contato com uma solução aquosa de 1,46\% (w/v) EDTA (sal dissódico, dihidratado).

\subsubsection{Digitalização e análise dos géis}

Os géis 2-D foram digitalizados com o III ImageScanner (GE), controlado pelo software Labscan 6.0 (GE). A análise dos spots foi realizada através do software ImageMaster Platinum 2D 7(GE).

\subsubsection{Digestão in gel com tripsina}

Todas as proteínas visíveis foram excisadas do gel manualmente em capela de fluxo laminar e transferidas para microtubos individualmente.

O procedimento para a descoloração e digestão de proteínas coradas com prata foi adaptado a partir de trabalhos previamente publicados, ${ }^{22-25}$ com algumas modificações. Resumidamente, cada banda do gel foi lavada com $500 \mu$ l de água ultrapura (3 vezes, 15 min cada) a temperatura ambiente com agitação suave. Em seguida, a prata presente nas manchas foi reduzida com uma solução contendo $50 \mathrm{mmol} \mathrm{L}^{-1}$ de tiossulfato de sódio e $15 \mathrm{mmol} \mathrm{L}^{-1}$ de ferrocianeto de potássio, durante $5 \mathrm{~min}$ sob agitação. Os agentes redutores da prata foram lavados com $500 \mu \mathrm{l}$ de água ultrapura (3 vezes, 5 min cada), à temperatura ambiente. Em seguida, os pedaços de gel foram equilibrados com $500 \mu \mathrm{l}$ de tampão de bicarbonato de amônio aquoso $100 \mathrm{mmol} \mathrm{L}{ }^{-1}$ (20 min), seguido por uma lavagem com $50 \mathrm{mmol} \mathrm{L}^{-1} \mathrm{de}$ bicarbonato de amônio, contendo 50\% (v/v) de acetonitrila (ACN). Os recortes de gel foram desidratados com $\mathrm{ACN}$, secos e finalmente reidratados com $0,02 \mu \mathrm{g} / \mathrm{uL}$ de tripsina dissolvida 
em $50 \mathrm{mmol} \mathrm{L}^{-1}$ de bicarbonato de amônio. Após uma hora, os tubos com os spots e a tripsina foram incubados a $37{ }^{\circ} \mathrm{C}$ durante a noite. Após a incubação, os sobrenadantes foram transferidos para outros tubos e o restante dos peptídeos foram extraídos a partir dos géis com uma solução feita com $60 \%$ (v/v) ACN e 1\% (v/v) ácido trifluoroacético (TFA). As soluções de peptídeos foram finalmente secas em speed vac e os tubos foram armazenados a $-80{ }^{\circ} \mathrm{C}$ para posterior análise de MS.

Para as proteínas coradas com Coomassie, o protocolo para descoloração e digestão foi realizada como se segue. Os spots foram recortados, lavados durante 5 min com água e equilibrados durante 10 min com solução de bicarbonato de amônio $50 \mathrm{mmol} \mathrm{L}^{-1}$ contendo $50 \%$ (v/v) de ACN. A solução de equilíbrio foi removida e este passo foi repetido até a cor azul desaparecer completamente. Em seguida, os pedaços de gel foram encolhidos pela adição de ACN puro em cada frasco. Assim que os spots ficaram brancos e opacos, o ACN foi descartado e os pedaços de gel foram secos ao ar. Os procedimentos para a digestão e extração dos peptídeos foram semelhantes aos utilizados para os géi de prata.

\subsubsection{Análise dos peptídeos por LC-MS/MS}

Os peptídeos digeridos foram ressuspensos em 30 ul de solução 0,1\% (v/v) TFA e 10 ul de cada amostra (cada amostra continha os peptídeos de um único spot, que foi digerido e analisado separadamente) foi inserido numa coluna analítica Shim-pack XR-ODS II (2,2 $\mu \mathrm{m}$ de tamanho de partícula, $75 \mathrm{~mm}$ x 3,0 mm ID) e separados pela aplicação do seguinte gradiente: 2 a $45 \%$ de fase B de 0 a 25 min, 45 a $90 \%$ de fase B de 25 a 30 min e um intervalo isocrático de $5 \mathrm{~min}$ com $90 \%$ de fase $\mathrm{B}$, a uma vazão de 0,2 ml/min. A Fase A consistiu de 0,1\% (v/v) de ácido fórmico e 20\% (v/v) de ACN. Fase B foi preparada com 0,1\% (v/v) de ácido fórmico e $80 \%(\mathrm{v} / \mathrm{v})$ de ACN. As análises foram realizadas num micro LC Shimadzu Co. (Kioto, Japão) acoplado a um espectrômetro de massas híbrido quadrupolo/tempo-de-vôo (Q-TOF) (MicrOTOF-Q III, Bruker, Berman, Alemanha).

O espectrômetro de massas foi otimizado para analisar no modo scan no intervalo de 70-3000 $\mathrm{m} / \mathrm{z}$; modo positivo; trap ultrascan: 100-2800 m/z; tensão do capilar de $4500 \mathrm{~V}$; nebulizador: 8,0 psi; gás secantes: $5,0 \mathrm{~L} / \mathrm{min}$ e temperatura para evaporação do spray: $220^{\circ} \mathrm{C}$. 
Os experimentos de MS/MS foram realizadas com os 5 íons precursores mais intensos, utilizando uma energia de colisão de $10 \mathrm{eV}$. O sistema de LC e o Q-TOF foram controlados pelos módulos de controle HyStar TM e Esquire do software Compass TM (Bruker).

\subsubsection{Análise de Dados}

Os espectros adquiridos foram pós-processados usando o software Compass 1.3 para micrO-TOF/maXis SR1 (Bruker). Os espectros foram deconvoluídos, os compostos foram detectados automaticamente e os arquivos mascot generic format (MGF) foram criados. Os arquivos MGF foram pesquisados contra o banco de dados Swiss-Prot usando a ferramenta de busca Mascot (www.matrixscience.com/). Os seguintes parâmetros foram fixados para a busca: Mus musculus para taxonomia, tripsina como enzima (máximo de uma clivagem perdida). Carbamidometilação de cisteína como modificação fixa e oxidação de metionina como modificação variável foram definidas. Tolerância massa de íons precursores e fragmento não foi mais do que 1,2 e $0,8 \mathrm{Da}$, respectivamente. A carga de peptídeo monoisotópico foi definida como $1+, 2+$ e $3+$. 


\subsection{Resultados e discussão}

\subsubsection{Otimização da composição do tampão para ressolubilização das proteínas e reidratação das fitas de IEF}

A primeira variável estudada para as análises de 2-DE foi a composição do tampão de reidratação das fitas de IEF. O modo escolhido de aplicação das amostras nas fitas foi sem a aplicação de campo elétrico, durante a etapa de reidratação. Por essa razão, a escolha da composição do tampão de reidratação foi realizada levando-se em conta sua capacidade de solubilização do pellet e sua influência na focalização isoelétrica das proteínas.

Na Tabela 2.4 estão organizados os resultados obtidos com cada tampão testado. A separação final das amostras pode ser visualizada pelos géis ilustrados na Figura 2.4. As amostras utilizadas nesta etapa foram músculos gastrocnêmio de camundongos controle.

Tabela 2.4 - Resultados obtidos com os tampões de reidratação testados.

\begin{tabular}{ccc}
\hline Solução de reidratação (SR) & Solubilização do pellet & Focalização isoelétrica \\
\hline 1 & parcial & adequada \\
$2(\mathrm{a})$ & parcial & adequada \\
$2(\mathbf{b})$ & total & adequada \\
$2(\mathbf{c})$ & total & adequada \\
$2(\mathrm{~d})$ & total & inadequada \\
$2(\mathrm{e})$ & total & inadequada \\
$2(\mathrm{f})$ & total & inadequada \\
3 & total & inadequada \\
\hline
\end{tabular}




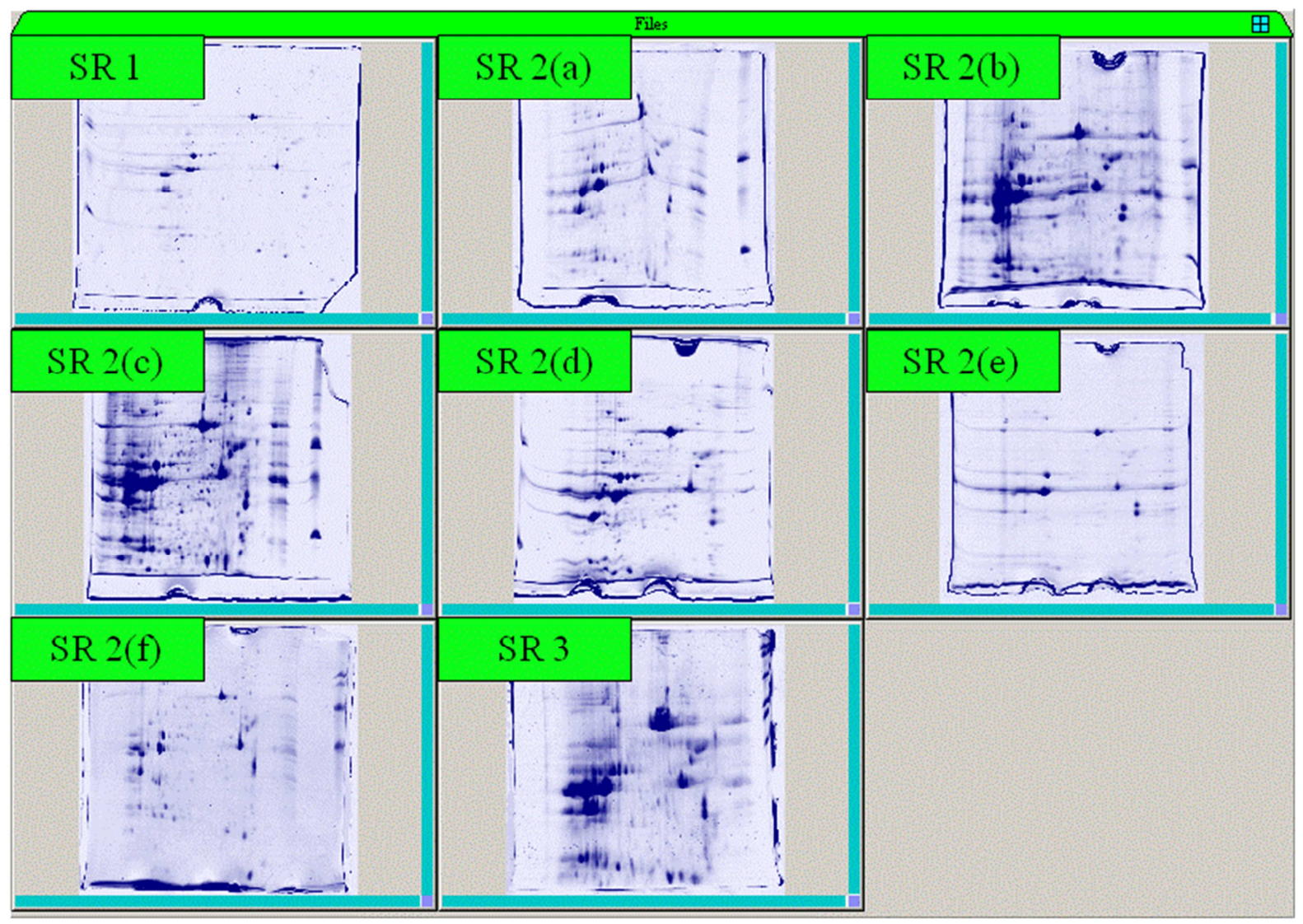

Figura 2.5 - Géis das amostras dissolvidas nos diferentes tampões de reidratação listados na Tabela 2.2. Condições: fitas com intervalo de pH 3-10 não linear (3-10 NL) de $7 \mathrm{~cm}$ de comprimento. Para a segunda dimensão, foram empregados géis de poliacrilamida 10\%. Região básica dos géis sempre à esquerda. Amostras: gastrocnêmio de camundongo controle.

A SR1 foi a primeira solução utilizada nas análises proteômicas de músculo, visto que esta já havia sido utilizada em análises anteriores de 2-DE pelo grupo BioMicS, gerando resultados úteis com outros tipos de amostra. Porém, parte do pellet produzido da amostra de músculo esquelético não foi dissolvido pela SR1, apesar de a IEF ter sido adequada, isto é, apesar de a tensão e a corrente medidas seguirem a linha teórica do protocolo escolhido.

A partir desse resultado inicial com a SR1 e, de acordo com dados publicados em literatura, algumas mudanças foram feitas na composição da solução. A porcentagem de detergente nas demais soluções testadas permaneceu a mesma, porém metade da quantidade de CHAPS foi substituída por Triton X-100. Estes dois detergentes não interferem nas propriedades de carga das proteínas, e por isso não impedem a separação por IEF. Porém, os mesmos possuem características diferentes. Triton X-100 é um detergente não iônico que se mostra especialmente eficiente para a solubilização de proteínas de membranas, mas não é capaz de romper facilmente interações proteína-proteína. Em contrapartida, CHAPS é um 
detergente zwiteriônico adequado para solubilização de proteínas totais, e tem uma capacidade muito maior de desagregar proteínas, se comparado com Triton X-100. ${ }^{26,27}$ Em conjunto, esses detergentes podem solubilizar uma classe mais ampla de proteínas extraídas de músculo.

As concentrações de DTT e IPG buffer também foram modificadas nas demais SR, pois estes reagentes também interferem na capacidade de dissolução das proteínas, assim como a presença ou não de sais na solução, como no caso do Tris.

Conforme descrito na Tabela 2.4, a composição da SR1 e da SR2(a) não garantiu a solubilização de todas as proteínas da amostra e uma separação adequada, resultando em géis com poucos spots (SR1) e/ou com linhas horizontais irregulares (SR2(a)), provavelmente devido à focalização incompleta das proteínas (Figura 2.5). Comparando as SR2 (d), (e) e (f), a única diferença de composição é a porcentagem de IPG buffer adicionado. Apesar de este intervalo de concentração de IPG buffer ter sido adequado para a solubilização de todo o pellet $(1,2-2 \%)$, a IEF foi prejudicada, acarretando o aumento da corrente durante a focalização e do tempo de separação, além da detecção de poucas proteínas resolvidas no gel e presença de linhas horizontais. A faixa de porcentagem de IPG buffer que garantiu tanto a solubilização completa dos pellets quanto uma IEF adequada foi entre 0,4 - 0,8\% (SR2(b) e SR2(c), respectivamente). Porém, analisando mais detalhadamente os géis SR2(b) e SR2(c) da Figura 2.5, é possível visualizar um número maior de spots no gel SR2(c), principalmente na região central. Além disso, a resolução da separação é visivelmente maior no gel SR2(c), e por isso a porcentagem de IPG buffer adotada foi de $0,8 \%$. Por fim, foi testado o efeito que a adição de uma quantidade compatível de Tris traria à análise das amostras. A SR3 possuía uma composição exatamente igual à da SR2(c), apenas com o diferencial de possuir $20 \mathrm{mmol}$ $\mathrm{L}^{-1}$ de Tris. A presença desse sal na amostra gerou aumento da corrente durante a IEF, aumentando o tempo necessário para a focalização, e também prejudicou a resolução de separação, como pode ser verificado pelo gel SR3 ilustrado na Figura 2.5. Com base nos resultados obtidos nesta etapa, a SR escolhida para as demais análises por 2-DE foi a SR2(c), cujos reagentes e suas concentrações estão descritos na Tabela 2.2. 


\subsubsection{Precipitação das proteínas}

O método de purificação de proteínas por precipitação é bastante conhecido e empregado no preparo de amostras para análise por 2-DE, pois a qualidade da separação depende grandemente da eliminação de contaminantes que interferem durante a IEF, destacando-se o excesso de sais. Entretanto, como em outros métodos de concentração e purificação, o uso de precipitantes pode ocasionar efeitos não desejados para o estudo de proteomas totais, como a precipitação não quantitativa, levando à perda de algumas proteínas específicas, e a modificação estrutural de alguns grupos presentes nessas moléculas, como no caso da precipitação por TCA. ${ }^{28}$

A eficiência da precipitação depende de diversos fatores relacionados tanto ao agente precipitante quanto às características físico-químicas das proteínas presentes em solução. A constante dielétrica do meio; o pH; a capacidade de interação do precipitante com a água, causando a redução de moléculas de água livres para hidratar a proteína e deixá-la solúvel, são fatores relacionados ao agente precipitante que irão interferir na qualidade da precipitação. Em relação às proteínas, sua concentração e suas características fisico-químicas irão também influenciar o resultado final. Além disso, o fator temperatura do sistema também deve ser estudado. ${ }^{29,30}$

Por todos esses fatores citados, o estudo e comparação de diferentes métodos de precipitação mostra-se importante para a otimização dos resultados finais de 2-DE, garantindo a geração de informações confiáveis relacionadas ao proteoma de interesse.

Após determinada a composição da SR mais adequada para a solubilização e focalização das proteínas, foram estudados ao todo 5 métodos de precipitação, conforme descrito na seção 2.3.3, para a purificação das proteínas musculares. Os resultados finais foram também comparados com uma amostra preparada através de diálise em membrana de 1 kDa de cut off, seguido por liofilização da solução. Nesta etapa, os protocolos de focalização e da segunda dimensão não foram alterados, sendo semelhantes aos citados na seção 2.3.2.

Na Figura 2.6 estão representados os géis de 2-DE com os diferentes métodos de purificação aplicados: precipitação ou diálise seguida por liofilização. Comparando somente os géis das proteínas precipitadas pelos diferentes métodos, é possível notar que um resultado inadequado foi obtido com a precipitação por TCA $10 \%$ em acetona. As duas linhas 
horizontais mais visíveis no gel podem indicar que provavelmente este método de precipitação não eliminou os principais contaminantes que prejudicam a IEF, por isso houve uma considerável perda de resolução na primeira dimensão. A separação adequada do padrão de massa molecular, visível na extremidade direita do gel, comprova, por sua vez, a polimerização efetiva do gel, sendo este capaz de separar as diferentes proteínas presentes no padrão. Portanto, o resultado de separação obtido com as proteínas musculares provavelmentenão não foi causado pela polimerização incompleta do gel de poliacrilamida, mas sim por problemas na primeira dimensão.

$\mathrm{Na}$ amostra precipitada com etanol, por sua vez, observa-se um pequeno aumento de resolução na separação. Neste gel, é possível notar a presença de dois grupos majoritários de proteínas na parte central e no lado esquerdo (região básica), além de alguns spots mais claros com MM maiores e menores. Já os outros três métodos de precipitação proporcionaram um aumento muito maior no número e quantidade de proteínas que foram separadas em grupos distintos e bem distribuídos pelo gel. O método de precipitação com acetona destaca-se por apresentar spots bem maiores, caracterizando menor perda de proteínas durante esta etapa de preparo, o que é desejável para estudo de proteomas totais. Além disso, este método possibilitou a detecção de um número maior de diferentes proteínas localizadas na região central do gel. Sendo assim, o método de precipitação com acetona foi o escolhido para continuação do processo de otimização do método.

Outra amostra foi purificada por diálise em membrana com cut off de $1 \mathrm{kDa}$, realizada durante 18-20 h, e liofilizada. Como pode ser visto na Figura 5, este método foi igualmente eficaz para o preparo de proteínas de músculo. Da mesma forma que para a precipitação com acetona, as amostras dialisadas e liofilizadas apresentaram um número considerável de spots, inclusive na região central do gel. Além disso, considerando que a separação de todos os géis tenha sido feita seguindo sempre os mesmos parâmetros, somente mudando o modo de eliminação de interferentes das amostras, é visível o ganho de resolução dos spots no gel de amostras dialisadas. Esta evolução pode ser uma consequência de uma eliminação mais eficiente de interferentes que prejudicam a IEF. Desta forma, optou-se pela diálise seguida de liofilização, pois este método garantiu resultados apropriados de purificação e concentração das proteínas, sendo até mais eficiente que o método clássico de precipitação por acetona. Um fator que foi igualmente importante para a decisão final na seleção do método de diálise é que nas próximas etapas da pesquisa seria enfatizada a análise somente de glicoproteínas 
presentes nas amostras, e até o momento não havia dados a respeito da seletividade de precipitação desta classe de proteínas por acetona. Também para prevenir sua perda durante esta etapa de preparo, a diálise foi escolhida, pois este método é baseado basicamente na restrição por tamanho, dependendo da membrana escolhida.

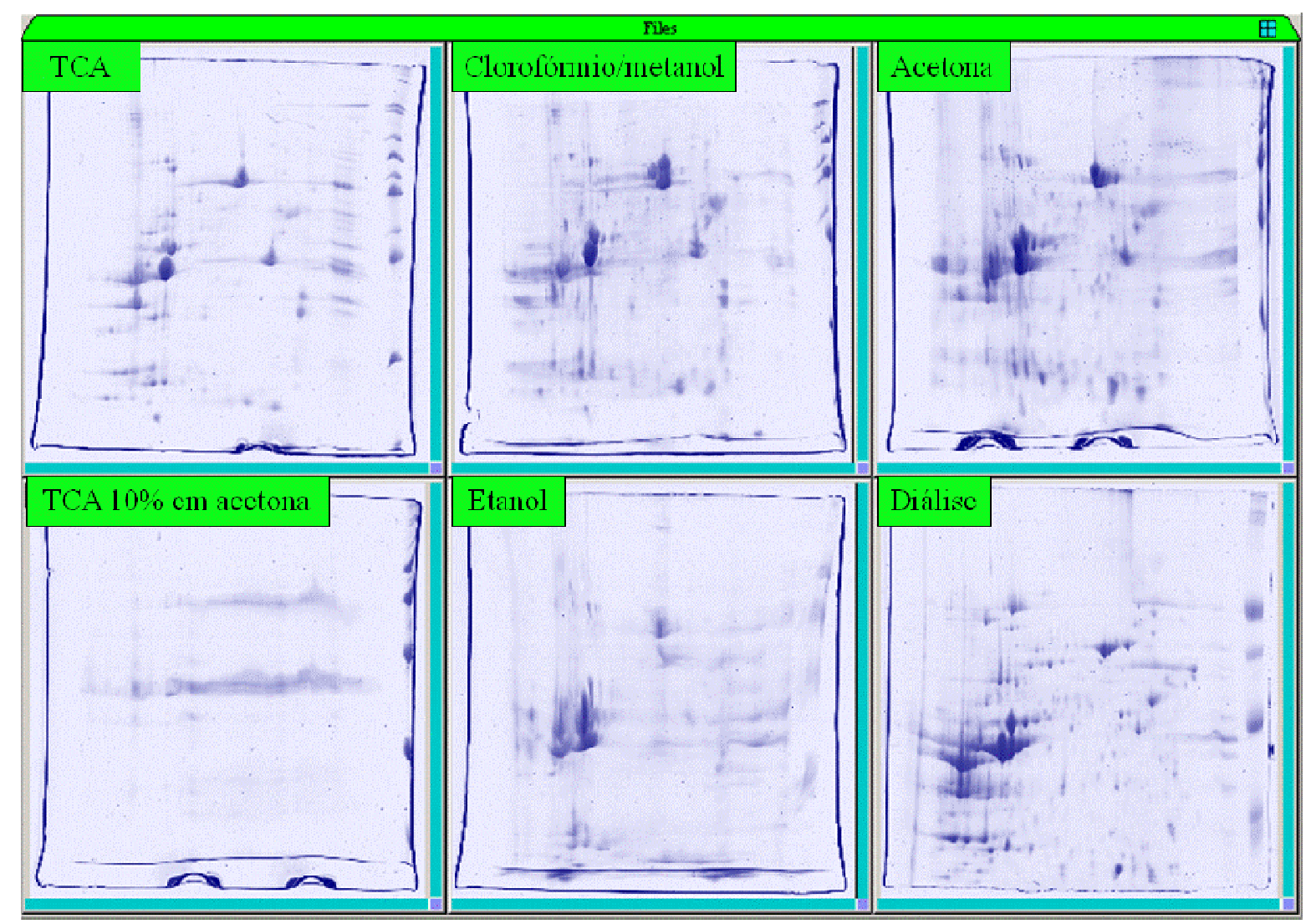

Figura 2.6 - Géis das amostras purificadas por precipitação ou diálise seguida por liofilização. Condições: fitas com intervalo de pH 3-10 não linear (3-10 NL) de $7 \mathrm{~cm}$ de comprimento. Para a segunda dimensão, foram empregados géis de poliacrilamida 10\%. Região básica dos géis sempre à esquerda. Amostras: gastrocnêmio de camundongo controle.

\subsubsection{Pré-purificação das glicoproteínas por WGA}

Como já citado anteriormente na introdução deste capítulo, existem diferentes formas de fracionamento de proteínas, dependendo de suas características estruturais. No caso de glicoproteínas, que é o alvo principal deste estudo, o uso de lectinas pode auxiliar na 
eliminação de proteínas interferentes, diminuindo a complexidade da amostra e facilitando sua detecção e identificação.

A lectina escolhida para a seleção das glicoproteínas neste trabalho foi a WGA, pois esta tem sido bastante utilizada para o enriquecimento da $\alpha$-DG. Visto que um dos objetivos de estudo é verificar a diferença de glicosilação entre animais controle e LARGE, a seleção da WGA para purificação das glicoproteínas garante o enriquecimento não somente da $\alpha$-DG, como também de outras glicoproteínas que possuam resíduos de oligossacarídeos estruturalmente semelhantes aos presentes nesta glicoproteína.

A WGA succinilada é uma proteína ácida com valor de pI em torno de 4,0. Já a WGA nativa é uma proteína básica, com pI 8,5. A WGA nativa se liga a glicoconjugados que contêm $\mathrm{N}$-acetilglucosamina, seu dissacarídeo di-N-acetilchitobiose, e ao ácido $\mathrm{N}$ acetilneuramínico, enquanto que a WGA succinilada se liga a glicoconjugados contendo apenas os dois primeiros resíduos citados. ${ }^{31,32}$

A homogeneização dos tecidos musculares foi realizada na presença de Triton X-100, contribuindo assim para a solubilização de proteínas mais hidrofóbicas, tais como proteínas da membrana, e não apenas as hidrofílicas. ${ }^{33}$ A fim de impedir a precipitação das proteínas durante os passos subsequentes de preparo da amostra, uma porcentagem menor $(0,1 \% \mathrm{v} / \mathrm{v})$ deste agente tensoativo não iônico foi também adicionada aos tampões utilizados durante a purificação com WGA, porém sem prejuízo da interação de lectina-glicoproteína.

\subsubsection{Quantificação das proteínas}

Dois métodos de quantificação foram comparados durante o preparo de amostra, a fim de determinar com maior precisão a concentração de proteínas presentes nas amostras totais e nas purificadas por WGA e, consequentemente, a quantidade de proteínas aplicadas à 2-DE. $\mathrm{O}$ primeiro método utilizado foi o de Bradford. ${ }^{21}$ Por Bradford, as amostras purificadas por WGA apresentaram valores de concentração comparáveis à do solvente (sugerindo a inexistência de proteínas em solução), enquanto que as amostras não purificadas geraram resultados adequados à quantidade de tecido muscular utilizada para a extração. Estes resultados corroboram com dados da literatura, e prova que o método de Bradford subestima a 
concentração de glicoproteínas. ${ }^{34} \mathrm{O}$ corante Coomassie blue, que é utilizado neste ensaio, liga-se às proteínas por interações hidrofóbicas e iônicas. A presença de oligossacarídeos ligados à cadeia peptídica pode alterar a hidrofobicidade da proteína e/ou representar um obstáculo estérico, impedindo a interação entre o corante e os aminoácidos ao qual se liga, ou seja, arginina e lisina. ${ }^{34,35}$

O método de quantificação testado em seguida com ambas as amostras foi o BCA. ${ }^{22}$ Embora este método também não seja 100\% preciso para quantificação de glicoproteínas, ele foi adequado para a detecção nas amostras, mesmo após a utilização da coluna de WGA. Com o ensaio de BCA, a concentração de amostras de proteínas purificadas, se comparada com a concentração das amostras originais antes da purificação, foi cerca de 50\%. Este ensaio foi, portanto, escolhido para a determinação da concentração das amostras antes de sua inserção nas fitas de IEF.

\subsubsection{2-DE e MS}

As análises de 2-DE das amostras purificadas por WGA requereu mudanças em alguns parâmetros analíticos, devido ao fato das proteínas por ela purificadas interagirem de uma maneira diferenciada com os reagentes utilizados para coloração dos spots no gel. Desta forma, houve a necessidade de aumentar a quantidade de proteínas inseridas nas fitas de IEF, garantindo assim sua visualização. Com isso, os parâmetros de focalização também tiveram que ser modificados para garantir uma separação completa de toda a amostra. A voltagem total acumulada foi aumentada para $8000 \mathrm{Vh}$ e, consequentemente, houve também um aumento no tempo total de focalização.

A quantidade de proteína escolhida inicialmente para inserção nas fitas de IEF foi de $100 \mu \mathrm{g}$, entretanto os sinais das proteínas purificadas por WGA ficaram muito fracos no gel, mesmo após coloração com nitrato de prata. Após vários testes, a quantidade de amostra escolhida para separação por 2-DE foi de $1 \mathrm{mg}$. A Figura 2.7 ilustra 3 géis de amostras de músculo gastrocnêmio preparados e corados por Coomassie blue. É possível notar uma semelhança no padrão de proteínas separadas no gel de proteínas totais e no gel de proteínas não ligadas à WGA, as quais foram lavadas da coluna antes da eluição das proteínas de 
interesse. A região básica do gel de proteínas totais apresentou a maior parte das proteínas abundantes na amostra, e com a purificação por WGA, foi possível eliminá-las eficientemente, através da lavagem da fase antes da eluição final. Entretanto, mesmo com a inserção de $1 \mathrm{mg}$ de proteína na fita, poucas proteínas ligadas à WGA foram coradas por Coomassie.

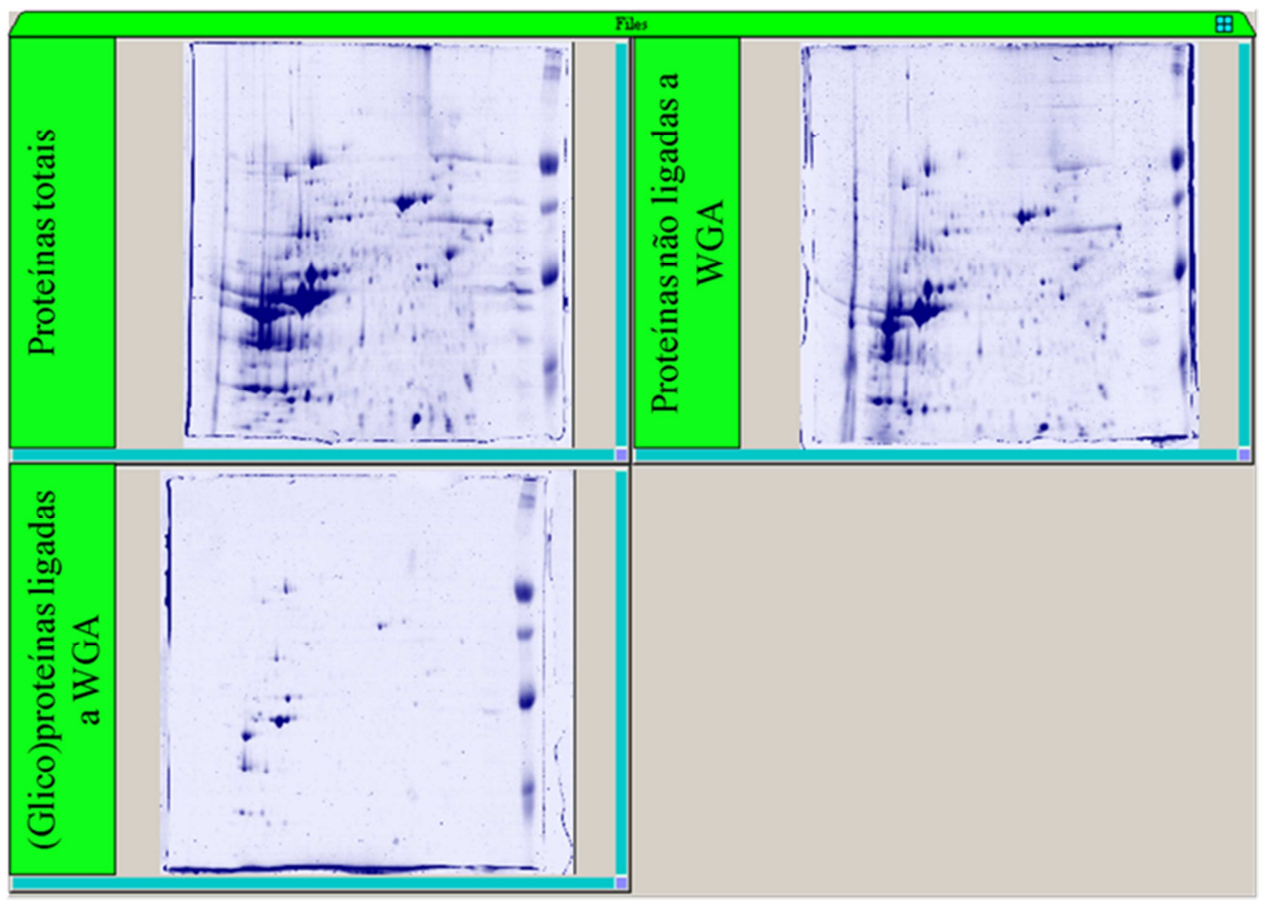

Figura 2.7 - Géis 2-D de proteínas extraídas de músculo gastrocnêmio de camundongo controle com 8 semanas de idade. Condições: fitas com intervalo de pH 3-10 não linear (3-10 NL) de $13 \mathrm{~cm}$ de comprimento. Para a segunda dimensão, foram empregados géis de poliacrilamida $8 \%$. Região básica dos géis sempre à esquerda. Amostras: proteínas totais sem pré-purificação; proteínas não ligadas à WGA (lavagem da coluna) e proteínas ligadas à WGA (eluição final).

Com os resultados dos géis 2-DE coloridos com Coomassie já obtidos, a duplicata do gel de proteínas ligadas à WGA foi colorido com nitrato de prata e comparado com o anterior. Os dois géis da mesma amostra estão ilustrados lado a lado na Figura 2.8. 


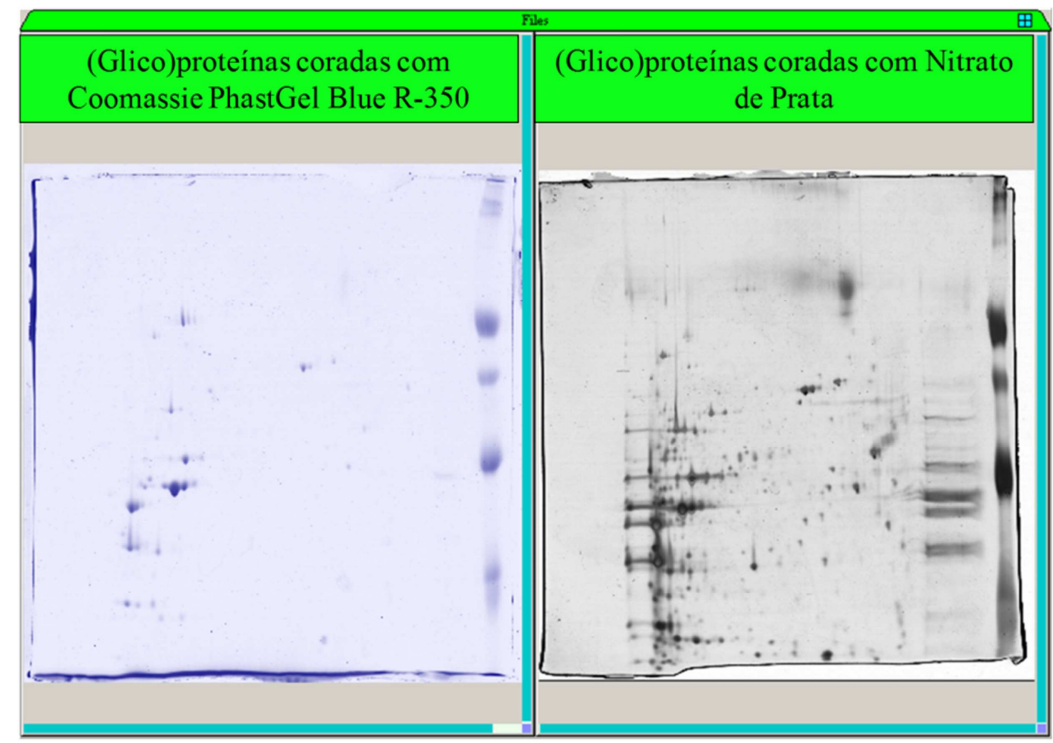

Figura 2.8 - Géis 2-DE de proteínas extraídas de músculo gastrocnêmio de camundongo controle com 8 semanas de idade. Condições: fitas com intervalo de pH 3-10 não linear (3-10 NL) de $13 \mathrm{~cm}$ de comprimento. Para a segunda dimensão, foram empregados géis de poliacrilamida 8\%. Região básica dos géis sempre à esquerda. Amostras: proteínas ligadas à WGA (eluição final). Gel colorido com Coomassie à esquerda (mesmo gel ilustrado na Figura 2.7) e com nitrato de prata à direita.

O gel corado com prata, das proteínas fracionadas por WGA (Figura 2.8), apresentou spots intensos mas sem saturação que pudesse impedir a análise proteômica, mesmo com a aplicação de $1 \mathrm{mg}$ de proteína. Como já descrito anteriormente, o gel da mesma amostra corado com Coomassie apresentou apenas um pequeno número de spots visíveis, a maioria na região básica do gel. Comparando este resultado com o do gel colorido com nitrato de prata, é notável o aumento no número de spots visíveis em todas as regiões do gel.

Para conhecer a classe de proteínas identificáveis nos diferentes géis apresentados, todos os spots visíveis foram recortados e as proteínas foram digeridas in-gel. Este procedimento somente não foi realizado com o gel das proteínas não ligadas à WGA (Figura 2.7). As análises de MS/MS dos peptídeos digeridos a partir dos três demais géis foram realizadas, e um total de 88 spots foram positivamente identificados (cada spot foi digerido e analisado por LC-MS/MS separadamente). As informações sobre estas proteínas estão dispostas na Tabela 2.5, e cada spot identificado foi enumerado nesta Tabela e nos géis da Figura 2.9. Cabe salientar que os géis apresentados na Figura 2.9 são os mesmos géis das Figuras 2.7 e 2.8 anteriores, somente repetidos para facilitar a avaliação dos resultados de MS. 



Figura 2.9 - Proteínas extraídas de músculo gastrocnêmio de camundongo controle com 8 semanas de idade, separadas por 2-DE. Condições: fitas com intervalo de pH 3-10 não linear (3-10 NL) de $13 \mathrm{~cm}$ de comprimento. Para a segunda dimensão, foram empregados géis de poliacrilamida 8\%. A) amostra pré-purificada por WGA e corada com nitrato de prata. B) amostra pré-purificada por WGA e corada com coomassie blue. C) amostra total sem pré-puificação e corada com coomassie blue. Os spots enumerados foram identificados por MS. 
Tabela 2.5 - Identificação das proteínas enumeradas na Figura 2.8.

\begin{tabular}{|c|c|c|c|c|c|c|c|}
\hline $\begin{array}{c}\text { Nome de entrada } \\
\text { (UniProtKB)/ } \\
\text { (n⿳o do spot) }\end{array}$ & MM & $\begin{array}{l}\text { MM } \\
\text { (gel) }\end{array}$ & pI teórico & pI (gel) & $\begin{array}{c}\text { Cobertura da } \\
\text { sequência peptídica }\end{array}$ & $\begin{array}{c}\text { Números de } \\
\text { peptídeos } \\
\text { encontrados }\end{array}$ & MPD * \\
\hline MIME_MOUSE (1) & 34333 & 82099 & 5.5 & 8.9 & $8 \%$ & 5 & Ponte dissulfeto; glicoproteína \\
\hline TNNI2_MOUSE (2) & 21344 & 72531 & 8.7 & 8.9 & $13 \%$ & 3 & \\
\hline TOP1_MOUSE (3) & 91275 & 73453 & 9.4 & 8.3 & $4 \%$ & 9 & $\begin{array}{l}\text { Acetilação; ligação isopeptídica; fosfoproteína; } \\
\text { conjugação ubl }\end{array}$ \\
\hline ALDOA_MOUSE (4) & 39787 & 37349 & 8.3 & 8.4 & $12 \%$ & 3 & Acetilação; nitração; fosfoproteína \\
\hline G3P_MOUSE (5) & 36072 & 32706 & 8.4 & 8.3 & $15 \%$ & 3 & $\begin{array}{l}\text { Ribosilação ADP; acetilação; metilação; } \\
\text { fosfoproteína; nitrosilação-s; conjugação ubl }\end{array}$ \\
\hline KCRM_MOUSE (6) & 43246 & 39371 & 6.6 & 7.9 & $35 \%$ & 12 & \\
\hline ENOB_MOUSE (7) & 47337 & 43909 & 6.7 & 7.8 & $9 \%$ & 2 & \\
\hline PTRF_MOUSE (8) & 43927 & 43869 & 5.4 & 7.5 & $8 \%$ & 8 & Acetilação; fosfoproteína \\
\hline KCRM_MOUSE (9) & 43246 & 44703 & 6.6 & 7.6 & $11 \%$ & 3 & \\
\hline SYTL2_MOUSE (10) & 107196 & 45000 & 6.1 & 8.5 & $2 \%$ & 6 & Fosfoproteína \\
\hline SNUT1_MOUSE (11) & 91001 & 52915 & 5.7 & 8.9 & $3 \%$ & 6 & Fosfoproteína; conjugação ubl \\
\hline RSPO2_MOUSE (12) & 29682 & 43829 & 9.4 & 8.9 & $9 \%$ & 5 & Ponte dissulfeto; glicoproteína \\
\hline RRS1_MOUSE (13) & 41526 & 37451 & 10.8 & 8.9 & $9 \%$ & 7 & Acetilação; fosfoproteína \\
\hline COX42_MOUSE (14) & 20364 & 38732 & 9.5 & 8.3 & $15 \%$ & 5 & Ponte dissulfeto \\
\hline FACR2_MOUSE (15) & 59528 & 55744 & 9.3 & 5.5 & $5 \%$ & 7 & \\
\hline ING5_MOUSE (16) & 28294 & 28902 & 7.6 & 8.2 & $15 \%$ & 8 & Acetilação; fosfoproteína \\
\hline RL6_MOUSE (17) & 33546 & 22938 & 10.7 & 5.6 & $10 \%$ & 6 & Acetilação; fosfoproteína \\
\hline CC130_MOUSE (18) & 44309 & 26104 & 8.3 & 8.8 & $10 \%$ & 10 & Fosfoproteína \\
\hline PRP4B_MOUSE (19) & 117304 & 83989 & 10.2 & 8.4 & $5 \%$ & 11 & Acetilação; fosfoproteína \\
\hline
\end{tabular}


(continuação) Tabela 2.5 - Identificação das proteínas enumeradas na Figura 2.8.

\begin{tabular}{|c|c|c|c|c|c|c|c|}
\hline $\begin{array}{c}\text { Nome de entrada } \\
\text { (UniProtKB)/ } \\
\left(n^{0} \text { do spot }\right)\end{array}$ & MM & $\begin{array}{l}\text { MM } \\
\text { (gel) }\end{array}$ & pI teórico & pI (gel) & $\begin{array}{c}\text { Cobertura da } \\
\text { sequência peptídica }\end{array}$ & $\begin{array}{c}\text { Números de } \\
\text { peptídeos } \\
\text { encontrados }\end{array}$ & MPD * \\
\hline SSRP1_MOUSE (20) & 81152 & 85273 & 6.3 & 8.3 & $3 \%$ & 5 & Acetilação; fosfoproteína; conjugação ubl \\
\hline KPYM_MOUSE (21) & 58378 & 52425 & 7.2 & 8.1 & $2 \%$ & 1 & $\begin{array}{l}\text { Acetilação; hidroxilação; fosfoproteína; conjugação } \\
\text { ubl }\end{array}$ \\
\hline ENOB_MOUSE (22) & 47337 & 44132 & 6.7 & 7.8 & $18 \%$ & 5 & $\begin{array}{l}\text { Acetilação; hidroxilação; fosfoproteína; conjugação } \\
\text { ubl }\end{array}$ \\
\hline KCRM_MOUSE (23) & 43246 & 40147 & 6.6 & 7.8 & $37 \%$ & 9 & \\
\hline KCRM_MOUSE (24) & 43246 & 39776 & 6.6 & 8.0 & $53 \%$ & 18 & \\
\hline ALDOA_MOUSE (25) & 39787 & 37171 & 8.3 & 8.7 & $31 \%$ & 6 & Acetilação; nitração; fosfoproteína \\
\hline ALDOA_MOUSE (26) & 39787 & 37171 & 8.3 & 8.7 & $34 \%$ & 10 & Acetilação; nitração; fosfoproteína \\
\hline G3P_MOUSE (27) & 36072 & 32795 & 8.4 & 8.8 & $26 \%$ & 5 & $\begin{array}{l}\text { Ribosilação ADP; acetilação; metilação; } \\
\text { fosfoproteína; nitrosilação-s; conjugação ubl }\end{array}$ \\
\hline LDHA_MOUSE (28) & 36817 & 32102 & 7.6 & 8.3 & $6 \%$ & 2 & Acetilação; fosfoproteína; conjugação ubl \\
\hline PGAM2_MOUSE (29) & 28980 & 26395 & 8.7 & 8.8 & $11 \%$ & 2 & Ligação isopeptídica; fosfoproteína; conjugação ubl \\
\hline TPIS_MOUSE (30) & 32684 & 25105 & 5.6 & 8.2 & $13 \%$ & 2 & Acetilação; nitração; fosfoproteína \\
\hline AT2A1_MOUSE (31) & 110723 & 126772 & 5.1 & 5.1 & $8 \%$ & 5 & Ponte dissulfeto; fosfoproteína \\
\hline ALBU_MOUSE (32) & 70700 & 61692 & 5.8 & 5.8 & $8 \%$ & 4 & $\begin{array}{l}\text { Clivagem em pares de resíduos básicos; ponte } \\
\text { dissulfeto; fosfoproteína }\end{array}$ \\
\hline KAD1_MOUSE (33) & 21640 & 23244 & 5.7 & 5.5 & $13 \%$ & 2 & Acetilação \\
\hline TERA_MOUSE (34) & 89950 & 100673 & 5.1 & 5.2 & $6 \%$ & 3 & Acetilação; fosfoproteína; conjugação ubl \\
\hline HSP7C_MOUSE (35) & 71055 & 63762 & 5.4 & 5.4 & $10 \%$ & 5 & Acetilação; fosfoproteína; conjugação ubl \\
\hline ALBU_MOUSE (36) & 70700 & 60882 & 5.8 & 5.7 & $6 \%$ & 3 & $\begin{array}{l}\text { Clivagem em pares de resíduos básicos; ponte } \\
\text { dissulfeto; fosfoproteína }\end{array}$ \\
\hline ALBU_MOUSE (37) & 70700 & 59802 & 5.8 & 5.8 & $15 \%$ & 7 & Clivagem em pares de resíduos básicos; ponte \\
\hline
\end{tabular}


(continuação) Tabela 2.5 - Identificação das proteínas enumeradas na Figura 2.8.

\begin{tabular}{|c|c|c|c|c|c|c|c|}
\hline $\begin{array}{l}\text { Nome de entrada } \\
\text { (UniProtKB }) / \\
\left(n^{\circ} \text { do spot }\right)\end{array}$ & MM & $\begin{array}{l}\text { MM } \\
\text { (gel) }\end{array}$ & pI teórico & pI (gel) & $\begin{array}{c}\text { Cobertura da } \\
\text { sequência peptídica }\end{array}$ & $\begin{array}{l}\text { Números de } \\
\text { peptídeos } \\
\text { encontrados }\end{array}$ & MPD * \\
\hline ALBU_MOUSE (38) & 70700 & 59901 & 5.8 & 5.9 & $29 \%$ & 20 & $\begin{array}{l}\text { dissulfeto; fosfoproteína } \\
\text { Clivagem em pares de resíduos básicos; ponte } \\
\text { dissulfeto; fosfoproteína }\end{array}$ \\
\hline PDIA1_MOUSE (39) & 57422 & 53478 & 4.8 & 4.6 & $5 \%$ & 1 & Ponte dissulfeto \\
\hline CASQ1_MOUSE (40) & 46349 & 56160 & 4.0 & 4.9 & $5 \%$ & 1 & Glicoproteína \\
\hline ATPB_MOUSE (41) & 56265 & 48556 & 5.2 & 4.9 & $53 \%$ & 22 & Acetilação; fosfoproteína \\
\hline ATPB_MOUSE (42) & 56265 & 49365 & 5.2 & 4.8 & $27 \%$ & 10 & Acetilação; fosfoproteína \\
\hline ACTA_MOUSE (43) & 42381 & 43536 & 5.2 & 5.2 & $26 \%$ & 8 & Acetilação; metilação; oxidação fosfoproteína \\
\hline QCR1_MOUSE (44) & 53446 & 46823 & 5.8 & 5.5 & $13 \%$ & 7 & Acetilação; fosfoproteína \\
\hline PYGM_MOUSE (45) & 97681 & 95483 & 6.7 & 7.8 & $17 \%$ & 11 & Acetilação; fosfoproteína \\
\hline PYGM_MOUSE (46) & 97681 & 102376 & 6.7 & 7.8 & $19 \%$ & 10 & Acetilação; fosfoproteína \\
\hline PYGM_MOUSE (47) & 97681 & 102376 & 6.7 & 7.8 & $7 \%$ & 3 & Acetilação; fosfoproteína \\
\hline ACON_MOUSE (48) & 86151 & 83527 & 8.1 & 8.4 & $11 \%$ & 5 & $\begin{array}{l}\text { Acetilação; ligação isopeptídica; ácido pirrolidona } \\
\text { carboxílico; conjugação ubl }\end{array}$ \\
\hline PGM1_MOUSE (49) & 61665 & 56300 & 6.1 & 7.5 & $14 \%$ & 5 & Acetilação; fosfoproteína \\
\hline PGM1_MOUSE (50) & 61665 & 56580 & 6.1 & 7.1 & $17 \%$ & 7 & Acetilação; fosfoproteína \\
\hline KPYM_MOUSE (51) & 58378 & 52828 & 7.2 & 8.1 & $23 \%$ & 9 & Acetilação; hidroxilação; fosfoproteína \\
\hline KPYM_MOUSE (52) & 58378 & 53134 & 7.2 & 8.0 & $13 \%$ & 5 & Acetilação; hidroxilação; fosfoproteína \\
\hline KPYM_MOUSE (53) & 58378 & 53443 & 7.2 & 7.8 & $6 \%$ & 2 & Acetilação; hidroxilação; fosfoproteína \\
\hline DLDH_MOUSE (54) & 54751 & 52220 & 8.0 & 7.8 & $5 \%$ & 2 & Acetilação; ponte dissulfeto; fosfoproteína \\
\hline ATPA_MOUSE (55) & 59830 & 48396 & 9.2 & 8.4 & $10 \%$ & 3 & $\begin{array}{l}\text { Acetilação; fosfoproteína; ácido pirrolidona } \\
\text { carboxílico }\end{array}$ \\
\hline ENOB_MOUSE (56) & 47337 & 44746 & 6.7 & 7.9 & $44 \%$ & 20 & Acetilação; fosfoproteína; conjugação ubl \\
\hline ENOB_MOUSE (57) & 47337 & 44703 & 6.7 & 7.6 & $18 \%$ & 5 & Acetilação; fosfoproteína; conjugação ubl \\
\hline
\end{tabular}


(continuação) Tabela 2.5 - Identificação das proteínas enumeradas na Figura 2.8.

\begin{tabular}{|c|c|c|c|c|c|c|c|}
\hline $\begin{array}{c}\text { Nome de entrada } \\
\text { (UniProtKB)/ } \\
\left(n^{0} \text { do spot) }\right.\end{array}$ & MM & $\begin{array}{l}\text { MM } \\
\text { (gel) }\end{array}$ & pI teórico & pI (gel) & $\begin{array}{c}\text { Cobertura da } \\
\text { sequência peptídica }\end{array}$ & $\begin{array}{c}\text { Números de } \\
\text { peptídeos } \\
\text { encontrados }\end{array}$ & MPD * \\
\hline ENOB_MOUSE (58) & 47337 & 45486 & 6.7 & 7.4 & $11 \%$ & 2 & Acetilação; fosfoproteína; conjugação ubl \\
\hline KCRM_MOUSE (59) & 43246 & 40213 & 6.6 & 8.1 & $61 \%$ & 39 & \\
\hline KCRM_MOUSE (60) & 43246 & 40061 & 6.6 & 7.9 & $52 \%$ & 27 & \\
\hline KCRM_MOUSE (61) & 43246 & 40404 & 6.6 & 7.7 & $35 \%$ & 13 & \\
\hline KCRM_MOUSE (62) & 43246 & 40826 & 6.6 & 7.6 & $18 \%$ & 5 & \\
\hline KCRS_MOUSE (63) & 47899 & 39910 & 8.6 & 8.6 & $17 \%$ & 4 & \\
\hline PGK1_MOUSE (64) & 44921 & 41409 & 8.0 & 8.5 & $6 \%$ & 2 & Acetilação; fosfoproteína \\
\hline ENOB_MOUSE (65) & 47337 & 45112 & 6.7 & 8.2 & $11 \%$ & 2 & Acetilação; fosfoproteína; conjugação ubl \\
\hline ALDOA_MOUSE (66) & 39787 & 37497 & 8.3 & 9.0 & $64 \%$ & 24 & Acetilação; nitração; fosfoproteína \\
\hline ALDOA_MOUSE (67) & 39787 & 37249 & 8.3 & 8.8 & $63 \%$ & 21 & Acetilação; nitração; fosfoproteína \\
\hline ALDOA_MOUSE (68) & 39787 & 37179 & 8.3 & 8.7 & $49 \%$ & 16 & Acetilação; nitração; fosfoproteína \\
\hline ALDOA_MOUSE (69) & 39787 & 37568 & 8.3 & 9.2 & $27 \%$ & 6 & Acetilação; nitração; fosfoproteína \\
\hline ALDOA_MOUSE (70) & 39787 & 37960 & 8.3 & 9.3 & $19 \%$ & 4 & Acetilação; nitração; fosfoproteína \\
\hline G3P_MOUSE (71) & 36072 & 32602 & 8.4 & 9.2 & $45 \%$ & 13 & $\begin{array}{l}\text { Ribosilação ADP; acetilação; metilação; } \\
\text { fosfoproteína; nitrosilação-s; conjugação ubl }\end{array}$ \\
\hline G3P_MOUSE (72) & 36072 & 32295 & 8.4 & 9.0 & $36 \%$ & 12 & $\begin{array}{l}\text { Ribosilação ADP; acetilação; metilação; } \\
\text { fosfoproteína; nitrosilação-s; conjugação ubl }\end{array}$ \\
\hline G3P_MOUSE (73) & 36072 & 32849 & 8.4 & 9.3 & $15 \%$ & 3 & $\begin{array}{l}\text { Ribosilação ADP; acetilação; metilação; } \\
\text { fosfoproteína; nitrosilação-s; conjugação ubl }\end{array}$ \\
\hline MDHM_MOUSE (74) & 36045 & 34083 & 8.9 & 9.2 & $12 \%$ & 2 & Acetilação; fosfoproteína \\
\hline G3P_MOUSE (75) & 36072 & 33287 & 8.4 & 9.4 & $22 \%$ & 4 & $\begin{array}{l}\text { Ribosilação ADP; acetilação; metilação; } \\
\text { fosfoproteína; nitrosilação-s; conjugação ubl }\end{array}$ \\
\hline G3P_MOUSE (76) & 36072 & 33161 & 8.4 & 9.6 & $32 \%$ & 6 & $\begin{array}{l}\text { Ribosilação ADP; acetilação; metilação; } \\
\text { fosfoproteína; nitrosilação-s; conjugação ubl }\end{array}$ \\
\hline
\end{tabular}


(continuação) Tabela 2.5 - Identificação das proteínas enumeradas na Figura 2.8.

\begin{tabular}{|c|c|c|c|c|c|c|c|}
\hline $\begin{array}{c}\text { Nome de entrada } \\
\text { (UniProtKB)/ } \\
\left(n^{-} \text {do spot }\right)\end{array}$ & $\mathbf{M M}$ & $\begin{array}{l}\text { MM } \\
\text { (gel) }\end{array}$ & pI teórico & pI (gel) & $\begin{array}{c}\text { Cobertura da } \\
\text { sequência peptídica }\end{array}$ & $\begin{array}{c}\text { Números de } \\
\text { peptídeos } \\
\text { encontrados }\end{array}$ & MPD * \\
\hline LDHA_MOUSE (77) & 36817 & 31841 & 7.6 & 8.4 & $28 \%$ & 7 & Acetilação; fosfoproteína; conjugação ubl \\
\hline LDHA_MOUSE (78) & 36817 & 32664 & 7.6 & 8.1 & $11 \%$ & 3 & Acetilação; fosfoproteína; conjugação ubl \\
\hline CAH3_MOUSE (79) & 29633 & 26431 & 6.9 & 8.5 & $29 \%$ & 5 & Glutationilação \\
\hline PGAM2_MOUSE (80) & 28980 & 26183 & 8.7 & 8.8 & $33 \%$ & 6 & Ligação isopeptídica; fosfoproteína; conjugação ubl \\
\hline PGAM2_MOUSE (81) & 28980 & 26531 & 8.7 & 9.2 & $45 \%$ & 11 & Ligação isopeptídica; fosfoproteína; conjugação ubl \\
\hline GSTM1_MOUSE (82) & 26067 & 23530 & 7.7 & 8.9 & $7 \%$ & 1 & Fosfoproteína \\
\hline TPIS_MOUSE (83) & 32684 & 24998 & 5.6 & 8.3 & $16 \%$ & 4 & Acetilação; nitração; fosfoproteína \\
\hline TPIS_MOUSE (84) & 32684 & 25523 & 5.6 & 7.8 & $31 \%$ & 7 & Acetilação; nitração; fosfoproteína \\
\hline CAH3_MOUSE (85) & 29633 & 26632 & 6.9 & 8.2 & $24 \%$ & 3 & Glutationilação \\
\hline TPIS_MOUSE (86) & 32684 & 25187 & 5.6 & 7.7 & $11 \%$ & 3 & Acetilação; nitração; fosfoproteína \\
\hline TPIS_MOUSE (87) & 32684 & 25283 & 5.6 & 7.5 & $13 \%$ & 2 & Acetilação; nitração; fosfoproteína \\
\hline KAD1_MOUSE (88) & 21640 & 22938 & 5.7 & 5.6 & $64 \%$ & 15 & Acetilação \\
\hline
\end{tabular}

* Modificação pós-traducional. 
Conforme já esperado, proteínas abundantes como albumina do soro (ALBU_MOUSE), creatina quinase (KCRM_MOUSE) e frutose-bifosfato-aldolase A (ALDOA_MOUSE) foram identificadas no gel de amostra total, e compreendem os spots mais intensos. A presença de grandes quantidades dessas proteínas pode ocultar as que estão em menores quantidades nas mesmas regiões do gel. Não só a visualização destas proteínas menos abundantes fica dificultada, como também a análise de seus peptídeos por MS, pois estes são facilmente suprimidos pelos sinais dos peptídeos existentes em maiores concentrações na amostra. Os géis A e B da Figura 2.9, por outro lado, mostram um padrão de proteínas quase que completamente livre destes interferentes. Isso se deve ao fato de as proteínas mais abundantes terem sido eliminadas graças à etapa de cromatografia de lectina, permitindo a identificação de outras proteínas presentes na mesma região (das mais abundantes) do gel 2-D, mas que antes eram mascaradas. O diagrama de Venn na Figura 2.10 resume o número de proteínas encontradas em comum nos géis A, B e C da Figura 2.9.

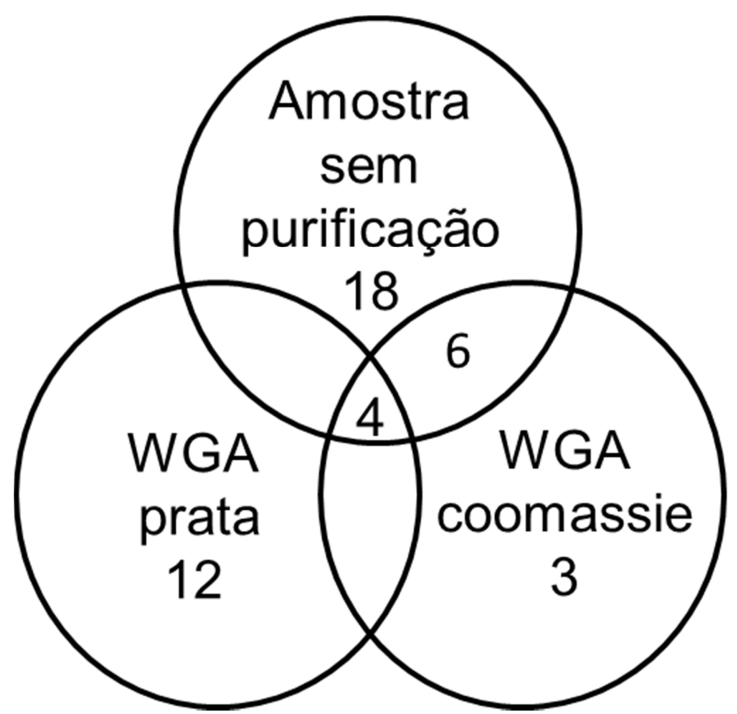

Figura 2.10 - Diagrama de Venn mostrando a sobreposição de proteínas identificadas nos géis ilustrados na Figura 2.9.

As proteínas ALDOA_MOUSE, KCRM_MOUSE, gliceraldeído-3-fosfato desidrogenase (G3P_MOUSE) e beta-enolase (ENOB_MOUSE) foram detectadas em todos os 3 géis. Seis proteínas foram encontradas em ambos os géis corados com Coomassie, entre os quais se inclui ALBU_MOUSE. Esta proteína abundante, no entanto, não foi detectada no gel corado com prata. É interessante notar que nenhuma proteína foi identificada em comum somente entre os géis das amostras purificadas por WGA mas coradas de maneiras diferentes 
(géis A e B da Figura 2.9). De todas as proteínas visualizadas com nitrato de prata, apenas duas delas, a DNA topoisomerase 1 (TOP1_MOUSE) e a proteína homóloga reguladora da biogênese ribossomal (RRS1_MOUSE) possuem regiões ricas em lisina e/ou arginina, de acordo com a Base de Conhecimento UniProtKB. Este fator estrutural pode ser uma razão para os spots encontrados no gel de prata estarem ausentes no gel corado com Coomassie, uma vez que este corante tem grande afinidade para resíduos de lisina e arginina. ${ }^{34,35}$ Além disso, a baixa quantidade dessas proteínas coradas apenas com prata também poderia ser uma explicação para os resultados observados.

De todas as proteínas identificadas neste experimento, apenas três delas apresentaram glicosilação como uma PTM possível (spots $\mathrm{n}^{\circ}$ 1, 12 e 40, sendo que os dois primeiros foram encontrados no gel corado com prata), nenhuma sendo glicoproteína com alto grau de glicosilação. Mesmo assim, não é possível afirmar que nenhuma proteína altamente glicosilada foi colorida por ambos os métodos testados, porque muitos spots visíveis não puderam ser atribuídos a proteínas específicas, devido aos baixos valores de score obtidos nas buscas pelo Mascot. Este resultado pode ser consequência de uma tripsinização incompleta, resultando em peptídeos com massas diferentes das esperadas para este tipo de digestão, ou mesmo a presença de estruturas de oligossacarídeos ligadas a certos peptídeos, que pode causar desvios em relação à massa esperada, fazendo com que a pesquisa no banco de dados se torne uma tarefa mais difícil. ${ }^{36,37}$ Mas não deve ser excluído também o fator impedimento estérico ocasionado pelos resíduos de oligossacaríeos, que afetam a coloração tanto por coomassie quanto por nitrato de prata, quando mais de $50 \%$ da massa molecular da glicoproteína é relativa aos carboidratos nela ligados. ${ }^{38,39} \mathrm{O}$ aumento da quantidade de amostra inserida nas fitas foi proposto como tentativa de minimizar este fator, pois uma quantidade maior de glicoproteína numa região específica do gel também representaria uma quantidade maior de peptídeos não glicosilados expostos para a reação com o corante. Entretanto, mesmo assim, em nenhum dos géis foi possível a identificação da $\alpha$-DG, em que aproximadamente $42 \%$ de sua massa total é referente ao resíduos de carboidratos nela ligados.

Das quinze proteínas identificadas exclusivamente nas amostras pré-purificadas por WGA (doze detectadas no gel corado com prata e as outras três no gel com Coomassie, conforme organizado no diagrama da Figura 2.10) duas delas, mesmo não sendo glicoproteínas, são citadas na literatura como ligantes de glicoproteínas em algum período de sua atividade no ser vivo. A proteína PRP4B_MOUSE (spot $\mathrm{n}^{\circ} 19$ ) pertence ao grupo de 
proteínas ricas em prolina (proline-rich proteins - PRP). Diversos tipos de mucinas interagem com PRPs, embora o sítio de interação ainda não tenha sido caracterizado. ${ }^{40}$ A proteína PTRF (spot $\mathrm{n}^{\circ}$ 8) tem sua distribuição afetada quando a expressão da glicoproteína $\beta$-DG é silenciada, interferindo na estruturação dos caveolaes (invaginações da membrana contendo domínios lipídicos). ${ }^{41} \mathrm{O}$ fato de estas proteínas serem ligantes de glicoproteínas pode ter contribuído para sua eluição juntamente com as demais glicoproteínas que se ligaram à WGA.

Um resultado que merece destaque neste estudo é a quantidade de spots detectados no gel de prata que não obtiveram cobertura da sequência peptídica suficiente para a identificação das respectivas proteínas. Esta quantidade é muito maior do que nos géis coloridos com Coomassie. Excluindo a possibilidade de isto ser consequência da glicosilação das cadeias peptídicas, como já discutido anteriormente, outros fatores podem ter contribuído para o fato observado. Um deles é a probabilidade de ter ocorrido reticulações nas proteínas devido à formação de pontes de metileno entre cadeias laterais reativas de alguns aminoácidos (lisina, cisteína ou até mesmo serina e treonina). Esta reação é altamente favorecida na presença de formaldeído (este reagente foi utilizado no protocolo de coloração aplicado, conforme citado na seção 2.3.6, Entretanto sua quantidade foi diminuida, em relação aos demais protocolos empregados para géis de poliacrilamida, para se adequar às análises de MS). A presença de prata residual também pode interferir nas análises de MS. Além disso, dados da literatura mostram que o simples fato de o gel ter ficado acondicionado por mais de 48 h em água antes dos processos de descoloração e digestão afetam os resultados de MS para identificação das proteínas. ${ }^{42}$

Existem alguns kits comerciais disponíveis para a detecção específica de glicoproteínas em géis de poliacrilamida, como os Pro-Q emerald 300 e 488 (Molecular Probes, Invitrogen, Carlsbad, CA, EUA), que diferem nos comprimentos de onda de emissão e excitação, e outros kits que funcionam baseados na interação glicoproteína-lectina. Entretanto, todos esses kits possuem um custo muito alto e requerem o uso de instrumentação específica para a documentação dos géis e visualização dos spots para excisão. O kit Pro-Q emerald 300 foi utilizado neste trabalho para a detecção das glicoproteínas fracionadas por WGA, num mini-gel com $200 \mu \mathrm{g}$ de proteínas separadas. Porém, várias dificuldades foram encontradas para a obtenção de resultados significativos. O tempo de duração do sinal de fluorescência foi muito curto para a documentação do gel e para o corte das regiões de interesse. Além do que a visualização dos spots a olho nu, mesmo numa cabine com luz 
ultravioleta (UV), se mostrou muito difícil, o que pode causar a omissão de vários spots que poderiam ser de interesse para o trabalho.

Até a presente data existem diversos artigos publicados relatando métodos de coloração por prata modificados ou em conjunto com outros corantes específicos para glicoproteínas. Como exemplo, Thierry Rabilloud e colegas ${ }^{43}$ desenvolveram um protocolo de coloração por prata livre de formaldeído, pela sua substituição por outros agentes redutores, como a aldose galactose. Com este protocolo, houve uma ligeira perda de sensibilidade na detecção das proteínas do gel, mas os resultados de MS foram mais favoráveis para sua identificação. Poulsen e Moller $^{44}$ obtiveram uma melhora considerável na detecção de glicoproteínas separadas por SDS-PAGE através do uso concomitante do método de coloração por ácido periódico/Alcian blue e nitrato de prata. Porém, eles não apresentaram resultados de análise dos peptídeos por MS que garantam a compatibilidade deste método de coloração com uma posterior análise de MS. 


\subsection{Conclusão}

Neste capítulo foram apresentados resultados que enfatizam a extrema importância da otimização de cada etapa de análise de proteínas por 2-DE. Os tampões utilizados para solubilização, o desenvolvimento de um protocolo de purificação ou fracionamento de amostra, assim como o método de coloração escolhido para visualização dos spots no gel geram resultados finais totalmente diferentes. Por isso é necessária a elaboração de protocolos específicos para cada interesse de estudo.

A abordagem 2-DE e MS não garantiu a identificação de proteínas altamente glicosiladas, mesmo com o fracionamento específico da amostra bruta por cromatografia de lectinas.

O campo da glicoproteômica ainda enfrenta muitas dificuldades para a detecção adequada desta classe de proteínas, e sua identificação por MS ainda é um desafio, principalmente quando do uso de bancos de dados teóricos para comparação com os resultados experimentais obtidos, devido tanto à digestão incompleta quanto pelos desvios de $\mathrm{m} / \mathrm{z}$ causados pelos resíduos de glicanas ligados aos peptídeos ionizados.

Algumas alternativas de protocolos de coloração de glicoproteínas foram publicados recentemente, e poderão ser futuramente testados para a detecção das proteínas de interesse neste estudo específico, em especial à $\alpha$-DG.

Apesar de as glicoproteínas alvo do estudo não terem sido identificadas nesta etapa, nada impede que futuramente as amostras de camundongos controle e LARGE, preparadas conforme descrito neste capítulo, sejam comparadas para verificação de expressão diferencial entre elas. Para isso, entretanto, é necessário o emprego de técnicas mais precisas para comparação quantitativa destas proteínas, como a eletroforese em gel diferencial bidimensional (2-D DIGE).

Outra alternativa para a análise dessas glicoproteínas pode ser o emprego de técnicas de separação em solução, como o fracionador Off-Gel, onde a separação é governada pela diferença de pI, e em seguida uma análise por LC-MS. Com esta abordagem as amostras podem ser digeridas antes da primeira etapa de fracionamento, selecionando, dessa forma, os peptídeos com características estruturais semelhantes (ácidos, básicos, glicosilados ou não). ${ }^{45}$ A cromatografia 2-D acoplada a um espectrômetro de massas também pode ser útil para a 
identificação de proteínas e glicoproteínas minoritárias, pois a complexidade da amostra diminui com esta estratégia de separação. Com a cromatografia 2-D, a separação das proteínas já digeridas (isto é, dos seus peptídeos) pode ser regida por mecanismos diferentes, dependendo da escolha das fases sólidas das colunas acopladas. ${ }^{46}$ Técnicas de separação em solução previnem a perda de peptídeos que potencialmente podem ficar retidos nos géis de poliacrilamida, aumentando assim a probabilidade de uma cobertura adequada de toda a sequência peptídica. 


\subsection{Bibliografia}

1. NOVOTNY, M. V.; SOINI, H. A.; MECHREF, Y. Journal of Chromatography B, v.866, p.26-47, 2008.

2. LÓPEZ, J. L. Journal of Chromatography B, v.849, p.190-202, 2007.

3. http://www.seed-proteome.com/vars/images/pub_defaut/2d\%20electrophoresis.jpg. Acesso em: 06 de Outubro de 2011.

4. WITTMANN-LIEBOLD, B.; GRAACK, H-R; POHL, T. Proteomics, v.6, p.46884703, 2006.

5. GÖRG, A.; WEISS, W.; DUNN, M. J. Proteomics, v.4, p.3665-3685, 2004.

6. http://www.gelifesciences.com/webapp/wcs/stores/servlet/catalog/en/GELifeSciences/ products/AlternativeProductStructure_16587/28933465. Acesso em: 23 de Dezembro de 2012.

7. http://www.creative-proteomics.com/2DE.htm. Acesso em: 23 de Dezembro de 2012.

8. http://www.ptsys.co.kr/kor/product_info/Ettan_IPGphor_IEF_System_01.htm. Acesso em: 23 de Dezembro de 2012.

9. ZHANG, Y.; GO, E. P.; DESAIRE, H. Analytical Chemistry, v.80, p.3144-3158, 2008.

10. PLAVINA, T.; WAKSHULL, E.; HANCOCK, W. S.; HINCAPIE, M. Journal of Proteome Research, v.6, p.662-671, 2007.

11. ORAZINE, C. I.; HINCAPIE, M.; HANCOCK, W. S.; HATTERSLEY, M.; HANKE, J. H. Journal of Proteome Research, v.7,p. 1542-1554, 2008. 
12. OLSEN, J. V.; ONG, S. E.; MANN, M. Molecular \& Cellular Proteomics, v.3.6, p.608-614, 2004.

13. CAÑAS, B.; FERRER, D. L.; FERNÁNDEZ, A. R.; CAMAFEITA, E.; CALVO, E. Briefings in functional genomics and proteomics, v.4 (4), p.295-320, 2006.

14. DOMON, B.; AEBERSOLD, R. Science, v.312, p.212-217, 2006.

15. ELIAS, J. E.; HAAS, W.; FAHERTY, B. K.; GYGI, S. P. Nature Methods, v.2 (9), p. $667-675,2005$.

16. EL-ANEED, A.; COHEN, A.; BANOUB, J. Applied Spectroscopy Reviews, v.44 (3), P.210-230, 2009.

17. FREITAS, M. A.; XU, H. Proteomics, v.9, p.1548-1555, 2009.

18. GREWAL, P. K.; HOLZFEIND, P. J.; BITTNER, R. E.; HEWITT, J. E. Nature Genetics, v.28, p.151-154, 2001.

19. MASUMI, N.; YASUE, A.; NISHIMATU, S.; NOHNO, T.; YAMAOKA, T.; ITAKURA, M.; MORIYAMA, K.; OHUCHI, H.; NOJI, S. Biochemical and Biophysical Research Communications, v.293 (1), p.247-251, 2002.

20. LIN, X.; LI, W.; LAI, J.; OKAZAKI, M.; SUGIMOTO, S.; YAMAMOTO, S.; WANG, X.; GELMAN, A. E.; KREISEL, D.; KRUPNICK, A. S. Journal of Thoracic Disease, v.4 (3), p.247-258, 2012.

21. BRADFORD, M. M. Analytical. Biochemistry, v.72, p.248-254, 1976.

22. SMITH, P. K.; KROHN, R. I.; HERMANSON, G. T.; MALLIA, A. K.; GARTNER, F. H.; PROVENZANO, M. D.; FUJIMOTO, E. K.; GOEKE, N. M.; OLSON, B. J.; KLENK, D. C. Analytical Biochemistry, v.150, p.76-85, 1985.

23. HAVLIS, J.; THOMAS, H.; SEBELA, M.; SHEVCHENKO, A. Analytical Chemistry, v.75, p.1300-1306, 2003. 
24. HELLMAN, U.; WERNSTEDT, C.; GÓÑEZ, J.; HELDIN, C-H. Analytical Biochemistry, v.224, p.451-455, 1995.

25. ROSENFELD, J.; CAPDEVIELLE, J.; GUILLEMOT, J. C.; FERRARA, P. Analytical Biochemistry, v.203, p.173-179, 1992.

26. HJELMELAND, L. M. Proceedings of the National Academy of Sciences of the United States of America, v.77 (11), p.6368-6370, 1980.

27. MAKINO, S.; REYNOLDS, J. A.; TANFORD, C. The Journal of Biological Chemistry, v.248 (14), p.4926-4932, 1973.

28. JIANG, L.; HE, L.; FOUNTOULAKIS, M. Journal of Chromatography A, v.1023, p.317-320, 2004.

29. ZELLNER, M.; WINKLER, W.; HAYDEN, H.; DIESTINGER, M.; ELIASEN, M.; GESSLBAUER, B.; MILLER, I.; CHANG, M.; KUNGL, A.; ROTH, E.; OEHLER, R. Electrophoresis, v.26, p.2481-2489, 2005.

30. OSS, C. J. V. Journal of Protein Chemistry, v.8 (5), p.661-668, 1989.

31. MONSIGNY, M.; SENE, C.; OBRENOVITCH, A.; ROCHE, A. C.; DELMOTTE, F.; BOSCHETTI, E. European journal of biochemistry, v.98, p.39-45, 1979.

32. MONSIGNY, M.; ROCHE, A. C.; SENE, C.; MAGET-DANA, R.; DELMOTTE, F. European journal of biochemistry, v.104, p.147-153, 1980.

33. HELENIUS, A.; SIMONS, K. Biochimica et Biophysica Acta, v.415, p.29-79, 1975.

34. MICHAEL, F.; JURANVILLE, J. F.; MANNEBERG, M. Journal of Biochemical and Biophysical Methods, v.24, p.256-274, 1992.

35. TAL, M.; SIBERSTEIN, A.; NUSSER, E. Journal of Biological Chemistry, v.260, p.9976-9980, 1985. 
36. CUTALO, J. M.; DETERDING, L. J.; TOMER, K. B. Journal of the American Society for Mass Spectrometry, v.15 (11), p.1545-1555, 2004.

37. LAI, C. C.; HER, G. R. Rapid Communication in Mass Spectrometry, v.14, p.2012-2018, 2000.

38. MARIANNE, T.; PERINI, J.; HOUVENAGHEL, M.; TRAMU, G.; LAMBLIN, G.; ROUSSEL, P. Carbohydrate Research, v.151, p.7-19, 1986.

39. WOODWARD, H. D.; RINGLER, N. J.; SELVAKUMAR, R.; SIMET, I. M.; BHAVANADAN, V. P.; DAVIDSON, E. A. Biochemistry, v.26, p.5315-5322, 1987.

40. SENAPATI, S.; DAS, S.; BATRA, S. K. Trends in Biochemical Sciences, v.35 (4), p.236-245, 2009.

41. SHARMA, P.; GHAVAMI, S.; STELMACK, G. L.; MCNEILL, K. D.; MUTAWE. M. M.; KLONISCH, T.; UNRUH, H.; HALAYKO, A. J. Journal of Cell Science, v.123, p.3061-3070, 2010.

42. RICHERT, S.; LUCHE, S.; CHEVALLET, M.; DORSSELAER, A. V.; WAGNER, E. L.; RABILLOUD, T. Proteomics, v.4, p.909-916, 2004.

43. CHEVAllet, M.; LUCHE, S.; DIEMER, H.; STRUB, J. M.; DORSSELAER, A. V.; RABILLOUD, T. Proteomics, v.8, p.4853-4861, 2008.

44. MOLLER, H. J.; POULSEN, J. H. Analytical Biochemistry, v.226, p.371-374, 1995.

45. GEISER, L.; DAYON, L.; VAEZZADEH, A. R.; HOCHSTRASSER, D. F. Methods in Molecular Biology, v.681, p.459-472, 2011.

46. STASYK, T.; HUBER, L. A. Proteomics, v.4, p.3704-3716, 2004. 
Capítulo 3

Caracterização da $\alpha$-DG por técnicas

imunoanalíticas 


\subsection{Introdução}

O termo blotting refere-se à tranferência de macromoléculas para membranas imobilizadoras, a fim de possibilitar uma detecção específica e sensível. ${ }^{1}$ Este método amplia as possibilidades de detecção de compostos separados eletroforeticamente porque as moléculas adsorvidas na superfície da membrana ficam livremente disponíveis para interação com ligantes macromoleculares específicos, como por exemplo antígenos, anticorpos, lectinas ou ácidos nucléicos. ${ }^{2}$

Os ensaios com proteínas ligadas a membranas geralmente são realizados imunologicamente com anticorpos. ${ }^{3}$ A transferência eletroforética de proteínas previamente separadas para uma membrana com subsequente imunodetecção foi introduzida por Towbin $e t$ $a l .{ }^{4}$ Este método posteriormente ficou conhecido como Western blotting (WB), termo aplicado até atualmente. ${ }^{1}$

A análise por WB combina a eficiência da eletroforese em gel com a especificidade dos imunoensaios, permitindo que proteínas individuais em misturas complexas sejam detectadas e analisadas. O imunoblotting foi desenvolvido por causa do desejo de examinar proteínas que eram inacessíveis a anticorpos quando presentes em géis de poliacrilamida. A seletividade e a especificidade do imunoblotting podem ser também utilizada em diagnósticos clínicos. ${ }^{3}$

\subsubsection{Anticorpos}

Para um químico que estuda proteínas, os anticorpos (Ab) são reagentes altamente específicos empregados para detectar e identificar proteínas alvo. Os Ab consistem de dois tipos de cadeias polipeptídicas unidas entre si por pontes dissulfeto, como ilustrado na Figura 3.1. A cadeia pesada possui MM em torno de $55 \mathrm{kDa}$ e a cadeia leve, aproximadamente 25 $\mathrm{kDa}$. Ambas cadeias pesadas e leves possuem uma região constante e uma variável. As regiões variáveis são localizadas na parte N-terminal e consistem de aproximadamente 100 
aminoácidos. São estas regiões que fazem contato com o antígeno. A região constante Cterminal da molécula é construída por um número limitado de sequências e serve para definir o subtipo de anticorpo. Os 5 isotipos de anticorpos humanos, IgM, IgD, IgG, IgA e IgE, são definidos por 5 diferentes tipos de cadeias pesadas, mu $(\mu)$, delta $(\delta)$, gama $(\gamma)$, alfa $(\alpha)$ e epsilon $(\varepsilon)$, respectivamente. Há dois tipos de cadeias leves, kappa ( $\kappa)$ e lambda $(\lambda)$, para todas as classes de imunoglobulinas. IgG, a imunoglobulina presente em maior concentração no soro, $\operatorname{IgD}$ e $\operatorname{IgE}$ são todas compostas de duas cadeias pesadas e duas cadeias leves. Estruturalmente, IgM é um pentâmero de moléculas semelhantes à IgG, enquanto que IgA é um dímero. 5

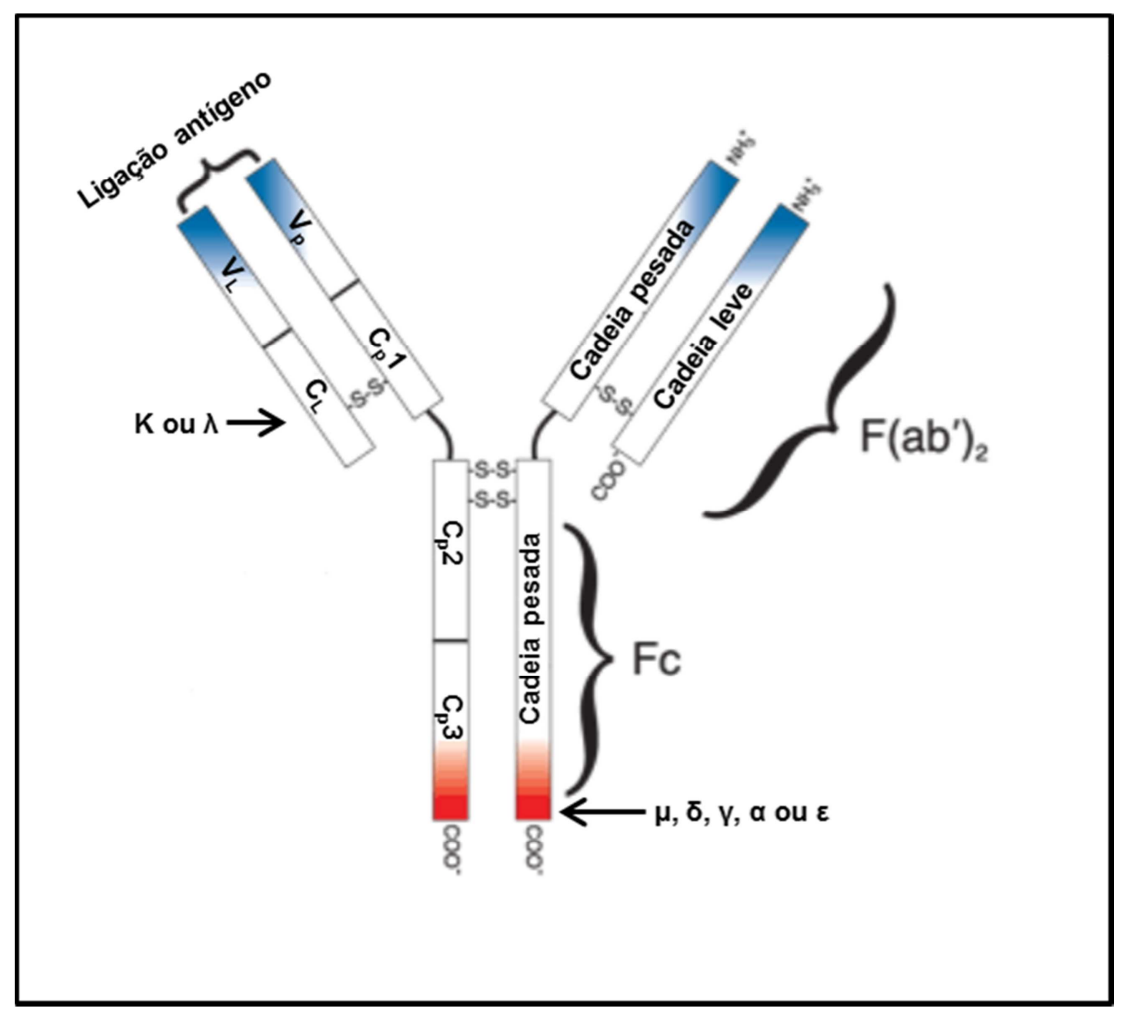

Figura 3.1 - Representação esquemática de uma molécula de anticorpo. ${ }^{6}$

\section{Anticorpos policlonais}

Há dois tipos de anticorpos usados como reagentes: monoclonal (mAb) e policlonal. Uma solução de anticorpo policlonal é uma mistura heterogênea de anticorpos que reconhecem inúmeros epitopos num único antígeno. A produção de anticorpos policlonais, com o objetivo de produzir um reagente de laboratório útil, requer a imunização de um animal com um antígeno extremamente puro. Anticorpos específicos podem ser produzidos por 
diferentes clones de linfócitos $\mathrm{B}$, que reagem com diferentes regiões na mesma molécula de antígeno. Esta é a resposta imunológica heterogênea normal a um antígeno, resultando na produção de anticorpos policlonais. ${ }^{5}$

\section{Anticorpos monoclonais}

Köhler e Milstein $^{7}$ desenvolveram métodos que permitiram o crescimento de populações de células clonais que secretam anticorpos com especificidades definidas. Essas células são chamadas de hibridomas. Os anticorpos isolados de um único clone são idênticos (monoclonais) e reagirão com um epitopo específico do antígeno o qual ele detecta. Estes hibridomas podem ser propagados in vitro, se multiplicam indefinidamente em cultura, e secretam continuamente anticorpos monoclonais com uma especificidade definida. Um grupo de anticorpos monoclonais pode ser produzido contra uma população de moléculas não purificadas e depois ser selecionado com base em suas propriedades antigênicas contra a molécula alvo. ${ }^{5}$

A despeito das muitas similaridades, cada anticorpo monoclonal específico para um epitopo é uma proteína única e apresenta seus próprios desafios para purificação. Isto porque MAbs diferem em estabilidade e afinidade, características que afetam o comportamento de MAbs individuais em aplicações analíticas e em purificações. A diversidade de aminoácidos encontrados na região variável resulta num amplo intervalo de pI para estas moléculas, por isso cada MAb terá propriedades diferentes. ${ }^{5}$

\subsubsection{Princípios da técnica de WB}

Um experimento típico de WB consiste de 6 etapas inter-relacionadas: ${ }^{3}$

1) As proteínas são primeiramente separadas por eletroforese num gel de poliacrilamida. ${ }^{3}$

2) As proteínas do gel são então transferidas para uma membrana, onde ficam imobilizadas. ${ }^{3}$ Proteínas são grandes demais para eluírem quantitativamente do gel de SDSPAGE por difusão ou por forças capilares, por isso são transferidas eletroforeticamente. ${ }^{1}$ Esta 
transferência produz uma réplica fiel do gel na membrana, retendo a resolução total do gel. ${ }^{3}$ Atualmente existem dois tipos principais de equipamentos para electroblotting: arranjos de placas de eletrodos, para as chamadas transferências semi-secas (semidry) (Figura 3.2 A e B), e tanques de tampão com eletrodos colocados apropriadamente (Figura 3.2 C e D). Estes equipamentos são disponíveis para acomodar géis de todos os tamanhos. ${ }^{3}$
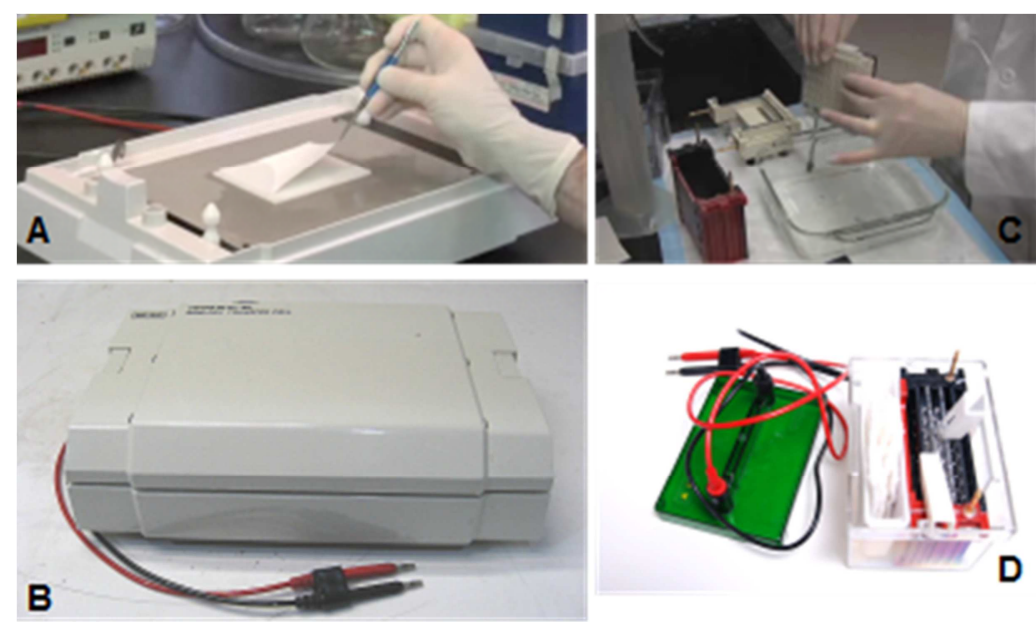

Figura 3.2 - Equipamentos utilizados para electroblotting. A e B: arranjo de placas de eletrodos para transferências semi-secas. ${ }^{8,9} \mathbf{C}$ e $\mathbf{D}$ : tanque de tampão. ${ }^{10,11}$

Nas tranferências realizadas em tanques, o gel e a membrana são fixados em suportes entre filtros de papel e esponjas, e suspensos no tanque cheio de tampão. Grandes volumes de tampão no tanque ajudam a dissipar o calor gerado durante a tranferência. Os tanques são recomendados para trabalhos de rotina. Neles, a transferência ocorre de uma maneira mais eficiente do que em sistemas semi-secos. ${ }^{2,3}$

Nas cubas semi-secas, é feito um "sanduíche" disposto horizontalmente com o gel e a membrana, que é empilhado entre papéis de filtro molhados com tampão, e esse conjunto é colocado em contato direto com as placas dos eletrodos. ${ }^{3} \mathrm{O}$ termo semi-seco refere-se à quantidade limitada de tampão que é confinado na pilha de papéis de filtro. ${ }^{3}$ Umas das desvantagens deste método é que, em condições semi-secas, algumas proteínas pequenas são perdidas por sua saída da membrana e, devido à baixa capacidade de tampão nesta cuba, o tempo de corrida deve ser limitado. ${ }^{2,3}$ Por isso, algumas proteínas de alta MM também são tranferidas ineficientemente. Ainda assim, por essas cubas semi-secas requererem menor quantidade de tampão e serem de utilização mais fácil, elas são escolhidas por laboratórios que realizam um grande número de blots por período. ${ }^{2,3}$ 
A membrana suporte mais utilizada para WB é a de nitrocelulose. A ligação das proteínas à membrana de nitrocelulose, que ocorre por forças hidrofóbicas, é instantânea, praticamente irreversível, e quantitativa para uma ampla faixa de concentração de proteínas (até $80-100 \mu \mathrm{g} / \mathrm{cm}^{2}$ ). ${ }^{3}$ As membranas de nitrocelulose ligam proteínas pequenas mais eficientemente, e podem ser usadas para métodos preparativos, pois as proteínas podem ser posteriormente eluídas dela. ${ }^{2}$

Membranas de difluoreto de polivinilideno (PVDF) também ligam proteínas fortemente $\left(170-200 \mu \mathrm{g} / \mathrm{cm}^{2}\right)$ e são estáveis nos agentes químicos usados para sequenciamento de proteínas. Desta forma, podem ser inseridas diretamente em sequenciadores de fase sólida. Membranas de PVDF tendo base de teflon possuem uma alta capacidade de ligação e uma grande estabilidade mecânica., ${ }^{2,3}$

Infelizmente uma membrana de blotting que ligue 100\% das moléculas ainda não existe. Por isso é necessário otimizar a eletrotransferência para obter tranferências as mais uniformes e quantitativa possíveis. ${ }^{2}$

3) Em seguida, os sítios de ligação que estão vazios na membrana são saturados para prevenir ligações inespecíficas de anticorpos. ${ }^{3}$ Esses sítios de ligação da membrana que estão livres podem ser bloqueados com uma mistura de proteína que não interfira com o teste subsequente com um anticorpo. O bloqueio efetivo da membrana de nitrocelulose pode ser conseguido com incubação em leite desnatado diluído ou em solução de albumina de soro bovino (bovine serum albumin - BSA) por 30 - $60 \mathrm{~min}$, seguido por lavagens com 0,05\% Tween 20. Falhas nesta etapa de bloqueio resultam em backgrounds (sinal de fundo) elevado, comprometendo o resultado final do experimento.,

4) A membrana é então testada para a presença de proteínas de interesse, com o uso de anticorpos primários específicos. Anticorpos com altas especificidade e pureza são as melhores escolhas para anticorpos primários e secundários. Tween 20 e uma porcentagem de BSA devem ser incluídos nos tampões de diluição para minimizar a adsorção inespecíficas destes probes às membranas. ${ }^{3}$

5) Anticorpos secundários, específicos contra os anticorpos primários utilizados, são usados para marcar os anticorpos primários. Os anticorpos secundários são comercializados já 
conjugados a grupos detectáveis (sondas), como enzimas ou isótopos radioativos. A sensibilidade final de um blot é determinado por essas sondas. ${ }^{3}$

Substratos enzimáticos cromogênicos para aplicações em blotting permitem que bandas de proteínas sejam diretamente visualizadas. Eles são convertidos em produtos insolúveis e coloridos que precipitam e se ligam a membranas nos sítios das enzimas. Dependendo da enzima e do substrato, a sensibilidade varia entre dezenas a centenas de picogramas de proteína. Fosfatase alcalina (alkaline phosphatase - AP) é o marcador de escolha para detecção cromogênica de immunoblotts, gerando resultados com sensibilidade de 10-100 pg para a proteína de interesse. ${ }^{3}$

Substratos quimioluminescentes (enhanced chemiluminescence - ECL) são pelo menos 10 vezes mais sensíveis do que os cromogênicos. A desvantagem do seu uso é que a detecção requer o uso de filmes fotográficos ou instrumentação específica (fotodocumentadores), em comparação à revelação dos substratos cromogênicos como AP, por exemplo, que podem ser diretamente visualizados no blot assim que o substrato é convertido a produto pela enzima. Luminol é um substrato apropriado para a horseradish peroxidase (HRP), e certos compostos dioxetanas são adequados para uso com AP. O sinal do luminol diminui com o tempo, por isso a exposição da membrana deve ser realizada imediatamente após a adição do substrato ao blot, enquanto que as dioxetanas produzem um sinal mais duradouro. ${ }^{1,3}$

6) Finalmente, as bandas de proteínas marcadas são visualizadas pelos meios adequados, em condições apropriadas que dependem do anticorpo secundário aplicado. ${ }^{3}$ 


\subsection{Objetivos}

O uso do método de WB para análise de proteínas de músculos estriados teve como objetivos:

- certificar a presença da $\alpha-D G$ e da $\beta$-DG nas frações de proteínas extraídas e purificadas pela metodologia desenvolvida, visto que estas proteínas não foram detectadas nos géis de 2-DE coloridos por Coomassie blue ou nitrato de prata.

- verificar se estas mesmas proteínas provenientes de camundongos LARGE também possuíam afinidade pela WGA succinilada, mesmo com diferenças de glicosilação em relação aos animais controle.

- estudar a seletividade de cada anticorpo primário anti $\alpha$-DG disponível, para detecção de diferentes epitopos desta glicoproteína, e correlacionar os resultados obtidos com as diferenças de glicosilação encontradas entre camundongos controle e LARGE. 


\subsection{Experimental}

\subsubsection{Extração, processamento e purificação de amostras musculares de modelos murinos}

As amostras de camundongos usadas nos experimentos de WB foram extraídas e homogeneizadas seguindo os mesmos procedimentos das amostras de 2-DE. Os músculos de coelho foram adquiridos em estabelecimento de venda de carnes para uso culinário, e foram utilizados a fim de se comparar os resultados entre diferentes espécies. Após a homogeneização dos tecidos e separação entre sobrenadante (contendo as proteínas) e precipitado, as proteínas de camundongos controle, assim como as de camundongos LARGE e de coelho foram purificadas por cromatografia de lectina, mais precisamente pela WGA succinilada ligada a agarose, também escolhida para o pré-fracionamento das amostras de 2DE. Todas as etapas de purificação por WGA foram semelhantes às descritas para as amostras de 2-DE. Para as análises por WB, entretanto, não foi necessário efetuar a diálise e liofilização das proteínas já purificadas.

\subsubsection{SDS-PAGE e blotting}

Após o fracionamento das proteínas por WGA, cada alíquota de $30 \mu \mathrm{L}$ das amostras foram misturadas com $10 \mu \mathrm{L}$ de tampão de amostra para SDS-PAGE, concentrado $4 \times$, e preparado com os reagentes listados na Tabela 3.1 a seguir. Após isso, as soluções contendo as proteínas e o tampão de amostra foram aquecidas a $100{ }^{\circ} \mathrm{C}$ por 5 minutos, para garantir uma completa desnaturação das proteínas. Antes da adição das alíquotas nas canaletas do gel de SDS-PAGE, essas amostras foram resfriadas a $4{ }^{\circ} \mathrm{C}$. 
Tabela 3.1- Composição do tampão de amostra para SDS-PAGE, concentrado 4x.

\begin{tabular}{lc}
\hline \multicolumn{1}{c}{ Reagente } & Concentração final \\
\hline Tris-HCl (pH 6,8) & $200,0 \mathrm{mmol} \mathrm{L}^{-1}$ \\
SDS & $4 \%(\mathrm{~m} / \mathrm{v})$ \\
Glicerol & $40 \%(\mathrm{v} / \mathrm{v})$ \\
DTT & $200,0 \mathrm{mmol} \mathrm{L}^{-1}$ \\
Azul de bromofenol & $0,02 \%(\mathrm{~m} / \mathrm{v})$ \\
\hline
\end{tabular}

Os géis de resolução utilizados para separação das amostras foram preparados com espessura de $1 \mathrm{~mm}$, numa concentração de poliacrilamida de $8 \%$. Já os géis de empilhamento foram polimerizados numa concentração de poliacrilamida de 5\%. As condições de eletroforese utilizadas para separação foram: aplicação de $150 \mathrm{~V}$ constante, do ínicio ao fim da corrida.

Imediatamente após a separação, as proteínas foram transferidas do gel para membranas de ntirocelulose em tanques, com a aplicação de $100 \mathrm{~V}$ constante, durante $1 \mathrm{~h}$. Para a verificação da efetividade da transferência, as membranas foram coradas com Ponceau S.

\subsubsection{Imunodetecção}

Todos os experimentos de imunodetecção seguiram rigorosamente as etapas detalhadas a seguir, sendo que apenas as concentrações dos anticorpos primários e secundários foram modificadas para cada teste, quando necessário, pois cada anticorpo possui uma concentração ótima de trabalho.

Etapas de blotting:

1. bloqueio da membrana em leite desnatado $3 \%(\mathrm{~m} / \mathrm{v})$, diluído em tampão (Tweenphosphate buffered saline) T-PBS, preparado conforme a Tabela 3.2. Duração: $2 \mathrm{~h}$.

2. lavagem da membrana com T-PBS puro, por $10 \mathrm{~min}$.

3. adição do anticorpo primário diluído em T-PBS contendo 3\% (m/v) BSA. Duração: no mínimo $1 \mathrm{~h}$.

4. lavagem da membrana com T-PBS puro, por $10 \mathrm{~min}$. 
5. lavagem com leite desnatado 3\% (m/v), diluído em tampão T-PBS, por 10 min. Esta etapa foi feita 2 vezes.

6. lavagem da membrana com T-PBS puro, por $10 \mathrm{~min}$.

7. incubação da membrana com o anticorpo secundário conjugado à HRP, diluído em TPBS contendo 3\% (m/v) BSA. Duração: 1 h

8. duas lavagens com leite desnatado $3 \%(\mathrm{~m} / \mathrm{v})$, diluído em tampão T-PBS, por 15 min cada.

9. três lavagens com T-PBS puro, por 10 min cada.

10. revelação por ECL (Amersham)

Tabela 3.2- Composição do tampão T-PBS, pH 7,3.

\begin{tabular}{lc}
\hline Reagente & Concentração final \\
\hline $\mathrm{KH}_{2} \mathrm{PO}_{4}$ & $1,4 \mathrm{mmol} \mathrm{L}^{-1}$ \\
$\mathrm{Na}_{2} \mathrm{HPO}_{4}$ & $8 \mathrm{mmol} \mathrm{L}^{-1}$ \\
$\mathrm{NaCl}$ & $140 \mathrm{mmol} \mathrm{L}^{-1}$ \\
$\mathrm{KCl}$ & $2,7 \mathrm{mmol} \mathrm{L}^{-1}$ \\
\hline
\end{tabular}

\subsubsection{Laminin overlay}

Para os testes de laminin overlay, a membrana contendo as proteínas passou por uma série de etapas, descritas a seguir:

1. bloqueio da membrana por $2 \mathrm{~h}$, em $5 \%(\mathrm{~m} / \mathrm{v})$ de leite desnatado diluído em tampão de ligação da laminina (LBB). Este tampão foi preparado com os reagentes organizados na Tabela 3.3.

2. lavagem da membrana com LBB puro, por 10 min.

3. incubação da membrana com $16 \mathrm{mmol} \mathrm{L}^{-1}$ de laminina dissolvida em LBB, overnight.

4. lavagem do excesso de laminina com $5 \%(\mathrm{~m} / \mathrm{v})$ de leite desnatado diluído em LBB, por $10 \mathrm{~min}$. Esta etapa foi repetida num total de 3 vezes.

5. lavagem com LBB puro, por $10 \mathrm{~min}$. 
6. incubação da membrana com anticorpo anti-laminina diluído em LBB mais $3 \%(\mathrm{~m} / \mathrm{v})$ de BSA, durante $1 \mathrm{~h}$.

7. lavagem da membrana com LBB puro, por $10 \mathrm{~min}$.

8. lavagem com leite desnatado $3 \%(\mathrm{~m} / \mathrm{v})$, diluído em tampão LBB, por $10 \mathrm{~min}$. Esta etapa foi feita 2 vezes.

9. lavagem da membrana com LBB puro, por $10 \mathrm{~min}$.

10. incubação da membrana com o anticorpo secundário conjugado à HRP, diluído em LBB contendo 3\% (m/v) BSA. Duração: $1 \mathrm{~h}$

11. duas lavagens com leite desnatado 3\% (m/v), diluído em tampão LBB, por 15 min cada.

12. três lavagens com LBB puro, por 10 min cada.

13. revelação por ECL (Amersham)

Tabela 3.3- Composição do tampão LBB, pH 7,6.

\begin{tabular}{lc}
\hline \multicolumn{1}{c}{ Reagente } & Concentração final \\
\hline trietanolamina & $10 \mathrm{mmol} \mathrm{L}^{-1}$ \\
$\mathrm{MgCl}_{2}$ & $1 \mathrm{mmol} \mathrm{L}^{-1}$ \\
$\mathrm{CaCl}_{2}$ & $1 \mathrm{mmol} \mathrm{L}^{-1}$ \\
$\mathrm{NaCl}$ & $140 \mathrm{ol} \mathrm{L}^{-1}$ \\
\hline
\end{tabular}

\subsubsection{Cromatografia de imunoafinidade}

A proteína L foi imobilizada na superfície de sílica diol Nucleosil 4000-7 (7 ㅆm, 4000 $\AA$ ) seguindo os procedimentos descritos por Svoboda et al. $^{12}$, e reproduzidos a seguir.

Uma massa de $125 \mathrm{mg}$ de sílica (forma diol) foi suspensa em $5 \mathrm{~mL}$ de ácido acético/água $(9: 1, \mathrm{v} / \mathrm{v})$, e tendo $125 \mathrm{mg}$ de periodato de sódio adicionado à mesma sílica para oxidar os dióis a aldeídos; esta mistura foi agitada por $3 \mathrm{~h}$ à temperatura ambiente. Em seguida, a sílica foi lavada com excesso de água, etanol e éter, e seca sob vácuo. A sílica modificada foi suspensa em $5 \mathrm{~mL}$ de tampão fosfato de sódio $0,1 \mathrm{~mol} \mathrm{~L}^{-1}(\mathrm{pH} \mathrm{7,5)} \mathrm{contendo}$ 0,25 mol L ${ }^{-1}$ de cloreto de sódio. Logo após, 0,5 mg de proteína L dissolvida em $100 \mu \mathrm{L}$ de 
água foi adicionada à sílica, seguido pela adição de $0,35 \mathrm{mg}$ de cianoborohidreto de sódio. A mistura foi agitada a $4{ }^{\circ} \mathrm{C}$ por $72 \mathrm{~h}$. Após isso, $2,5 \mathrm{mg}$ de borohidreto de sódio foi adicionado aos poucos, durante $30 \mathrm{~min}$, a fim de reduzir os grupos aldeídos que não reagiram a tióis. Terminada esta etapa, a suspensão foi agitada por $1 \mathrm{~h} \mathrm{a} 4{ }^{\circ} \mathrm{C}$. A sílica ligada à proteína foi lavada 4 vezes com tampão PBS $0,1 \mathrm{~mol} \mathrm{~L}^{-1}, \mathrm{pH} 7,4$, contendo $0,15 \mathrm{~mol} \mathrm{~L}^{-1}$ de cloreto de sódio e $0,02 \%$ de azida sódica.

O preenchimento da microcoluna com as partículas se deu num instrumento de cromatografia líquida rápida de proteínas (FPLC) da Amershan Biosciences (Piscattaway, NJ, EUA), num fluxo de $100 \mu \mathrm{L} \mathrm{min}{ }^{-1}$ por $30 \mathrm{~min}$. A coluna tinha dimensões de $5 \mathrm{~cm}$ de comprimento e 0,5 $\mathrm{mm}$ d.i.. A coluna foi fechada com duas fritas de aço inoxidável de $0,5 \mu \mathrm{m}$ de tamanho de malha.

Os experimentos de cromatografia de imunoafinidade foram realizados num sistema ÄKTApurifier 10 equipado com um detector de UV fixado em $280 \mathrm{~nm}$. As frações eluídas da coluna foram quantificadas, e as que mostraram a presença de proteínas foram digeridas por tripsina e analisadas por cromatografia líquida capilar (cLC) acoplada online num instrumento de ESI-ICR-FT. Os instrumentos utilizados foram um nanoLC Ultimate 3000 LC system (Dionex, Sunnyvale, CA, EUA), com coluna de fase reversa (5 $\mu$ m d.p.; 0,075 mm x $15 \mathrm{~cm}$ ) preparada in-house com sílica C12 Jupiter Proteo (Phenomenex, Torrance, CA, EUA), acoplado a um espectrômetro de massas LTQ ICR-FT (Thermo Finnigan, San Jose, CA, EUA)

Os peptídeos foram separados aplicando-se um gradiente linear de 3 a 55\% de fase B (3:97:0,1 água/ACN/ácido fórmico) durante $45 \mathrm{~min}$, seguido por 55 a $80 \%$ de ACN por 10 min. A fase A foi preparada com 97:3:0,1 água/ACN/ácido fórmico. O eluente da coluna foi ionizado por electrospray utilizando uma diferença de potencial de $1,8 \mathrm{kV}$. Os espectros de massas foram adquiridos no intervalo de 200 a $2200 \mathrm{~m} / \mathrm{z}$, seguido pela aquisição dos espectros de MS/MS.

Os experimentos de cromatografia de imunoafinidade foram realizados sob supervisão do prof. Dr. Milos Novotny, no Departamento de Química da Universidade de Indiana (Bloomington, IN, EUA). 


\subsection{Resultados e discussão}

Após a purificação de todas as amostras por WGA, alíquotas de mesmo volume foram separadas para testes de controle interno positivo. As proteínas escolhidas para controle foram a $\beta$-actina (42 kDa) e a $\beta$-DG (43 kDa, glicosilada). Os anticorpos primários utilizados foram específicos para proteínas extraídas de camundongo. A Figura 3.3 apresenta a fotografia de uma membrana de nitrocelulose incubada com anti $\beta$-actina.

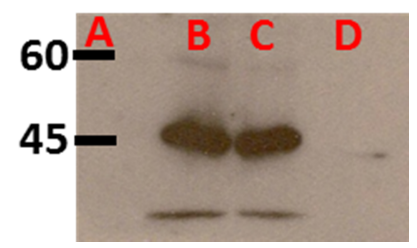

Figura 3.3 - Experimento de controle interno positivo (WB), com utilização de anti $\beta$-actina, específico para proteína de camundongos. A: padrões de massa molecular. B: quadríceps de camundongo LARGE. C: quadríceps de camundongo controle. D: quadríceps + gastrocnêmio de coelho controle. Proteínas separadas por SDS-PAGE 8\% e transferidas para membrana de nitrocelulose.

Conforme esperado, apenas as bandas de $\beta$-actina das amostras de camundongos foram detectadas nesta membrana (canaletas B e C da Figura 3.3), pois o anticorpo escolhido não reconhecia proteína de coelho (canaleta $D$ da Figura 3.3). A proteína $\beta$-actina não é expressa em concentrações diferentes quando o animal é afetado pela mutação no gene LARGE. Por isso, esta proteína é uma boa escolha para uso como controle interno positivo, neste caso. Com a quantificação da $\beta$-actina pelos sinais do WB, foi determinada a razão de volume de cada amostra a ser inserida nas canaletas, para os experimentos com anti $\alpha$-DG.

Os testes com anti $\beta$-DG tiveram três finalidades: i) confirmar os resultados de controle interno positivo obtidos com a $\beta$-actina, aumentando assim a confiabilidade dos resultados seguintes de comparação entre animais LARGE e controle contra a $\alpha$-DG; ii) mostrar que a $\beta$-DG também é purificada, juntamente com a $\alpha$-DG, pela coluna de WGA. Isto é, a $\beta$-DG mostra-se presente na fração eluída especificamente com N-acetil-D-glucosamina; e iii) comprovar que a $\beta$-DG não sofre alterações estruturais ou de concentração nos animais LARGE.

Uma das membranas incubadas com anti $\beta$-DG está ilustrada na Figura 3.4. Devido ao fato de o anticorpo empregado neste teste ser também específico para amostras de 
camundongo, a $\beta$-DG de coelho não foi detectada na membrana (canaleta A, Figura 3.4). Não foram encontradas diferenças significativas de mobilidade ou de concentração desta proteína entre camundongos LARGE e controle, o que leva à conclusão de que mutações no gene LARGE não interferiram na expressão da $\beta$-DG presente nos tecidos musculares analisados.

A presença de sinais específicos para a $\beta$-DG na Figura 3.4 é uma confirmação de que esta proteína também pode ser purificada, juntamente com a $\alpha$-DG, por WGA. Como pode ser visto na representação da Figura 3.5, a $\beta$-DG possui um sítio de N-glicosilação. No entanto, não é possível afirmar que esta proteína se liga especificamente à WGA pelo resíduo de Nglicana presente na molécula, ou se sua eluição juntamente com a $\alpha$-DG ocorre devido a interações entre as duas proteínas. Isto porque a estrutura do resíduo de açúcar presente na $\beta$ DG ainda não é conhecido.

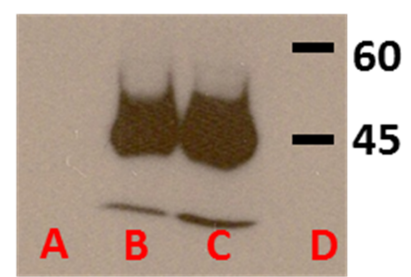

Figura 3.4 - WB realizado com anti $\beta$-DG específico para proteína de camundongos. A: músculo de coelho controle (quadríceps e gastrocnêmio). B: quadríceps de camundongo LARGE. C: quadríceps de camundongo controle. D: padrões de massa molecular. Proteínas separadas por SDS-PAGE 8\% e transferidas para membrana de nitrocelulose.

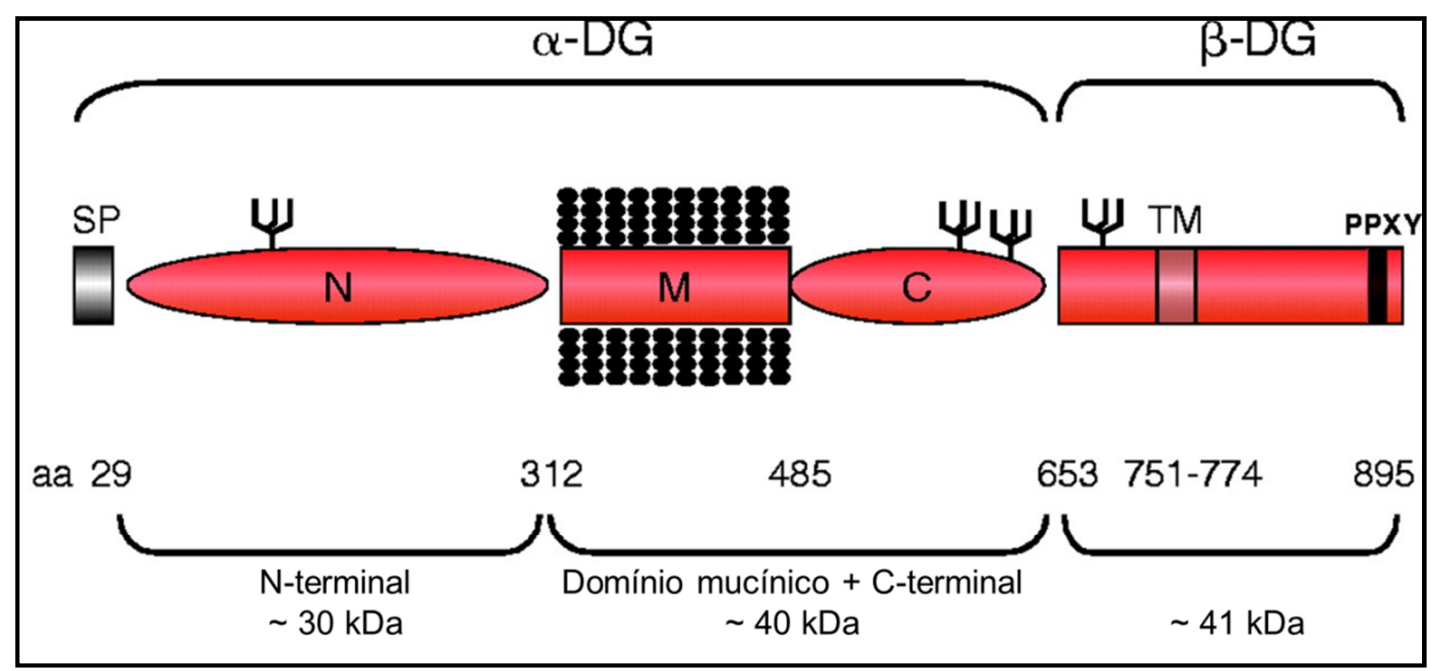

Figura 3.5 - Organização do domínio distroglicana. A quebra do domínio ocorre entre Arg 312 e Gln 313. Círculos indicam acúcares O-ligados. Ramos indicam açucares N-ligados. SP, peptídeo sinal; TM, domínio transmembrana; PPXY, sítio de ligação à distrofina. MM indicadas referem-se aos peptídeos sem glicosilação. ${ }^{13}$ 
Com os resultados dos controles internos já conhecidos, a próxima etapa foi comparar as amostras de tecidos LARGE e controle, com o uso de anticorpos específicos para a $\alpha$-DG glicosilada. Dois anticorpos monoclonais diferentes foram empregados nestas análises de WB: VIA4-1 (Figura 3.6) e IIH6 (Figura 3.7). Embora estes dois anticorpos reconheçam epitopos glicosilados da $\alpha$-DG, cada um é específico para uma região da glicoproteína madura. Dados da literatura mostram que o anticorpo IIH6 se liga à mesma região de ligação da $\alpha$-DG à laminina, e que sua interação com esta glicoproteína bloqueia seu sítio de ligação com a laminina, impedindo sua interação concomitante com o anticorpo. O mesmo não é observado com o anticorpo VIA4-1. ${ }^{14}$

Na Figura 3.6 foi possível observar algumas bandas relativas a interações inespecíficas do anticorpo secundário com outras proteínas presentes nas amostras, que não coincidem com a MM esperada da $\alpha$-DG nos tecidos empregados (156 kDa, bandas marcadas com asterisco). Porém, um fato que chamou atenção foi a detecção de uma banda alargada de MM menor que a da $\alpha$-DG, presente somente nas amostras de camundongo LARGE (Figura 3.6 C e F). Estas bandas também foram marcadas com asterisco, assim como as da $\alpha$-DG com MM esperada. Embora não descrito na literatura, aparentemente este anticorpo também detectou isoformas hipoglicosiladas presentes nas amostras LARGE. Geralmente, as glicoproteínas separadas em géis de poliacrilamida apresentam bandas largas, devido às várias isoformas glicosiladas que não são totalmente resolvidas no gel. Por isso, acredita-se que as bandas detectadas em torno de $120 \mathrm{kDa}$ se tratam de isoformas da $\alpha$-DG. Por outro lado, na Figura 3.7 foram observadas bandas características de glicoproteínas somente nas amostras controle (Figura $3.7 \mathrm{C} \mathrm{e} \mathrm{F}$ ), com MM de aproximadamente $156 \mathrm{kDa}$. Isto se deve provavelmente pelo fato de o anticorpo IIH6 se ligar somente a isoformas da $\alpha$-DG que sejam capazes também de se ligar à laminina. Em outras palavras, o anticorpo IIH6 detecta somente as isoformas funcionais da $\alpha$-DG. ${ }^{14}$

A $\alpha$-DG funciona como um receptor para o domínio da matriz extracelular laminina $\mathrm{G}$. Este domínio contém os ligantes laminina e agrina, em tecidos musculares e também no cérebro. O sucesso da ligação da $\alpha$-DG a esses ligantes depende estritamente das modificações pós-traducionais nela presentes, isto é, dos resíduos de oligossacarídeos. Entretanto, as estruturas desses resíduos específicos para a interação com a $\alpha$-DG ainda não são conhecidas. ${ }^{15}$ Portanto, os defeitos de glicosilação da $\alpha$-DG ocorridos em animais com mutações no gene LARGE impedem a interação entre esses ligantes, causando assim os 
sintomas associados à CMD1D. O experimento de laminin overlay mostra na prática o efeito da mutação do gene LARGE na interação entre $\alpha$-DG e laminina.

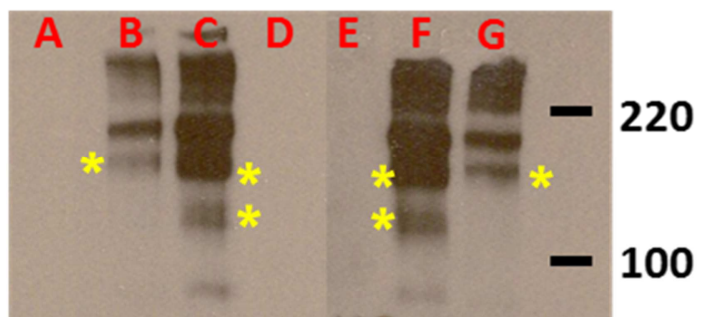

Figura 3.6 - WB realizado com anti $\alpha$-DG, VIA4-1. A: músculo de coelho controle (quadríceps e gastrocnêmio). B: quadríceps de camundongo controle. C: quadríceps de camundongo LARGE. D: músculo de coelho controle (quadríceps e gastrocnêmio). E: padrões de massa molecular. F: gastrocnêmio de camundongo LARGE. G: gastrocêmio de camundongo controle. Proteínas separadas por SDS-PAGE 8\% e transferidas para membrana de nitrocelulose. As bandas marcadas com asterisco são possivelmente da $\alpha$-DG.

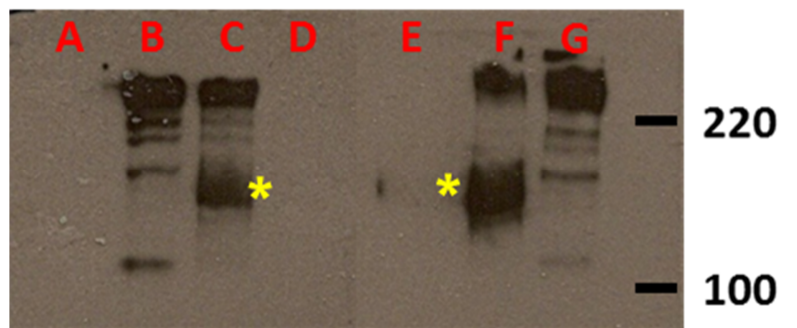

Figura 3.7 - WB realizado com anti- $\alpha$-DG, IIH6. A: padrões de massa molecular. B: quadríceps de camundongo LARGE. C: quadríceps de camundongo controle. D e E: músculo de coelho controle (quadríceps e gastrocnêmio). F: gastrocnêmio de camundongo controle. G: gastrocêmio de camundongo LARGE. Proteínas separadas por SDS-PAGE 8\% e transferidas para membrana de nitrocelulose. As bandas marcadas com asterisco são possivelmente da $\alpha$-DG.

As etapas de separação e transferência das proteínas para ensaio de laminin overlay foram semelhantes às de WB usuais. Somente a primeira etapa de incubação da membrana é que foi modificada. Ao invés de utilizar um anticorpo primário que reconhecesse uma proteína (extraída do tecido muscular) já imobilizada na membrana, a membrana foi primeiramente incubada com uma solução contendo laminina. Esta proteína, por sua vez, se ligaria especificamente a qualquer proteína que fosse sua receptora e estivesse imobilizada na membrana. A detecção das bandas contendo estes receptores de laminina foi feita com anticorpo anti laminina. Dessa forma, foi possível visualizar a existência de proteínas que se ligam a laminina presentes na amostra, no caso, a $\alpha$-DG. Este experimento foi realizado com as mesmas amostras anteriormente testadas com os anticorpos VIA4-1 e IIH6. Os resultados estão apresentados na Figura 3.8. As bandas às quais houve interação com a laminina estão 
localizadas somente nas canaletas com amostras de coelho (Figura 3.8 A e E) e de camundongo controle, tanto em músculo quadríceps como gastrocnêmio (Figura 3.8 B e F). A ligação da laminina nas amostras de camundongo ocorreu num intervalo de MM mais ampla do que nas de coelho, provavelmente devido a diferenças estruturais nas isoformas de $\alpha$-DG funcionais existente nas duas espécies estudadas. As proteínas de camundongos detectadas por IIH6 foram localizadas na mesma região de MM das visualizadas por laminin overlay, o que reforça ainda mais as informações obtidas em ambos os testes, e comprova a identidade do receptor da laminina presente nestas amostras.

Estes dados mostram a importância das modificações pós-traducionais na manutenção funcional de proteínas. No caso da $\alpha$-DG, a mutação das estruturas dos oligossacarídeos nela ligados resulta na ausência de ligação entre domínios protéicos, resultando em diversos sintomas indesejados para o ser vivo.

Todos os experimentos de imunodetecção feitos com proteínas separadas por eletroforese 1-D foram também repetidos com as mesmas amostras separadas por 2-DE, porém não foi possível detectar a $\alpha$ - ou a $\beta$-DG. Existem alguns trabalhos publicados que mostram resultados satisfatórios de imunoblotting após separação por 2-DE. Entretanto, igualmente como neste caso, frequentemente é observado que alguns anticorpos não reconhecem a proteína após todo o processo de preparo de amostra e separação que é efetuado em 2-DE. A causa desta observação ainda não foi explicada, porém existe uma hipótese de que a focalização da proteína no seu pI ou a presença de grande quantidade de uréia no sistema cause uma desnaturação muito maior da proteína, impedindo o reconhecimento antígeno-anticorpo. ${ }^{1}$

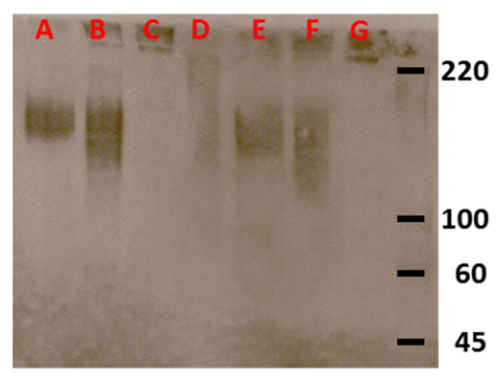

Figura 3.8 - Laminin overlay mostrando ausência de ligação de laminina nas amostras LARGE. A: músculo de coelho controle (quadríceps e gastrocnêmio). B: quadríceps de camundongo controle. C: quadríceps de camundongo LARGE. D: padrões de massa molecular. E: músculo de coelho controle (quadríceps e gastrocnêmio). F: gastrocnêmio de camundongo controle. G: gastrocêmio de camundongo LARGE. Proteínas separadas por SDS-PAGE 8\% e transferidas para membrana de nitrocelulose. 
Tendo em vista a alta especificidade da interação antígeno-anticorpo mostrada nas análises de WB apresentadas, buscou-se aliar esta característica a um método de separação, no caso a micro LC, para o desenvolvimento de uma coluna que pudesse reter especificamente a $\alpha$-DG, tornando possível uma futura comparação estrutural entre isoformas provenientes de diferentes animais, doentes ou não.

O anticorpo escolhido para este experimento foi o sobrenadante de hibridoma sx/3/50/25, gentilmente doado pelo Prof. Dr. Andrea Brancaccio (Istituto di Chimica del Riconoscimento Molecolare c/o Istituto di Biochimica e Biochimica Clinica, Università Cattolica del Sacro Cuore, Roma, Itália), para a fabricação de uma coluna de imunoafinidade. Segundo dados publicados na literatura, ${ }^{16}$ os anticorpos presentes neste sobrenadante reconhecem $\alpha$-DG parcialmente glicosiladas, porém, os mesmos nunca foram testados contra $\alpha$-DG isolada de camundongos LARGE. A escolha deste anticorpo para o teste levou em consideração sua capacidade de reconhecer o esqueleto polipeptídico da glicoproteína, mesmo que este não possuísse os resíduos de açúcares da molécula madura. A Figura 3.9 ilustra a membrana de nitrocelulose testada contra este sobrenadante de hibridoma sx/3/50/25. Como esperado, o anticorpo foi capaz de reconhecer bandas tanto em amostras de animais LARGE (Figura 3.9 C e G) como de controle (Figura 3.9 B e F). Após a obtenção destes resultados, foi iniciado o experimento de cromatografia de imunoafinidade.

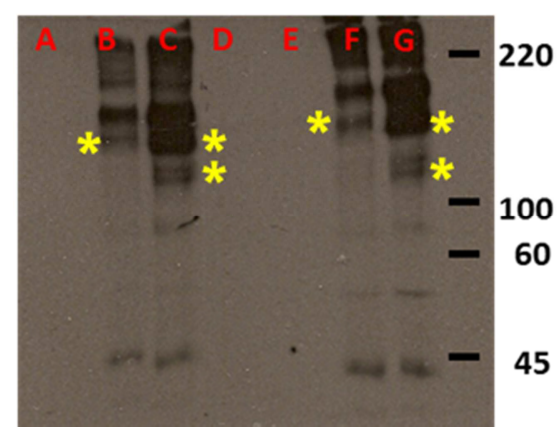

Figura 3.9 - WB realizado com o sobrenadante de hibridoma sx/3/50/25 ${ }^{[13]}$ (IgG anti $\alpha$-DG), A: músculo de coelho controle (quadríceps e gastrocnêmio). B: quadríceps de camundongo controle. C: quadríceps de camundongo LARGE. D: padrões de massa molecular. E: músculo de coelho controle (quadríceps e gastrocnêmio). F: gastrocnêmio de camundongo controle. G: gastrocêmio de camundongo LARGE. Proteínas separadas por SDS-PAGE $8 \%$ e transferidas para membrana de nitrocelulose. As bandas marcadas com asterisco são da $\alpha$-DG.

Basicamente, o experimento consistiu na ligação não covalente de proteina $\mathrm{L}$ à superfície de partículas de sílica, que foram acondicionadas no interior de micro-colunas para HPLC. Após esta ligação, o sobrenadante de hibridoma foi colocado em contato com as 
partículas com vazão de aproximadamente $10 \mu \mathrm{L} \mathrm{min}{ }^{-1}$, possibilitando a interação entre as moléculas de $\operatorname{IgG}$ e as de Proteína L covalentemente imobilizadas na sílica. Finalmente, os extratos protéicos previamente purificados por WGA passaram pela coluna, seguido pela eluição final das proteínas ligadas com tampão glicina, pH 2,4. A Figura 3.10A ilustra a corrida cromatográfica onde se dá primeiramente a ligação do IgG (sobrenadante de hibridoma) à proteína $\mathrm{L}$ da superfície de sílica. A Figura 3.10B ilustra o cromatograma no qual ocorre a inserção de uma amostra extraída de gastrocnêmio de camundongo controle, seguida pela eluição das moléculas que ficaram seletivamente retidas no IgG da coluna. A Figura 3.10C é uma análise semelhante à ocorida na Figura 3.10B, porém com proteínas de gastrocnêmio de camundongo LARGE.

As frações I, II e III de cada corrida cromatográfica foram coletadas e quantificadas pelo método de BCA. Nas frações II, da Figura 3.10A (ligação do IgG), e III, das Figuras 3.10B e C, não foram detectadas proteínas, provavelmente porque o pico cromatográfico detectado pelo detector de UV estaria relacionado somente à mudança do tampão de eluição ocorrida neste momento da análise cromatográfica. A mudança de eluente é ilustrada pelas linhas marrom presentes nos cromatogramas (legenda “cond”). As demais frações que apresentaram alguma concentração de proteína foram digeridas com tripsina e analisadas por cLC-ESI-FTICR. A seguir, os dados de MS/MS foram pesquisados contra o banco de dados Swiss-Prot usando a ferramenta de busca Mascot (http://www.matrixscience.com). A busca foi realizada utilizando os seguintes parâmetros: Mus musculus para taxonomia, tripsina como enzima (máximo de uma clivagem perdida). Carbamidometilação de cisteína como modificação fixa e oxidação de metionina como modificação variável foram definidas. Tolerância de massa de íons precursor e fragmento foi de 2,0 e 0,8 Da, respectivamente. A carga de peptídeo monoisotópico foi definida como $2+$ e $3+$. As buscas resultaram numa lista de proterínas cujos resultados com valor de score acima de 37 eram significativos.

Nenhuma das frações analisadas apresentaram proteínas com score acima de 37. Entretanto, a proteína distroglicana (DAG1) foi apresentada na lista de busca das frações II, tanto da amostra controle quanto da amostra LARGE, com score 19 (com 2 peptídeos encontrados). Nas demais frações, esta proteína não foi foi listada, mesmo em valores de score abaixo do significativo.

Uma das possíveis razões para os baixos valores de score encontrados para a distroglicana é a interferência dos resíduos de açúcares na etapa de digestão, ocasionando uma 
clivagem incompleta dos peptídeos ou uma modificação da MM dos peptídeos detectados por MS, impedindo uma cobertura maior destas estruturas. Pensando nisso, uma alíquota de cada uma das frações (I, II e III) foram digeridas com PNGase F, mas os resultados de score não foram alterados. É importante salientar que esta glicoproteína possui também resíduos de Oglicanas, que não são digeridos por PNGase F, e talvez por isso que os resultados de identificação não foram afetados pela liberação de N-glicanas potencialmente presentes nas frações.

Uma outra causa desses resultados pode ser que a quantidade dessa glicoproteína isolada não tenha sido suficiente para uma cobertura adequada da sequência peptídica. Quanto a isso, uma alternativa pode ser o aumento da capacidade de ligação da coluna de imunoafinidade, através da mudança de suas dimensões.

Os resultados dessas análises iniciais de cromatografia de imunoafinidade podem ser futuramente melhoradas, através da realização de alguns ajustes, como tamanho da coluna, como já sugerido acima, vazões das fases móveis, entre outros, para que seja possível a purificação de quantidade suficiente de $\alpha$-DG necessária para uma subsequente identificação e análise dos resíduos de açúcares ligados a ela. Como será abordado no capítulo seguinte, o tecido muscular utilizado nos experimentos apresentou muitas impurezas difíceis de serem eliminadas, que acabaram prejudicando a detecção das glicanas por MS. Portanto, uma etapa adicional de purificação por esta metodologia, mesmo que a $\alpha$-DG não fique $100 \%$ pura, facilitará a comparação dos resíduos de açúcares presentes em proteínas de amostras doentes e sadias. 

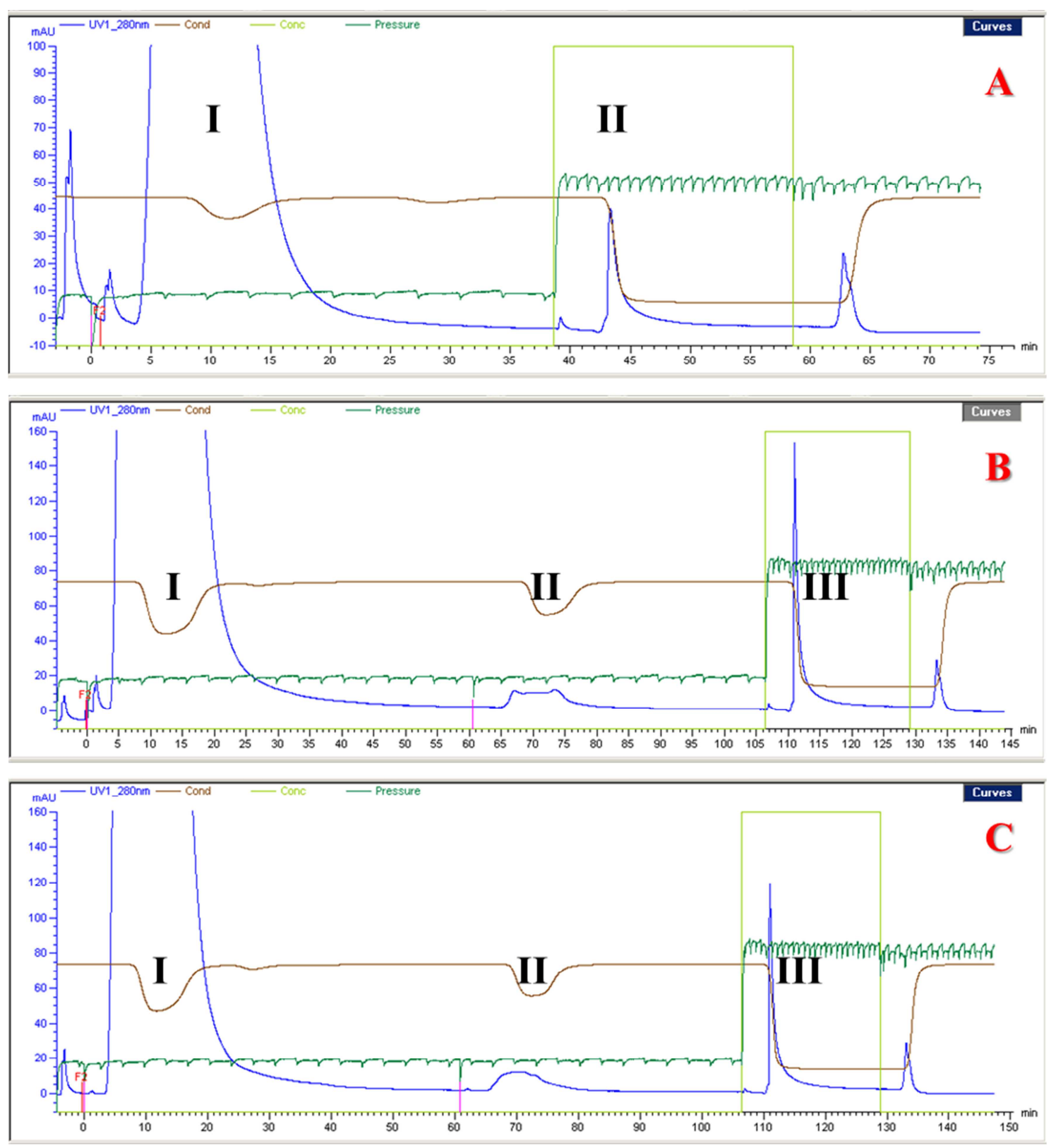

Figura 3.10 - Cromatografia de imunoafinidade. Anticorpo: sobrenadante de hibridoma sx/3/50/25 (IgG anti- $\alpha$ DG). A: ligação do IgG à proteína L presente na superfície da sílica. B: eluição das proteínas de amostra controle (gastrocnêmio de camundongo com 10 semanas de idade). C: eluição das proteínas de amostra doente (gastrocnêmio de camundongo LARGE com 10 semanas de idade). Evento I: impurezas presentes nas amostras; eluição com tampão PBS $0,1 \mathrm{~mol} \mathrm{~L}^{-1}, \mathrm{NaCl} 0,15$ mol L ${ }^{-1}, \mathrm{pH} 7,4$; vazão da fase móvel de $10 \mu \mathrm{L}$ min $^{-1}$. Evento II: detecção das proteínas retidas nas moléculas de $\mathrm{IgG}$, previamente imobilizadas no interior da coluna; mesma vazão e tampão de eluição utilizados durante o Evento I. Evento III: deteç̧ão das moléculas de $\mathrm{IgG}$ imobilizadas no interior da coluna; eluição com tampão glicina $0,1 \mathrm{~mol} \mathrm{~L}^{-1}$, $\mathrm{pH}$ 2,4; fluxo de 40 $\mu \mathrm{L} \min ^{-1}$. Legenda: linha azul: detector UV a $280 \mathrm{~nm}$. Linha marrom: detector condutividade. Linha verde-escuro: pressão. Linha verde-claro: composição da fase móvel. 


\subsection{Conclusão}

Através da técnica de immunoblotting foi possível observar diferenças entre amostras extraídas de animais com e sem mutações no gene LARGE. Diversos anticorpos anti $\alpha$-DG foram utilizados para detecção de isoformas glicosiladas (VIA4-1 e IIH6) e não glicosiladas (sx/3/50/25). Resultados de WB mostraram que a $\alpha$-DG de camundongos controle possuem MM maior do que de animais LARGE, porém sua cadeia polipeptídica é semelhante, pois o anticorpo sx/3/50/25 se ligou a proteínas de ambas as amostras. Estes resultados estão de acordo com dados da literatura, que sugerem que mutações no gene LARGE resultam na alteração do padrão de glicosilação da $\alpha$-DG, comprometendo sua capacidade de interação com o domínio laminina $\mathrm{G}$.

Embora foram encontradas diferenças significativas na estrutura da $\alpha$-DG, os resultados de WB não mostraram alterações na $\beta$-DG, que pode também ser purificada por WGA.

Os primeiros resultados de cromatografia de imunoafinidade apontam para a possibilidade do seu uso para um futuro isolamento de quantidades adequadas de $\alpha$-DG que viabilizem o estudo de suas estruturas glicânicas. 


\subsection{Bibliografia}

1. WESTERMEIER, R.; NAVEN, T.; HOPKER, H-R. Proteomics in practice: a guide to successful experimental design. $2^{\text {nd }}$ ed. Weinheim: Wiley-VCH, 2008.

2. WESTERMEIER, R. Electrophoresis in practice. $3^{\text {rd }}$ ed. Weinheim: Wiley-VCH, 2000.

3. GLASEL, J. A.; DEUTSCHER, M. P. Introduction to biophysical methods for protein and nucleic acid research. San Diego: Academic press, 1995.

4. TOWBIN, H.; STAEHLIN, T.; GORDON, J. Proceedings of the National Academy of Sciences of the United States of America, v.76, p.4350-4354, 1979.

5. ROSENBERG, I. M. Protein analysis and purification: benchtop techniques. $2^{\text {nd }}$ ed. Boston: Birkhäuser, 2005.

6. http://www.invitrogen.com/site/us/en/home/References/Molecular-Probes-TheHandbook/Technical-Notes-and-Product-Highlights/Antibody-Structure-andClassification.html. Acesso em: 18 de Janeiro de 2013.

7. KÖHLER, G.; MILSTEIN, C. Nature, v.256, p.495-497, 1975.

8. http://www.benchfly.com/blog/how-to-perform-a-semi-dry-transfer/. Acesso em: 21 de Janeiro de 2013.

9. http://www.uklabs-direct.co.uk/html/used_electrophoresis_equipment.html. Acesso em: 21 de Janeiro de 2013.

10. http://www.benchfly.com/profile-public.php?u=10. Acesso em: 21 de Janeiro de 2013.

11. http://commons.wikimedia.org/wiki/File:Western_blot_wet_transfer_system_Criterion06.jpg. Acesso em: 21 de Janeiro de 2013. 
12. SVOBODA, M.; MANN, B. F.; GOETZ, J. A.; NOVOTNY, M. V. Analytical Chemistry, v.84, p.3269-3277, 2012.

13. BARRESI, R.; CAMPBELL, K. P. Journal of Cell Science, v.119, p.199-207, 2005.

14. ERVASTI, J. M.; CAMPBELL, K. P. The Journal of Cell Biology, v.122(4), p.809-823, 1993.

15. YOSHIDA-MORIGUCHI, T.; YU, L.; STALNAKER, S. H.; DAVIS, S.; KUNZ, S.;

MADSON, M.; OLDSTONE, M. B. A.; SCHACHTER, H.; WELLS, L.; CAMPBELL, K. P. Science, v.327, p.88-92, 2010.

16. PAVONI, E.; SCIANDRA, F.; BARCA, S.; GIARDINA, B.; PETRUCCI, T. C.; BRANCACCIO, A. Febs Letters, v.579, p.493-499, 2005. 
Capítulo 4

\section{Glicômica de Tecidos}

Musculares de Modelos

Animais 


\subsection{Introdução}

Existem duas formas de estudar os padrões de glicosilação de proteínas. A primeira é usando-se enzimas deglicosilantes, que liberam as glicanas ligadas à cadeia polipeptídica. E posteriormente realiza-se uma separação e detecção apenas dos resíduos de açúcares liberados. ${ }^{1,2}$ Esta metodologia de estudo possui a vantagem de permitir que diferentes formas isoméricas de açúcares sejam distinguidas. Porém, uma informação valiosa é perdida, a sítioespecificidade das glicosilações.

Uma alternativa para não se perder este tipo de informação é clivar a glicoproteína intacta, isto é, com seus resíduos de açúcares ainda ligados. Para isso, utilizam-se enzimas conhecidas como endoproteases, que agem sobre a cadeia polipeptídica da glicoproteína, e a seguir procede-se a separação e detecção dos glicopeptídeos. ${ }^{3}$ Entretanto, a identificação por MS de glicopeptídeos numa amostra complexa de proteína digerida é sempre uma tarefa difícil por várias razões. Os glicopeptídeos geralmente constituem a menor porção da mistura de peptídeos totais. Seus sinais possuem intensidade relativamente menor, se comparado aos peptídeos não glicosilados, principalmente pelo fato de que seus sinais são distribuídos entre uma população de espécies com diferentes estruturas glicânicas, o que diminui a eficiência da ionização. Além disso, os sinais dos glicopeptídeos são suprimidos quando na presença de outros peptídeos, principalmente se o resíduo de oligossacarídeo possuir carga negativa, como no caso de ácidos siálicos. Por isso, o enriquecimento dos glicopeptídeos antes das análises é sempre recomendável, para melhorar os resultados de análise. ${ }^{4}$

As duas abordagens de estudo dos padrões de glicosilação são complementares, embora ambas possuam vantagens, desvantagens e também dificuldades de análise. Neste capítulo, porém, será enfatizado o estudo dos açúcares previamente liberados dos resíduos de peptídeos, e sua análise por MS.

Para obter os oligossacarídeos intactos e livres de seus peptídeos ligantes, existem métodos enzimáticos ou químicos para sua liberação, como mostra a Figura 4.1. No caso de $\mathrm{N}$-glicanas, existem duas enzimas (PNGase A e F) que, juntas, liberam todas as variedades de estruturas $\mathrm{N}$-glicosídicas existentes. O mesmo não ocorre com O-glicanas, pois existe uma variedade muito maior de ligações O-glicosídicas do que enzimas que atuam sobre este tipo de ligações, e as poucas enzimas que existem são altamente específicas, limitando a 
capacidade de digestão. Sendo assim, a estratégia geralmente escolhida para liberação das Oglicanas é por reações químicas. ${ }^{4,5}$

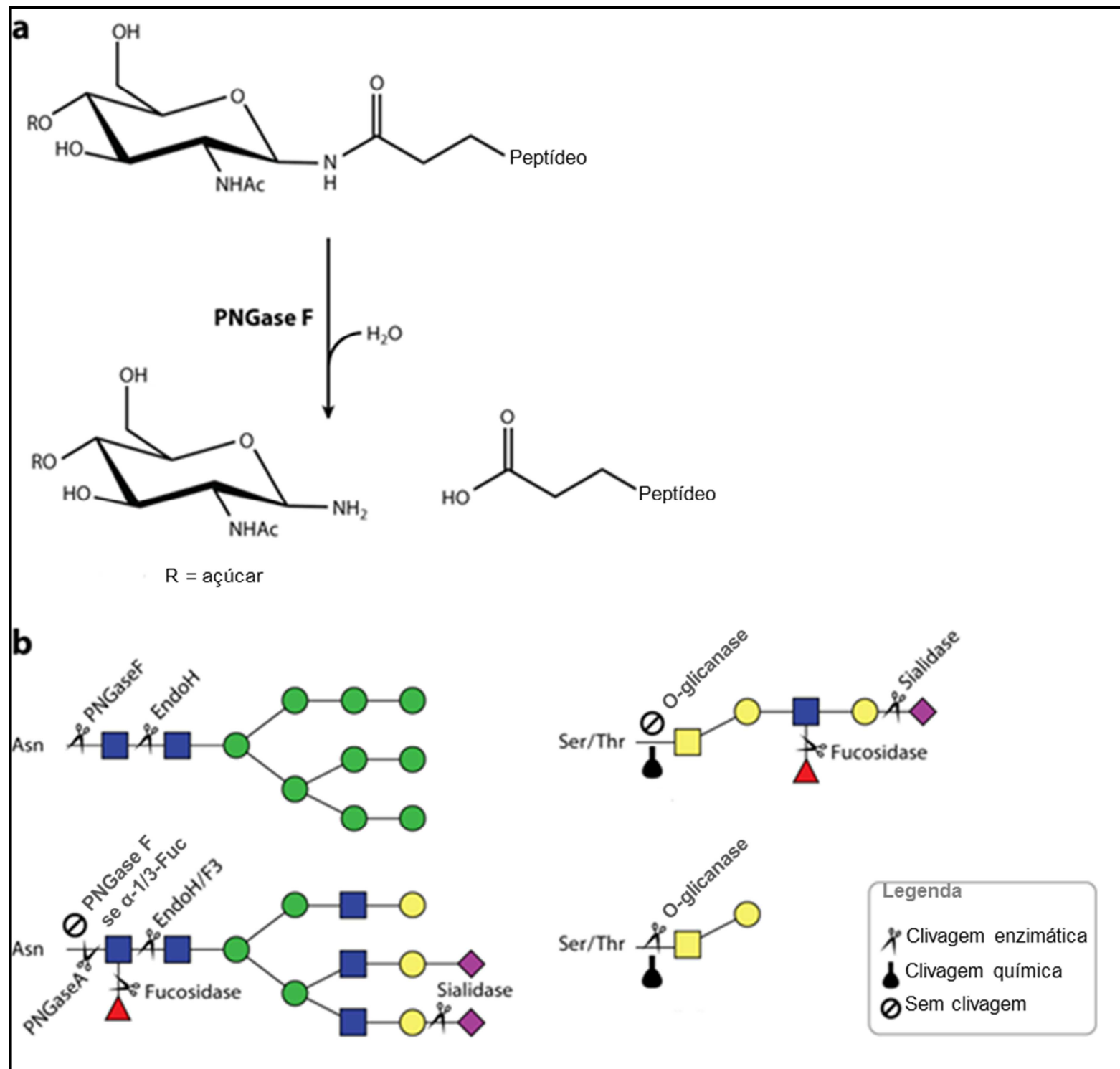

Figura 4.1 - Modos de digestão de oligossacarídeos ligados a proteínas. a: reação de digestão com PNGase F. b: sítios de clivagem de enzimas e reações químicas. ${ }^{6}$

O êxito no estudo de glicanas livres baseia-se na otimização do preparo e da ionização destas estruturas. Os oligossacarídeos liberados enzimaticamente ou por métodos químicos não redutores possuem estruturas redutoras que permanecem em equilíbrio entre sua forma cíclica hemiacetal e aldeídos de cadeia aberta (Esquema 4.1). A redução de todas as formas em equilíbrio para uma única forma alditol previne a separação das glicanas redutoras em 
diferentes formas anoméricas. Por sua vez, a permetilação dos já alditóis gera estruturas muito mais estáveis, mais voláteis e mais informativas que as nativas quando analisadas por MS. ${ }^{7}$
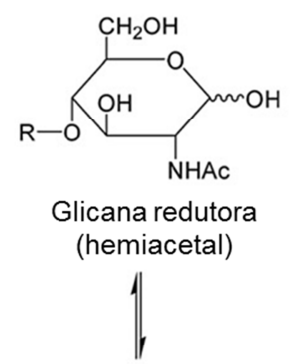

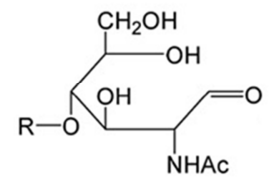

Glicana redutora (aldeído)

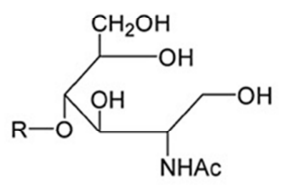

Glicana alditol

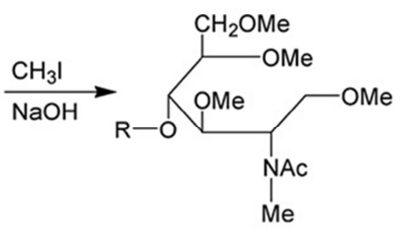

Glicana alditol permetilada

Esquema 4.1 - Estruturas glicânicas nativas e derivatizadas. ${ }^{7}$

O estudo do perfil de glicosilação das proteínas presentes numa determinada amostra pode ser realizado por meio de técnicas bioanalíticas diferentes, dentre as quais estão incluídas MALDI-MS, técnicas de separação como HPLC, cromatografia líquida capilar (cLC), eletrocromatografia capilar (CEC), eletroforese em capilar (CE) e em microchips (MCE), acopladas a MALDI-MS, ESI-MS ou a detectores de fluorescência induzida a laser (LIF). ${ }^{1,2,8}$

A técnica de MALDI-MS permite a análise de glicanas ácidas e neutras simultaneamente (dependendo da otimização de preparo de amostra e matriz utilizada), sendo possível fazer um mapeamento glicômico de um indivíduo e compará-lo com outros perfis glicômicos. Porém, esta abordagem não permite a distinção entre as diferentes formas isoméricas dos oligossacarídeos, a não ser que se realize um isolamento prévio ou uma separação on-line dos mesmos. ${ }^{2} \mathrm{O}$ uso de exoglicosidases específicas para determinadas configurações de ramificações é também uma alternativa para a obtenção de maiores informações estruturais. ${ }^{9}$

MALDI-MS gera espectros simples mesmo com uma mistura complexa de oligossacarídeos, pois geralmente não produz íons com múltiplas cargas ou fragmentados. Se a amostra for preparada corretamente, os espectros de MALDI-MS geram sinais cuja intensidade podem ser relacionadas à concentração relativa da espécie na amostra. ${ }^{4}$ 
Existem diferentes matrizes disponíveis para ionização de açúcares por MALDI. Sua escolha correta é de extrema importância, pois algumas são eficientes para algumas estruturas e ineficientes para outras. A matriz mais comumente utilizada para oligossacarídeos é o ácido 2,5-dihidroxibenzóico (DHB). Diversos trabalhos publicados na literatura mostram que é possível também obter ganhos de sensibilidade ou resolução com a mistura de diversos outros compostos ao 2,5-DHB. ${ }^{10}$

Atualmente existem algumas ferramentas de software e bibliotecas online que podem ser utilizadas para atribuição da estrutura e composição dos oligossacarídeos numa amostra. Uma destas ferramentas é a GlycoMod (http://expasy.ch/tools/glycomod/), projetada para encontrar todas as composições de glicanas e glicopeptídeos teóricos possíveis, através de comparação com os íons observados no espectro de massas. A GlycoMod pode ser utilizada com sucesso para glicanas livres ou derivatizadas de carga única, como os íons gerados por MALDI. $^{11}$ 


\subsection{Objetivos}

Os principais objetivos deste estudo foram:

- desenvolver uma metodologia de preparo de amostra e análise de oligossacarídeos isolados de glicoproteínas de músculo estriado de camundongos.

- caracterizar as estruturas das glicanas por MS, visando uma futura comparação entre amostras de camundongos controle e LARGE. 


\subsection{Experimental}

Para o estudo específico dos resíduos de oligossacarídeos isolados das glicoproteínas, foi necessário testar diversas metodologias de preparo de amostra, incluindo: diferentes tampões para extração e homogeneização das proteínas, e os modos de clivagem dos resíduos de açúcares, em especial das O-glicanas, que foi realizada por reação química e não por enzimas, além das etapas de purificação dos oligossacarídeos.

No entanto, somente serão apresentados os procedimentos que proporcionaram os melhores resultados conseguidos com amostras de músculo. Desta forma, os dados apresentados neste capítulo foram obtidos de acordo com a metodologia detalhada a seguir.

\subsubsection{Extração, processamento e purificação das glicoproteínas}

As amostras escolhidas para análise glicômica foram gastrocnêmios de camundongos com idade entre 8 e 12 semanas. Estes animais foram sacrificados e seus músculos extraídos e processados seguindo o protocolo apresentado no capítulo 2, seção 2.3.1. Somente a composição do tampão de extração das proteínas foi modificada. Conforme será discutido a seguir, algumas alterações foram necessárias no tampão para a obtenção de melhores resultados de MS.

Resumidamente, os músculos foram homogeneizados, com o auxílio de um ruptor de tecidos, na presença de tampão para a extração e solubilização das proteínas. Após um intervalo de agitação, os tubos contendo as amostras foram centrifugados a $10000 \mathrm{rpm}$ por 15 min a $4{ }^{\circ} \mathrm{C}$, para a separação entre precipitado (descartado) e sobrenadante (contendo as proteínas).

O sobrenadante foi fracionado numa coluna de WGA, e as glicoproteínas foram, em seguida, dialisadas e liofilizadas pelos mesmos procedimentos descritos no capítulo 2, seção 2.3.4. A quantificação das glicoproteínas foi feita pelo método de BCA. 


\subsubsection{Digestão das N-glicanas e purificação}

Cerca de $50 \mu \mathrm{g}$ de glicoproteínas purificadas por WGA foram diluídas em $20 \mu \mathrm{L}$ de solução tampão fosfato de sódio $10 \mathrm{mmol} \mathrm{L}^{-1} \mathrm{pH} 7,4$, contendo $0,1 \% \operatorname{SDS}(\mathrm{m} / \mathrm{v})$ e $0,1 \% \beta$ mercaptoetanol (v/v). As glicoproteínas foram incubadas nesse tampão por $1 \mathrm{~h}$ a $60{ }^{\circ} \mathrm{C}$. Após este período, a solução foi resfriada e adicionou-se NP-40 a uma concentração final de $1 \%$ (v/v). Uma alíquota de $5 \mathrm{mU}$ de PNGase $\mathrm{F}$ foi adicionada à mistura reacional, e incubada a 37 ${ }^{\circ} \mathrm{C}$ por $18 \mathrm{~h}$. Terminado o período de incubação, as glicanas foram purificadas em colunas para centrífuga, primeiramente por C18 e em seguida por carbono grafite.

Para as colunas de C18, foram empregados os seguintes eluentes:

- pré-lavagem: 3 lavagens de $400 \mu \mathrm{L}$ cada com 15:85:0,1 água/ACN/TFA;

- condicionamento e eluição das N-glicanas: 3 lavagens de $400 \mu \mathrm{L}$ cada para condicionamento e 2 lavagens de $100 \mu \mathrm{L}$ cada para eluição, com 95:5:0,1 água/ACN/TFA.

Para as colunas contendo carbono grafite, foram empregados os seguintes eluentes:

- pré-lavagem: 3 lavagens de $400 \mu \mathrm{L}$ cada com 15:85:0,1 água/ACN/TFA;

- condicionamento e lavagem de interferentes: 3 lavagens de $400 \mu \mathrm{L}$ cada para condicionamento e 2 lavagens de $200 \mu \mathrm{L}$ cada para eluição dos interferentes, com 95:5:0,1 água/ACN/TFA;

- eluição das N-glicanas: $200 \mu \mathrm{L}$ de solução 75:25:0,1 água/ACN/TFA. 


\subsubsection{Redução e permetilação das N-glicanas}

Para reduzir as N-glicanas, foi adicionado a cada amostra $10 \mu \mathrm{L}$ de solução $10 \mathrm{mg}$ $\mathrm{mL}^{-1}$ de complexo amônia borano $\left(\mathrm{H}_{3} \mathrm{~N}-\mathrm{BH}_{3}\right.$, carreador de $\mathrm{H}$ que promove a abertura dos anéis dos oligossacarídeos) em água, incubando por $1 \mathrm{~h}$ a $60^{\circ} \mathrm{C}$. $\mathrm{O}$ excesso de complexo amônia borano foi destruído com a adição de 2 alíquotas de $20 \mu \mathrm{L}$ de ácido acético $10 \%$, com intervalos de $1 \mathrm{~h}$.

A mistura reacional foi a seguir seca em centrífuga a vácuo e os íons B residuais $\left(\mathrm{B}\left(\mathrm{CH}_{3}\right)_{3}\right)$ foram removidos por evaporação pela adição consecutiva de 3 alíquotas de $100 \mu \mathrm{L}$ de metanol. A seguir, os açúcares reduzidos e secos foram permetilados.

Para permetilação, foi adicionado a cada vial com amostra $5 \mu \mathrm{L}$ de água, $70 \mu \mathrm{L}$ de dimetilformamida (DMF) e $25 \mu \mathrm{L}$ de iodeto de metila. A mistura foi adicionada a colunas de centrífuga preenchidas com partículas de $\mathrm{NaOH}$ previamente lavadas com ACN e DMF. Após a adição das amostras, cada coluninha ficou imóvel por 15 min. Terminado o período de incubação, as coluninhas foram centrifugadas, e às soluções eluídas foi adicionado mais 25 $\mu \mathrm{L}$ de iodeto de metila. As misturas foram novamente inseridas em suas respectivas colunas, deixadas em repouso por mais 15 min e eluídas por centrifugação mais uma vez. A seguir, cada coluninha com suas partículas de $\mathrm{NaOH}$ foi lavada duas vezes com $100 \mu \mathrm{L}$ de ACN, e a solução de lavagem de cada amostra foi misturada a seus respectivos eluídos.

Finalmente, as glicanas permetiladas foram particionadas com clorofórmio e água. A fase orgânica contendo as N-glicanas foram secas, diluídas com $10 \mu \mathrm{L}$ de 50:50 v/v água/metanol, e aplicadas às placas de MALDI. A matriz utilizada foi uma solução de DHB $10 \mathrm{mg} \mathrm{mL}^{-1}$ contendo $1 \mathrm{mmol} \mathrm{L}^{-1}$ de acetato de sódio. Os espectros de MALDI-MS das glicanas foram adquiridos no modo positivo reflectron, utilizando o instrumento de MALDI TOF/TOF da Applied Biosystems 4800, e os dados foram processados usando o Software DataExplorer 4.0. 


\subsubsection{Digestão das O-glicanas}

O procedimento de digestão das O-glicanas que gerou resultados mais promissores de MS foi o seguinte. Uma alíquota de $25 \mu \mathrm{g}$ de glicoproteínas extraídas e purificadas por WGA foram diluídas em $20 \mu \mathrm{L}$ de água mili-Q contendo $1 \%$ de $\beta$-mercaptoetanol. Cada frasco contendo essa solução foi então incubada a $60{ }^{\circ} \mathrm{C}$ por $1 \mathrm{~h}$. A seguir, foi adicionada Pronase A a uma concentração final de $2,5 \mu \mathrm{g} \mu \mathrm{L}^{-1}$, e a digestão ocorreu a $55^{\circ} \mathrm{C}$ por $48 \mathrm{~h}$.

Terminada a digestão, a mistura reacional foi seca e, logo após, permetilada da mesma maneira que as $\mathrm{N}$-glicanas. Finalmente, as $\mathrm{O}$-glicanas foram particionadas com clorofórmio e água, secas em centrífuga, diluídas com $10 \mu \mathrm{L}$ de 50:50 v/v água/metanol, e aplicadas às placas de MALDI. A matriz utilizada foi o DHB $10 \mathrm{mg} \mathrm{mL}^{-1}$ contendo $1 \mathrm{mmol} \mathrm{L}^{-1}$ de acetato de sódio.

Os espectros de MALDI-MS das O-glicanas foram também adquiridos no modo positivo reflectron, e os dados foram processados usando o Software DataExplorer 4.0. 


\subsection{Resultados e discussão}

Para a otimização do preparo das amostras de açúcares foram utilizados diferentes tampões para extração e solubilização das proteínas dos tecidos. Verificou-se que o uso de Triton X-100, apesar de auxiliar na extração e solubilização de proteínas de membrana (sendo uma delas a $\beta$-DG, detectada nos experimentos de WB), prejudicou significativamente o processo de ionização por MALDI mesmo após todas as etapas de limpeza empregadas com as amostras. Isto se deve ao fato de a estrutura molecular do Triton X-100 permitir uma fácil ionização pela técnica utilizada, resultando na supressão de íons de interesse da amostra. ${ }^{12}$

Outros detergentes também foram testados no tampão de amostra, como SDS, CHAPS e NP-40, porém os melhores resultados finais das análises foram obtidos através do emprego do tampão preparado com os reagentes da Tabela 2.1, mas sem a adição de qualquer detergente. Para verificar se a $\alpha-D G$ estava presente no grupo de glicoproteínas extraídas com este tampão, foi realizada previamente uma análise de WB dessas amostras. Foi visualizada uma banda em torno de $156 \mathrm{kDa}$ na membrana, à qual o anticorpo IIH6 se ligou seletivamente. Tendo a certeza da presença da $\alpha$-DG junto às outras glicoproteínas extraídas, os resultados obtidos das análises dos oligossacarídeos incluiriam também os resíduos presentes nesta glicoproteína, que foi a idéia inicial do experimento.

Estabelecida a composição do tampão de amostra, e após a purificação das glicoproteínas por WGA, partiu-se para o desenvolvimento do protocolo de digestão das glicanas $\mathrm{N}$ - e O-ligadas.

No caso das N-glicanas, a digestão ocorreu enzimaticamente com o uso de PNGase F. Para separar os oligossacarídeos já clivados das demais impurezas presentes nas amostras finais, como sais, detergentes, peptídeos e proteínas, foram testadas as seguintes metodologias de purificação das N-glicanas:

1. extração em fase sólida somente com fase C-18.

2. extração em fase sólida somente com carvão ativado.

3. extração em fase sólida somente com fase amino.

4. extração em fase sólida com fase C-18 e carvão ativado.

5. extração em fase sólida com fase C-18 e amino. 
Em conjunto com as diferentes fases sólidas empregadas para a purificação dos oligossacarídeos $\mathrm{N}$-ligados, diferentes sistemas de solventes foram aplicados em conjunto, visando os melhores resultados de MS. Mas, apesar das várias estratégias aplicadas, vários íons concomitantes continuaram presentes nos espectros, e os sinais característicos de açúcares foram detectados em baixas intensidades. No entanto, os resultados mais promissores conseguidos foram com amostras preparadas seguindo os procedimentos detalhados na seção 4.3 deste capítulo, isto é, com o uso de coluninhas de C18 e posteriomente de colunas de carvão ativado para a purificação das N-glicanas.

Um dos espectros de massas obtidos com a análise das $\mathrm{N}$-glicanas permetiladas está ilustrado na Figura 4.2. As estruturas ilustradas acima dos seus respectivos sinais foram propostas com base nas razões $\mathrm{m} / \mathrm{z}$ dos íons detectados, utilizando a base de dados Expazy http://web.expasy.org/glycomod/ e levando em conta dados teóricos das estruturas já encontradas em camundongos. Diversos picos presentes no espectro de MS não corresponderam a nenhum valor de $\mathrm{m} / \mathrm{z}$ de $\mathrm{N}$-glicanas conhecidas e presentes no banco de dados Expazy, e portanto estes íons foram considerados como interferentes não eliminados durante o preparo de amostra. Todavia, visto a enorme variabilidade de estruturas possíveis, em conjunto com a falta de conhecimento sobre tais estruturas nos leva a pensar que tais sinais sejam novas estruturas glicanas, as quais necessitariam um estudo sistemático de elucidação estrutural sobre elas. Infelizmente, não foi possível realizar experimentos de MSMS para confirmar as estruturas dos íons detectados devido à baixa intensidade daqueles sinais de estruturas presentes na base de dados.

Como pode ser verificado pela Figura 4.2, as estruturas propostas possuem resíduos de $\mathrm{N}$-acetilglucosamina e de ácido siálico. A lectina WGA, escolhida para purificação das glicoproteínas, reconhece esses resíduos de açúcares, tanto em forma de dímeros e trímeros, quanto em regiões terminais. ${ }^{13}$ Portanto, apesar dos experimentos de MS/MS não terem sido feitos, existe uma grande possibilidade de as estruturas propostas estarem corretas ou serem bastante semelhantes à real. 


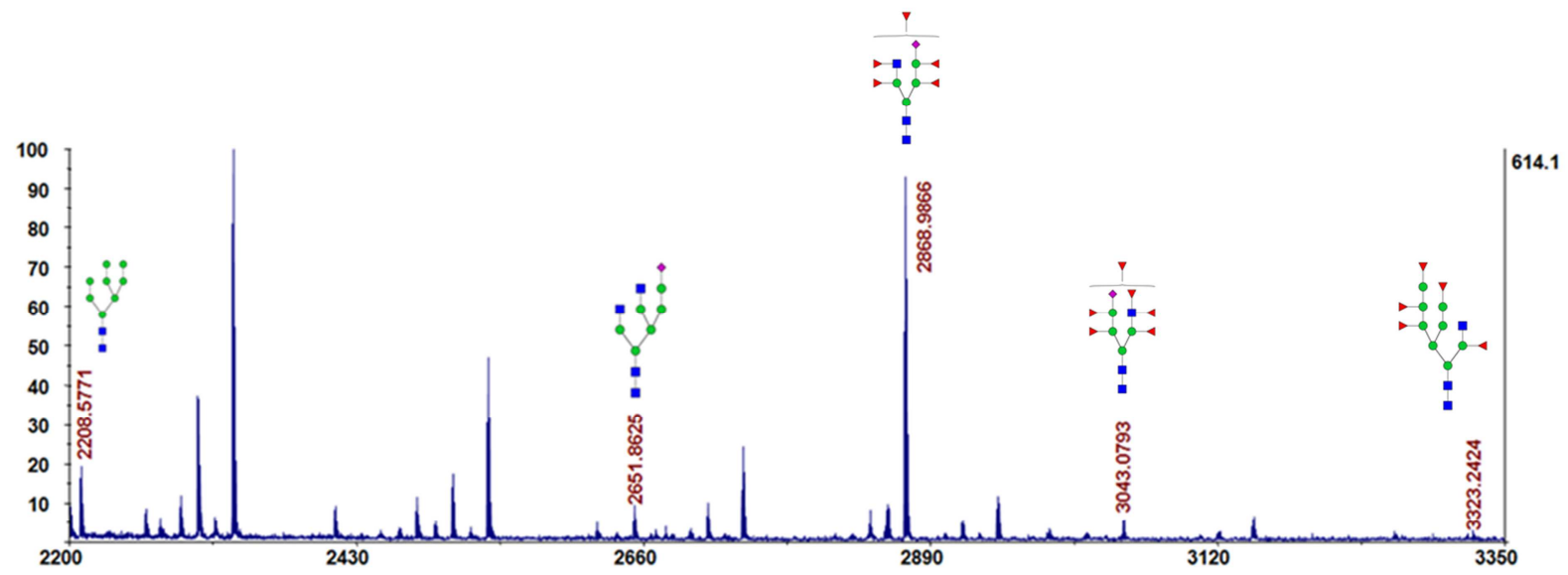

Figura 4.2 - Espectro de massas por MALDI-TOF no modo positivo reflectron. N-glicanas extraídas de glicoproteínas presentes em gastrocnêmio de camundongo controle. Amostras foram digeridas com PNGase F e permetiladas em fase sólida. Legenda: ( $\square$ )N-acetilglucosamina. (O)Manose. ( $\Delta$ ) Fucose. $(\diamond)$ Ácido N-acetilneuramínico.

Em relação às O-glicanas, a ausência de uma enzima capaz de clivar ligações entre estes açúcares e a cadeia protéica, seja qual for a estrutura do açúcar e do peptídeo em questão, requereu o uso de reações químicas para sua liberação. Foram testadas três metodologias de digestão: eliminação- $\beta$ com hidróxido de sódio e borohidreto de sódio, ${ }^{14}$ eliminação- $\beta$ com amônia ${ }^{15}$ e digestão com pronase seguida por uma reação de permetilação em fase sólida. ${ }^{16}$ As duas primeiras metodologias resultaram em espectros de MS sem qualquer íon com valor sinal/ruído satisfatório. Já através da digestão inicial da cadeia peptídica com pronase, seguida pela clivagem da ligação peptídeo-açúcar durante a reação de permetilação, alguns picos característicos de O-glicanas foram detectados, como pode ser verificado na Figura 4.3.

Pronase (Roche) é uma protease não específica que cliva as cadeias peptídicas gerando aminoácidos individuais, dada a sua baixa especificidade. Por esta razão, ela é uma ferramenta para a análise glicômica de glicoproteínas, possibilitando a ruptura de toda sua estrutura tridimensional, facilitando assim a exposição das ligações peptídeo-açúcar para a reação de clivagem. Esta clivagem, por sua vez, ocorreu, no experimento, por uma reação química, e não enzimática. Acredita-se que o meio altamente básico que foi empregado para a permetilação dos açúcares também favoreceu a reação de eliminação- $\beta$, liberando as glicanas ligadas a resíduos de serina ou treonina, conforme o Esquema 4.2 proposto por Goetz et al. ${ }^{16}$ 


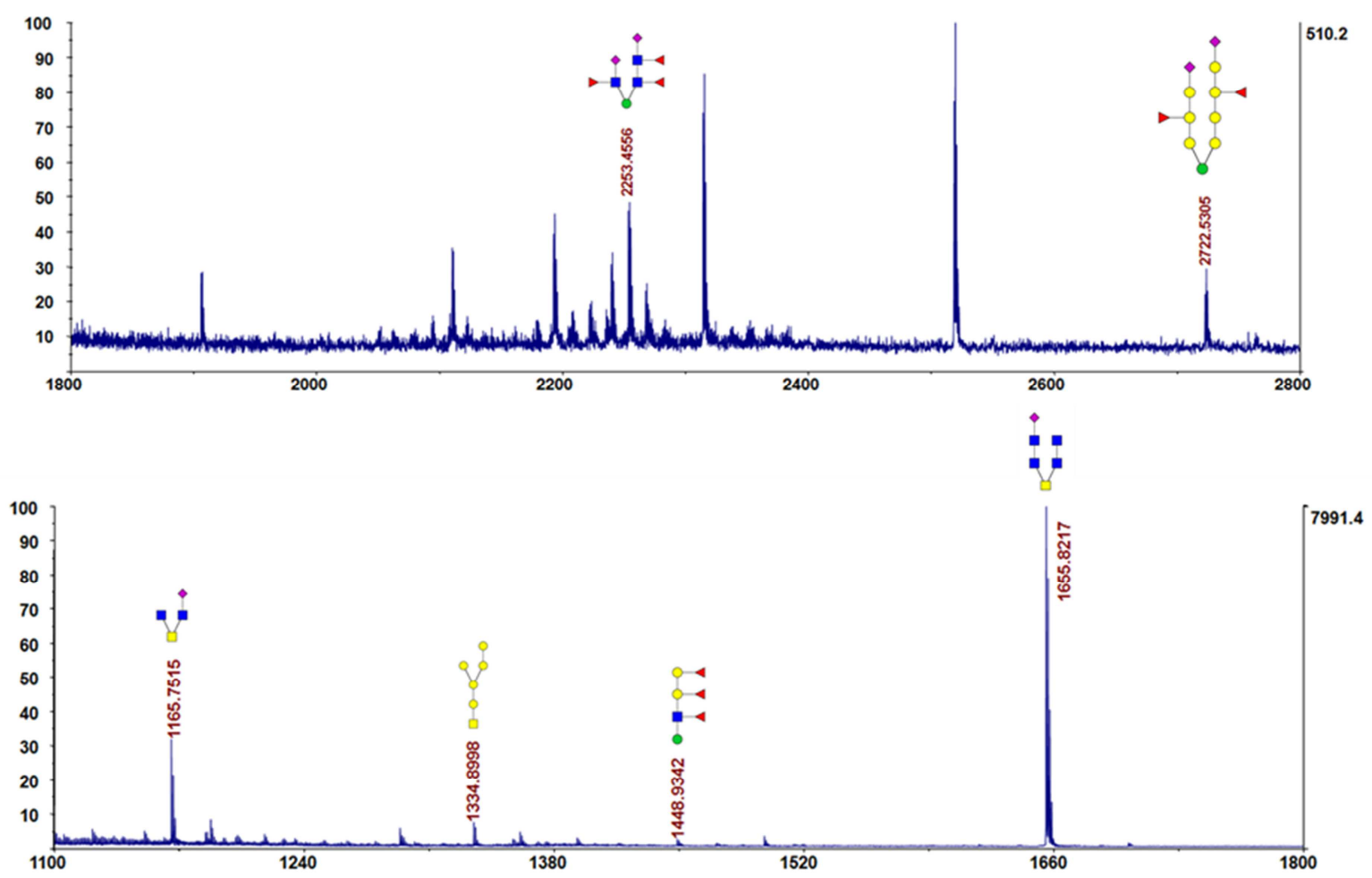

Figura 4.3 - Espectro de massas por MALDI-TOF no modo positivo reflectron. O-glicanas extraídas de glicoproteínas presentes em gastrocnêmio de camundongo controle. Amostras foram digeridas com Pronase e permetiladas em fase sólida. Legenda: (ロ) N-acetilglucosamina. ( $\square$ ) Nacetilgalactosamina. (O) Manose. (\) Fucose. $(\bigcirc)$ Galactose. $(\diamond)$ Ácido N-acetilneuramínico.
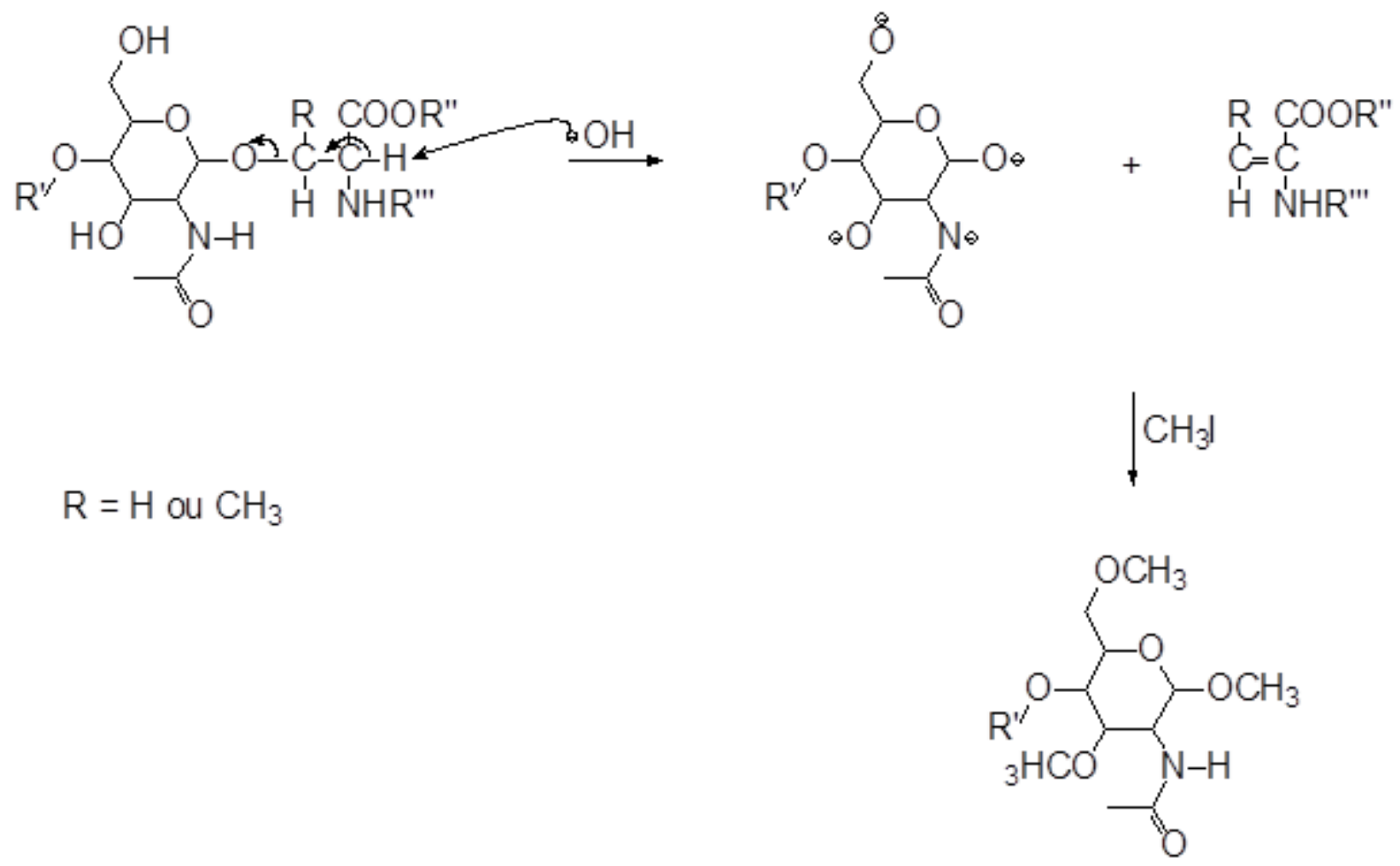

Esquema 4.2 - Reação de hidrólise básica de O-glicanas para um aminoácido isolado. ${ }^{16}$ 
O emprego desta metodologia de clivagem das O-glicanas utilizando pronase e eliminação- $\beta$ concomitante à reação de permetilação, conforme descrita na seção 4.3.4, havia sido realizada com sucesso apenas para digestão de glicoproteínas modelo comerciais, como fetuína e $\operatorname{IgA}{ }^{16}$ Apesar de os primeiros resultados obtidos para amostras provenientes de músculo ainda apresentarem íons concomitantes e sinais de interesse com baixa intensidade, como mostrado na Figura 4.3, eles representam um passo em avanço à obtenção de informações inéditas a respeito das estruturas de oligossacarídeos características deste tipo de amostra.

Aliando uma metodologia de isolamento e purificação específica da $\alpha$-DG a um protocolo adequado de digestão e purificação de seus resíduos de açúcares, será possível contribuir para um entendimento da relação que estas estruturas têm com a mutação no gene LARGE, pela comparação entre animais doentes e sadios. 


\subsection{Conclusão}

Glicoproteínas extraídas de gastrocnêmio de camundongos C57Black6 com idade entre 8 e 12 semanas, e purificadas por WGA, foram alvo de estudo glicômico. A digestão enzimática dessas glicoproteínas por PNGase F possibilitou a liberação de algumas estruturas glicânicas, que foram detectadas por MALDI-TOF. Apesar de os espectros gerados possuírem alguns picos que não puderam ser atribuídos a açúcares, e mesmo com a impossibilidade de se realizar experimentos de MS-MS, devido à baixa intensidade dos íons de interesse, as estruturas propostas condizeram com os tipos de açúcares que interagem com a WGA.

Para a liberação das O-glicanas, foi utilizada uma metodologia de digestão inicial com pronase, seguida por uma reação química de eliminação- $\beta$ específica dos açúcares O-ligados. Diversos íons concomitantes foram também detectados nos espectros de MS destas amostras, além de baixa intensidade dos sinais de interesse (glicanos com MM em bases de dados).

Os resultados observados sugerem a necessidade de uma otimização do preparo de amostra, visando a obtenção de espectros mais limpos e com sinais intensos, sendo possível assim a realização de experimentos de MS-MS, para elucidação das estruturas encontradas. 


\subsection{Bibliografia}

1. NOVOTNY, M. V.; SOINI, H. A.; MECHREF, Y. Journal of Chromatography B, v.866, p.26-47, 2008.

2. ZHANG, Y.; GO, E. P.; DESAIRE, H. Analytical Chemistry, v.80, p.3144-3158, 2008.

3. PLAVINA, T.; WAKSHULL, E.; HANCOCK, W. S.; HINCAPIE, M. Journal of Proteome Research, v.6, p.662-671, 2007.

4. GEYER, H.; GEYER, R. Biochimica et Biophysica Acta, v.1764, p.1853-1869, 2006.

5. BROOKS, S. A. Molecular Biotechnology, v.43, p.76-88, 2009.

6. RAKUS, J. F.; MAHAL, L. K. Annual Review of Analytical Chemistry, v.4, p.367-392, 2011.

7. ZAIA, J. Chemistry \& Biology, v.15, p.881-892, 2008.

8. ORAZINE, C. I.; HINCAPIE, M.; HANCOCK, W. S.; HATTERSLEY, M.; HANKE, J. H. Journal of Proteome Research, v.7, p. 1542-1554, 2008.

9. MORELlE, W.; MICHALSKI, J.-C. Current Analytical Chemistry, v.1, p.29-57, 2005.

10. HARVEY, D. J. Mass Spectrometry Reviews, v.18, p.349-451, 1999.

11. GO, E. P.; REBECCHI, K. R.; DALPATHADO, D. S.; BANDU, M. L.; ZHANG, Y.; DESAIRE, H. Analytical Chemistry, v.79, p.1708-1713, 2007.]

12. ZHANG, N.; LI, L. Rapid Communications in Mass Spectrometry, v.18, p.889-896, 2004. 
13. NAGATA, Y.; BURGER, M. M. The Journal of Biological Chemistry, v.240, p.31163122, 1974.

14. CARLSON, D. M. The Journal of Biological Chemistry, v.243, p.616-626, 1968.

15. HUANG, Y.; KONSE, T.; MECHREF, Y.; NOVOTNY, M. V. Rapid Communications in Mass Spectrometry, v.16, p.1199-1204, 2002.

16. GOETZ, J. A.; NOVOTNY, M. V.; MECHREF, Y. Analytical Chemistry, v.81, p.95469552, 2009. 
Anexo 


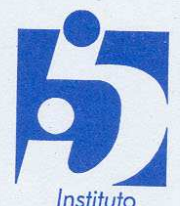

de Biociências

\section{$\frac{\text { UNIVERSIDADEDESÃOPAULO }}{\text { INSTITUTODE BIOCIENNCIAS }}$}

OF.CEA/IB/048/2008

Ref. 2008.1.1028.41.2

São Paulo, 06 de agosto de 2008.

Prezada Senhora

Dirijo-me a V. Sa. para informar que a Comissão de Ética em Uso de Animais Vertebrados em Experimentação do IB, em reunião realizada no dia 31/07/2008, APROVOU o Projeto "Avaliação da via de glicosilação da $\alpha$-distroglicana na formação e manutenção do Complexo Distrofina-Glicoproteínas associadas e sua relação com o músculo normal e distrófico" - Protocolo 075/2008, de sua responsabilidade.

Atenciosamente.

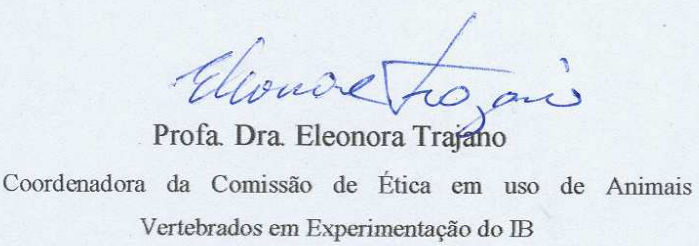

Ilma. Sra.

Profa. Dra. MARIZ VAINZOF

Departamento de Genética e Biologia Evolutiva do IBUSP

Rua do Matão - Travessa 14 n³21 - CEP 05508-900 - Cidade Universitária São Paulo - Brasil - hHto://www.ib.uso.br 